Szörényi András

A nem állami szereplők befolyásának növekedése a nemzetközi kapcsolatok különböző területein 


\section{Világgazdasági Tanszék}

Témavezető:

Horváth Jenő, Dr. habil.

Egyetemi magántanár

A Bíráló Bizottság névsora:

(C) Szörényi András 


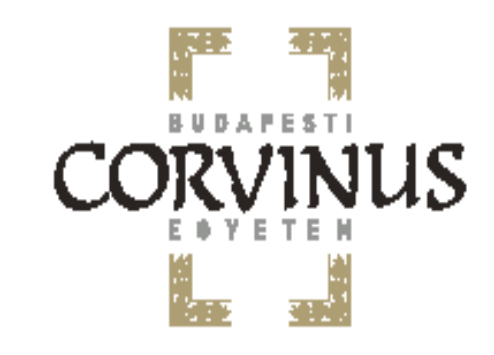

Nemzetközi Kapcsolatok

Doktori Iskola

A nem állami szereplők befolyásának növekedése a nemzetközi kapcsolatok különböző területein

Ph.D. értekezés

Szörényi András

Budapest, 2014 



\section{TARTALOMJEGYZÉK}

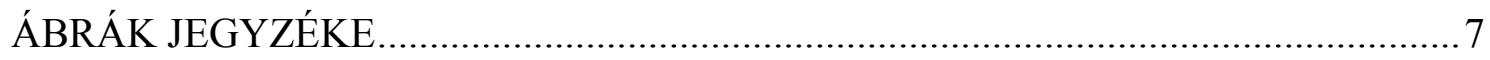

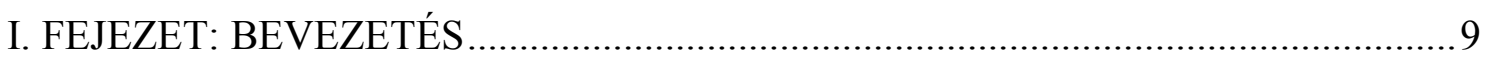

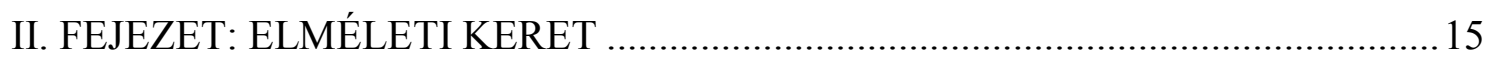

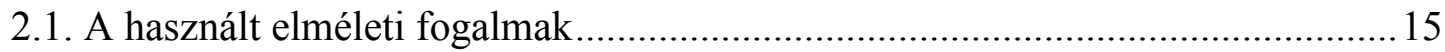

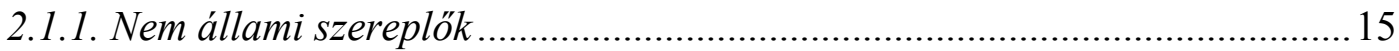

2.1.2. Transznacionális kapcsolatok vs. nemzetközi kapcsolatok ...........................19

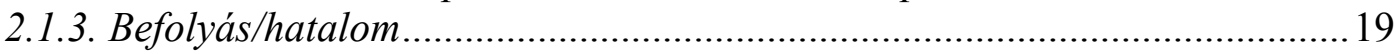

2.2. A nemzetközi kapcsolatok jelenlegi keretei..........................................................20

2.2.1. A nem állami szereplök térnyerése ………………………………….........23

2.3. A nemzetközi kapcsolatok vonatkozó elméletei ..................................................28

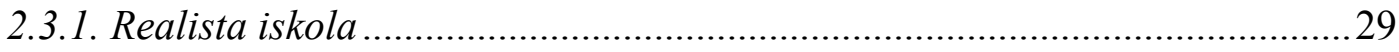

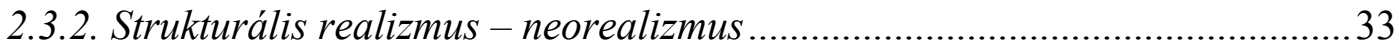

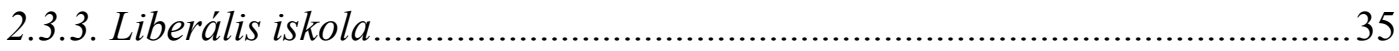

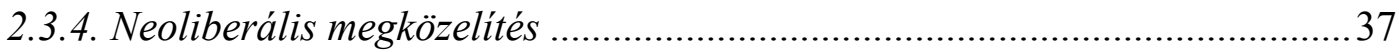

2.3.5. Transznacionális kapcsolatok 2.0 .............................................................. 40

III. FEJEZET: A NEMZETKÖZI KAPCSOLATOK VÁLTOZÁSAI ………………....48

3.1. A határok megváltozása .................................................................................. 48

3.2. A hatalom gyakorlásának változása ………………………………………........5

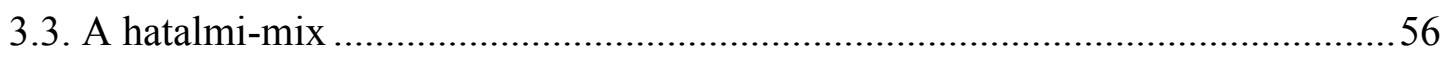

3.4. Alkalmazkodási kényszer …………………………………………………....58

IV. FEJEZET: A NEM ÁLLAMI SZEREPLÖK MEGNÖVEKEDETT

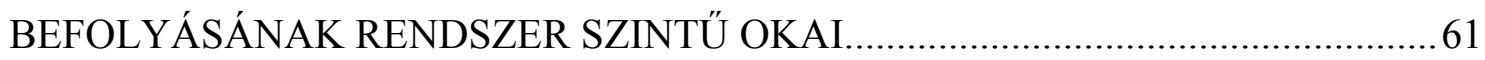

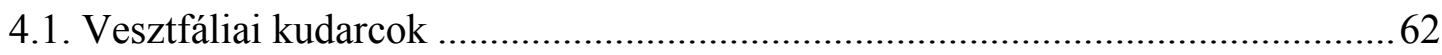

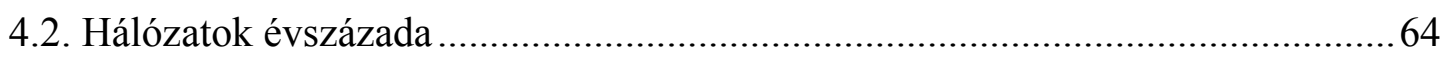

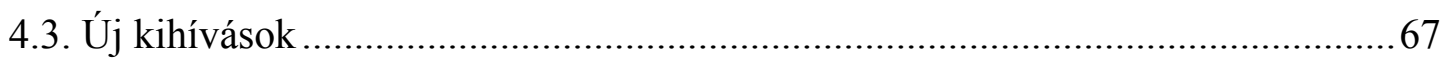

4.4. A nem állami szereplök relatív hatalmának növekedése ......................................68

V. FEJEZET: A NEM ÁLLAMI SZEREPLŐK ÉRDEKÉRVÉNYESÍTÉSÉNEK FORMÁI - AZ INTERAKCIÓK SZINTJEI .............................................................. 71

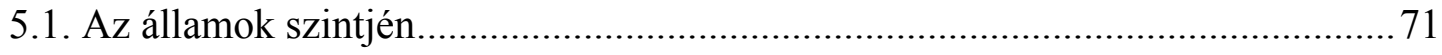

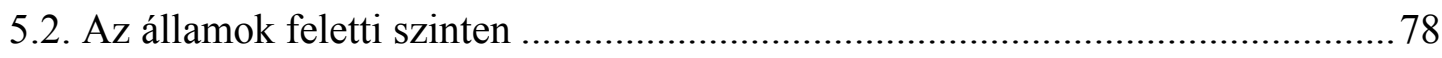

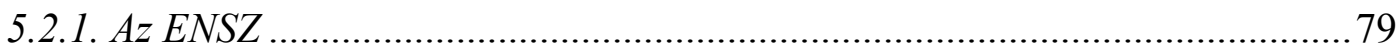

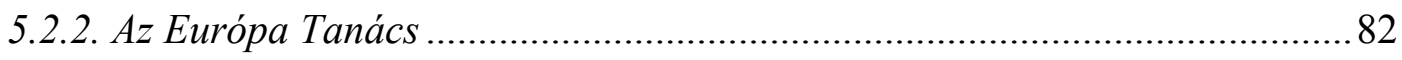


5.2.3. Az Európai Unió

5.3. Más nem állami szereplőkkel szemben

VI. FEJEZET: A NEM ÁLLAMI SZEREPLŐK ADOTTSÁGAINAK VÁLTOZÁSA

6.1. Képességek változása. 91

6.2. A befolyás növekedése egyes területeken....................................................... 94

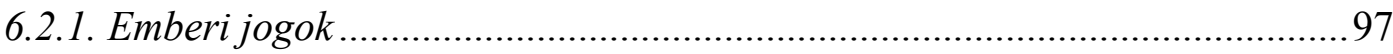

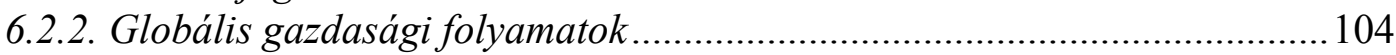

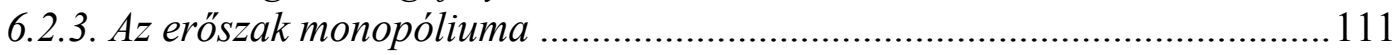

VII. FEJEZET: A NEM ÁLLAMI SZEREPLÖK SZÁMÁNAK ÉS

SZAKIRODALOMBAN VALÓ MEGJELENÉSÉNEK VÁLTOZÁSA 118

VIII. FEJEZET: KONKLÚZIÓ 125

IRODALOMJEGYZÉK 133

A TÉMAKÖRREL KAPCSOLATOS PUBLIKÁCIÓK 145 


\section{ÁBRÁK JEGYZÉKE}

1. ábra: A hatalom típusai Nye szerint .................................... 52

2. ábra: A társadalmi hálózatok globális térképe 2011-ben........................65

3. ábra: A Facebook felhasználók számának növekedése.........................66

4. ábra: A transznacionális nem állami szereplők hatása a döntéshozatalra az állami struktúrák függvényében........................................ 73

5. ábra: Az Európai Unió humanitárius segélyeinek elosztása.......................85

6. ábra: Nemzetközi nem kormányzati szervezetek száma..........................120

7. ábra: Nem állami szereplők említésének száma a szakirodalomban I..............121

8. ábra: Nem állami szereplök említésének száma a szakirodalomban II............ 123 
„A nemzetközi politika egy küzdősport, és még az oly erös államoknak is engedniük kell az elveikböl biztonságuk és jólétük érdekében."

(Walt 2011, p. 6) 


\section{FEJEZET \\ BEVEZETÉS}

Az elmúlt évtizedekben a nemzetközi érdekérvényesítési arénában dominánssá váló résztvevőként tüntek fel a nem állami szereplök. Ahogyan a 17. és a 18. század során a hatalomért folytatott küzdelemben a ma klasszikus szereplönek tartott nemzetállamok megjelenése és megerősödése jelentették a meghatározó változást, és ahogyan a 19. és a 20. században kétség kívül a nemzetközi szervezetek térnyerése okozott hangsúlyeltolódást a nemzetközi kapcsolatok alakításában, úgy a 21. század várhatóan a nem állami szereplők transznacionális szerepvállalásának évszázada lesz.

Már a második világháborút követően a transznacionális kapcsolatokra és az azokban részt vevő nem állami szereplőkre irányult a figyelem. Először az államok feletti szint, a nemzetközi szervezetek kaptak nagy hangsúlyt. A közvélemény a nemzetközi konfliktusok megoldását, a globális kihívásokra adandó válaszok megfogalmazását és megvalósítását várta a különböző nemzetközi szervezetektől. Növekvő szerepük tanulmányozása már az 1970-es években elérte csúcspontját, de a kutatások eredménye nem tükrözhetett mást, mint a nemzetközi rendszer realitását. A nemzetközi szervezetek térnyerése a felfokozott várakozások ellenére nem változtatta meg alapjaiban a nemzetközi rendszert. Az államok központi szerepét nem vették át a nemzetközi szervezetek, és nem valósult meg a globalizált világtársadalom sem.

Az állami szint alatti nem állami szereplők vizsgálata az 1960-as években kezdődött, ám sokkal kisebb figyelmet kapott egészen a múlt század végéig. (Risse-Kappen 1995) A kapitalista világgazdaság kiteljesedése a második világháborút követő európai és japán gazdasági újjáépítés során, ami a kereskedelmi liberalizáció és a befektetések mind globálisabb áramlásával, valamint a kommunikációs technológia fejlődésével járt együtt, az állami szint alatti „új” szereplők nemzetközi szerepének erősödésével párosult. (Josselin - Wallace 2001) Valójában - amint azt később látni fogjuk - nem a szereplök újak a rendszerben, hanem tevékenységük nemzetköziesedése, illetve nemzetközi hálózatosodása. Önkéntelenül is felvetődik tehát a kérdés, hogy a huszadik század második felében a globalizáció során összekapcsolódott földrajzi térségek után a nemzetközi gazdasági és politikai rendszerek jelenleg zajló globalizációja magával hozza-e ezen nem állami szereplők befolyásának további növekedését. Ennek 
valószínűségét növeli, hogy a 21. században mind több szó esik a transznacionális hálózatok megerősödéséröl, sőt a hálózatok hálózatosodásáról. A nem állami szereplök vizsgálatában az államok alatti szint, valamint a transznacionális nem állami szereplők kerülnek előtérbe. A jelen kutatás célja, hogy megvizsgálja, hogyan változott meg a nemzetközi kapcsolatok szereplőinek súlya a 20. század során, és milyen hangsúlyok várhatóak a következő évszázadban. Jelent-e új kihívást a nem állami szereplők befolyásának növekedése, és ha igen, mely területeken és milyen formában?

A kutatás során óvatosságra int, hogy „A hidegháború végével véget ért a „,rövid 20. század” is. Elkezdődött a 21. század, amelynek még most is csak az elején vagyunk, amelynek folyamatairól, történetének tendenciáiról még csak hipotéziseket formálhatunk." (Horváth 2007, p. 18)

A fentiek alapján a következő hipotéziseket fogalmazom meg:

A)

A 21. században a nem állami szereplök számának és befolyásának növekedésével a nemzetközi rendszer állami dominanciája megszünni látszik, az államok közötti kapcsolatok helyett a transznacionális kapcsolatok válnak meghatározóvá. B)

A politikai tér átrendeződése és a hatalom jellemzőinek átalakulása, egy „új középkor" kialakulását eredményezi, ahol a hatalom több kézben oszlik meg.

C)

A nem állami szereplök számának és képességeinek növekedése miatt hatalmi transzfer megy végbe az államoktól a nem állami szereplök felé, amik ezáltal az államok konkurenseivé válnak.

A hipotézis bizonyításához a kutatás az alábbiakra koncentrál:

1. A nemzetközi politikai és gazdasági rendszer 21. századi sajátosságainak elemzése. A globalizáció hatásai, a globális kihívások és az azokra adandó válaszok nehézségei az államok részéről, valamint az azok nyújtotta lehetőségek a nem állami szereplők számára.

2. A nemzetközi kapcsolatok új értelmezése. A külpolitika belpolitizálódása és a belpolitika külpolitikai vonatkozásainak felerősödése. A transznacionális kapcsolatok jelentőségének növekedése, a nemzetközi kapcsolatok és a transznacionális kapcsolatok fogalmi megkülönböztetése. 
3. Az állami funkciók bővülése, a be nem töltött állami funkciók által létrehozott vákuum, valamint a vákuum betöltésére képes és kész nem állami szereplök megjelenése nemzeti szinten és a transznacionális kapcsolatokban. Az állami és nem állami szereplők interakciója a transznacionális kapcsolatokban.

4. A nem állami szereplők megjelenésének területei, okai, feltételei. A jövőben várható tendenciák és azok várható hatásai.

A kutatás során megvizsgálom, hogy a nem állami szereplök befolyásának növekedése valóban igazolható-e, és ha igen, akkor ennek milyen rendszer szintű okai határozhatók meg. Ez a növekvő befolyás mely területeken jelentkezik, és azok közül melyek azok, ahol közép-, illetve hosszútávon fenn is tud maradni. Ehhez mindenekelőtt azt kell megvizsgálni, hogy a nemzetközi kapcsolatok értelmezése hogyan bővül, milyen területek nemzetköziesednek.

A nem állami szereplök megjelenése és megerősödése alapvetően két területen figyelhető meg. Egyrészt olyan vákuumokat töltenek be, amelyeket az állam nem tud, vagy nem kíván betölteni - legyen az gazdasági, szociális vagy éppen biztonsági természetü. Másrészt azokon a területeken jelennek meg ezek a szereplők, amelyek az államok szintje felett, a határokon átnyúló lehetőségek vagy szükségletek folytán válnak elérhetővé. Klasszikus példája ennek a globalizációból eredő transznacionális gazdasági lehetőségek vagy épp a globális környezetvédelmi kihívások.

Számuk növekedése és befolyásuk erősödése különböző feltételek teljesülésére vezethető vissza, úgy mint a kommunikáció fejlődése, vagy a gazdasági háttér erősödése. Fontos tisztázni, hogy ezek a feltételek teljes mértékben adottak-e már, vagy várható még olyan változás, ami tovább erösítheti fellépésüket és befolyásolási képességüket.

Az elemzés rámutat arra is, hogy az egyes területeken milyen mértékben érvényesül ezen aktorok befolyása. Választ igyekszik adni arra, hogy megállapítható-e valamiféle törvényszerüség, hogy az egyes kérdéskörökben milyen típusú nem állami szereplök játszanak meghatározó szerepet. Nem törekszik ugyanakkor arra, hogy a szereplők átfogó definícióját megalkossa. Sokkal inkább célja, hogy a szereplöket ismérveik alapján kategorizálja, esetleg meghatározza a transznacionális kapcsolatokban való bekapcsolódásuk szempontjából legfontosabb tulajdonságaikat.

Megvizsgálom, hogy a nem állami szereplők a nemzetközi kapcsolatok mely résztvevőivel lépnek interakcióba. Más-más típusú kapcsolatot figyelhetünk meg a nem állami szereplők nemzetközi szervezetek irányába kifejtett tevékenysége, az államokkal 
kialakított interakciók és az egymás közötti érintkezés esetén. Egészen speciális eset, ám mindenképp vizsgálatra érdemes az Európai Unióval kialakított kapcsolat, az unió befolyásolásának módja és eredménye.

A kutatás fontos része az interakciók jellegének feltérképezése is. Jelentős különbségek vannak az egyes kölcsönhatások tartalma, hatásmechanizmusa és eredménye között. A nem állami szereplők tevékenységének egyszerü leírásán túl a vizsgálat egyik kulcskérdése e tevékenységek eredményessége. A többi transznacionális vagy nemzetközi szereplő magatartása megváltoztatásának lehetőségén túl végső soron a befolyásolás hatékonysága adja meg az igazi választ a feltett kérdésekre.

A kutatás során azonosított területeken és a szignifikáns interakció-típusokra vonatkozóan konkrét példák segítségével kívánom bemutatni a nem állami szereplők részvételét a nemzetközi kapcsolatok alakításában. Ezek a példák egyszersmind a befolyás határait is kirajzolják. Kérdés azonban, hogy a jelenlegi határok véglegesnek tekintendők-e, avagy a jövőben e határok kitolódásának leszünk-e tanúi. Ezen aktorok részvételének a nemzetközi kapcsolatokban vannak természetes határai, jogi korlátai és politikai fékjei.

A disszertáció végén röviden felvázolom azt a problematikát is, ami a növekvő számú nem állami szereplő legitimitásának és reprezentativitásának kérdéséből adódik. Az alapvetően írott- és szokásjogi alapokon müködő - amennyiben az erőszak alkalmazását tekintjük a szabálytól eltérő magatartásformának - nemzetközi rendszerben ezen szereplők helye, jogai, kötelezettségei és lehetőségei közel sem tisztázottak. Ebből adódóan legitimitásuk és képviseleti joguk korlátainak vizsgálata sem megkerülhető az elemzés során.

Ezeknek a kérdéseknek a tisztázása sok felvetésre megadja a választ, ugyanakkor várhatóan számos más kérdést indukál. Hasonlóan lényeges és ugyancsak bonyolult kérdés ezen szereplők elszámoltathatóságának kérdése, ami nem értelmezhető csak a jelenlegi helyzetre vonatkoztatva, hanem a nemzetközi rendszer egészének fejlődésével párhuzamosan vizsgálandó.

A nemzetközi gazdasági viszonyok alakulása jelentős mértékben befolyásolja a nemzetközi rendszer alakulását, a szereplők egymás közötti viszonyait. A különböző szereplök gazdasági erejének változása érdekérvényesítési képességük változását is jelenti egyben. A múlt század második fele azt mutatta, hogy az államokhoz képest a nem állami szereplők relatív gazdasági ereje növekedett. Ez a folyamat azonban erős korrelációt mutat a globális gazdasági növekedéssel, és az abban bekövetkező változás 
visszahat a vizsgált szereplőkre. A 21. század elején fellépett gazdasági válság ilyen értelemben mérföldkő lehet. Kérdés, hogy a gazdasági válság mennyi ideig tart és mekkora hatással lesz a nem állami szereplőkre? Vajon a nem állami szereplők - sajátos müködési módjuk előnyeit kihasználva - képesek lesznek-e fenntartani tevékenységüket, vagy esetleg az állami szereplők befelé fordulását ellensúlyozva egyes területeken megerősíthetik szerepvállalásukat?

A fenti kérdések mind-mind más aspektusát világítják meg a nem állami szereplök érdekérvényesítési képességének. Az ezekre kapott válaszok alapján lesz lehetséges a hipotézis igazolása vagy elvetése, és annak a kérdésnek a megválaszolása, hogy a nem állami szereplők milyen jellegü és milyen mértékü kihívást fognak jelenteni a nemzetközi rendszer többi szereplője számára a jövőben. Várhatóan választ kapunk arra a kérdésre is, hogy képesek lesznek-e a nem állami szereplök a nemzetközi kapcsolatokban domináns szerepet betölteni vagy továbbra is egy államközpontú rendszer részei lesznek, ahol az államok határozzák meg a kereteket, és diktálják a feltételeket. A válasz függvényében az állami szereplők, az állami diplomácia más-más kihívással fognak szembesülni a 21. században.

A hipotézis bizonyításához az alábbi struktúrát követem:

A második fejezetben mindenekelőtt meghatározom az általam használt fogalmakat, majd a nemzetközi kapcsolatok jelenlegi kereteit ismertetem. Ezt követően áttekintem a szakirodalom vonatkozó iskoláit, és meghatározom az elemzéshez legmegfelelőbb irányt.

A harmadik fejezetben áttekintem a nemzetközi kapcsolatok változó értelmezését, és abban a nem állami szereplők változó mozgásterét. Egyrészt foglalkozom a nemzetközi kapcsolatok határainak módosulásával, illetve a nemzetközi rendszer fö mozgatórugójának tekintett „,hatalom” fogalmának és összetevőinek időbeli változását.

A negyedik fejezetben elemzem a nem állami szereplők befolyása változásának rendszer szintű okait, és befolyásolási képességük változását. A nemzetközi rendszer hálózatosodása, és a mind nagyobb számban megjelenő globális kihívások olyan új feltételeket teremtenek, amelyekhez a különböző nemzetközi szereplőknek alkalmazkodniuk kell, ha meg kívánják őrizni, avagy növelni próbálják súlyukat a nemzetközi rendszerben.

A ötödik fejezetben azt vizsgálom, hogy milyen szinteken és a nemzetközi kapcsolatok milyen szereplőivel kerülnek interakcióba a nem állami szereplők, és azt is, hogy ebben a tekintetben megfigyelhető-e időbeli változás. 
A hatodik fejezetben a nem állami szereplők adottságainak változását veszem górcső alá. Megvizsgálom, hogy milyen tulajdonságaik járulnak hozzá ahhoz, hogy a korábbinál nagyobb szerepet játszhassanak a transzatlanti kapcsolatokban.

A hetedik fejezetben foglalkozom számuk és interakcióik változásának kvantitatív elemzésével, ami alátámaszthatja vagy cáfolhatja elméleti megállapításaimat. Ez a fejezet statisztikai elemzés eredményei alapján készül.

Mindezek alapján tartom megválaszolhatónak a fentebb feltett kérdéseket, és a disszertáció hipotézisének elfogadását, avagy elvetését. 


\section{FEJEZET \\ ELMÉLETI KERET}

A disszertáció során az alább meghatározott fogalmakat használom. Ezek ismertetését a definíciós nehézségek miatt, amivel a kutatás során szembesültem, tartom kiemelten fontosnak. A kutatás elméleti alapjainak megválasztásához áttekintettem a nemzetközi kapcsolatok vonatkozó elméleteit, és kiválasztottam azokat, amelyek a nem állami szereplők vizsgálatához a legmegfelelőbb kiindulási pontot biztosították.

\subsection{A használt elméleti fogalmak}

\subsubsection{Nem állami szereplök}

A nem állami szereplők tárgyalásakor nagyon hamar szembesülünk a definíciós problémával. A definíció e szereplök nagyfokú különbözősége és folyamatos változása miatt nehezen határozható meg. A globalizáció hatására megváltozó nemzetközi kapcsolatokban egyre szélesebb az új szereplők köre, egyre nagyobb a nem állami szereplők száma és egyre sokszínübb a jellege. Nem törekszem arra, hogy a szereplők átfogó definícióját megalkossam. Sokkal inkább cél, hogy a szereplőket ismérveik alapján kategorizáljam, esetleg meghatározzam a nemzetközi kapcsolatokba való bekapcsolódásuk szempontjából a legfontosabb tulajdonságaikat. Az általános definíció megalkotása helyett elméleti megalapozásként meghatározom, hogy a nem állami szereplők mely csoportjára terjed ki az elemzés. Az alapsokaság meghatározását követően egy-egy alcsoport esetében már létező definíciót veszek majd alapul.

A nem állami szereplők széles köre miatt az egyes kutatások során használt definíciók gyakran különböznek, így azok eredményeiből csak az általános érvényü következtetések használhatók fenntartások nélkül. Gyakran a vizsgált szereplök köre sem tekinthető egységesnek. A legtöbb szerző nem törekszik egyetlen, átfogó definíció megalkotására.

A vizsgálat szempontjából érdekes kiindulási pont lehet a megnevezésből adódó negatív definíció. Az államtól mint a nemzetközi rendszer legfőbb aktorától való megkülönböztetés azt a történelmi fejlődést mutatja, amely során a vesztfáliai 
rendszerhez képest újnak tekintett szereplők jelentek meg. Míg a vesztfáliai rendszerben a nemzetállamok voltak a meghatározó nemzetközi szereplök, és az államok mint homogén egységek közötti interakciók határozták meg a nemzetközi rendszer alakulását, addig jelenleg a nem állami szereplők jelenlétének és jelentőségük növekedésének lehetünk tanúi. Megerősödésük következtében bizonyos területeken az államokéhoz hasonló befolyással bírnak, ami indokolja azt, hogy vizsgálat tárgyává tegyük öket. Philip Alston ${ }^{1}$ ugyanakkor helyesen mutat rá arra, hogy már magának a „nem állami szereplő” elnevezésnek a használatával is a „nem macska” szindrómában szenvedünk, vagyis az államot, mint fö viszonyítási pontot helyezzük a középpontba, és ezzel implicit módon marginalizáljuk kutatásunk tárgyát. (Alston 2005) Josselin és Wallace $^{2}$ még határozottabban érvel a negatív definícióval szemben. Véleményük szerint az államtól való megkülönböztetés, az állami felügyelettől való függetlenség kizárólagossága azért nem megfelelő definíció, mert egyenesen félrevezeti az olvasót. Egy ilyen definíció két okból sem lenne elfogadható. Egyrészt mert nem tesz különbéget az államok feletti szint (nemzetközi szervezetek, integrációs formák, szövetségek) és az államok alatti - esetenként melletti - szint között. Másrészt, mert az utóbbi, állami szint alatti kategóriába is a transznacionális vállalatoktól (TNC) kezdve a nemzetközi nem-kormányzati szervezeteken (INGO), transznacionális szociális mozgalmakon és érdekvédelmi csoportokon át a terrorista szervezetekig sok minden tartozik. Közülük egyre több rendelkezik nemzetközi viszonylatban is jelentős, az államoktól független, önálló befolyásolási képességgel, ugyanakkor szerepük, müködésük jelentősen különbözhet. (Josselin - Wallace 2001) Továbbá nem tekinthető adottnak az sem, hogy minden szerző a nem állami szereplők azonos körét érti bele az általa használt definícióba.

Sok szerző szerint inkább a csoport tagjainak, alcsoportjainak meghatározásán keresztül van lehetőség egyfajta definícióra, mint sem a közös jellemzők meghatározása révén. Kiindulási alap lehet Peter Willetts $^{3}$ meghatározása (Willetts 1982), ami a nem

\footnotetext{
${ }^{1}$ Philip Alston nemzetközi jogász, a New York University School of Law professzora. Az ENSZ különleges jelentéstevője, aki azt megelőzően több magas ENSZ beosztást töltött be. Tudományos munkásságában a nem állami szereplők emberi jogi tevékenységét vizsgálja.

${ }^{2}$ Daphne Josselin a London School of Economics and Political Science nemzetközi kapcsolatok oktatója. Kutatási területe a nem állami szereplök nemzetközi politikában játszott szerepe. William John Lawrence Wallace, Baron Wallace of Saltaire a London School of Economics and Political Science emeritus professzora, író és politikus. 2010-től a konzervatív-liberális demokrata koalíció Government Whip-je.

${ }^{3}$ Peter Willetts a londoni City University professzora. Szakterülete a világpolitikai folyamatok vizsgálata, valamint a nem kormányzati szereplők befolyása a gazdaságpolitika alakítására az IMF és a WTO szintjén.
} 
kormányzati szervezeteket $\left(\mathrm{NGO}^{4}\right)$, üzleti csoportokat, politikai szervezeteket, vallási közösségeket és bünszervezeteket foglalja magában. Jóval tágabb kört fed le Le Gloannec ${ }^{5}$ definíciója, amely szerint nem állami szereplők az érdekvédelmi szervezetek, multinacionális vállalatok (MNC), legális és illegális termelők és kereskedők, kereskedelmi vállalatok, migránsok, diaszpórák, egyházak, militánsok, maffia csoportok és zsoldosok. (Le Gloannec 2007) A szakirodalom áttekintése során kiderült, hogy a nem állami szereplök köre még a fenti definíciónál is tágabb, mivel ide tartoznak a transznacionális vállalatok (TNC), a pénzügyi alapok, a békemozgalmak, a magán biztonsági cégek, a terrorista szervezetek, a szeparatista mozgalmak, és ide sorolhatjuk a különböző nem állami finanszírozású tudományos kutatóintézeteket (think tank), a médiát, valamint transznacionális érdekképviseleti hálózatokat is. Ez a felsorolás jól mutatja a nem állami szereplők sokféleségét, és egyben arra is rávilágít, hogy szinte lehetetlen teljes, átfogó képet adni róluk.

További probléma, hogy még az egyes "alcsoportok" definiálása is sok nehézségbe ütközik. Ezek a nehézségek lehetnek jogi természetűek, politikai okokra visszavezethetőek, vagy akár tudományos definíciós problémák. Az NGO definícióját Bokorné többé-kevésbe egyértelmüen megadja. „Az államok tagságával működő nemzetközi szervezetektől meg kell különböztetni az ún. nem-kormányzati szervezeteket (non-governmental organisations: NGO). Számtalan olyan nemzetközi szervezet létezik ugyanis, amelyek müködése több államra terjed ki, de tagjai nem maguk az államok, hanem az egyes államokban tevékenykedő társadalmi, tudományos, kulturális és emberbaráti egyesületek, társaságok illetve természetes személyek is. E szervezetek nem nemzetközi szerződés útján, hanem a székhelyük szerinti államnak az egyesületek működésére vonatkozó belső jogszabályai alapján jönnek létre, illetve fejtik ki tevékenységüket.” (Bokorné 2000, 19.o.) Ugyanakkor az Európai Bizottság az NGOk meghatározását problematikusnak tartja, és öt ismérv alapján próbálja azonosítani azokat, amelyet maga sem tart tökéletes megoldásnak. A TNC-k esetében Szentes a definíció kapcsán rávilágít arra, hogy milyen sokféle meghatározás létezik (Szentes 2005), az MNC-re vonatkozó ENSZ definíció pedig jó példája annak, hogy mennyire

\footnotetext{
${ }^{4}$ Jelen elemzésnek nem célja az NGO különböző értelmezéseinek bemutatása. Az NGO-t, mint a nem állami szereplők egyik alcsoportját kezeli - ide értve elsődlegesen a téma természetéből adódóan a transznacionális kapcsolatokban részt vevő, nemzetközi NGO-kat, de figyelmen kívül hagyva az ,álNGO”-król (GINGO, BINGO, RINGO, stb) folyó vitát. (Halliday 2001)

${ }^{5}$ Anne-Marie Le Gloannec az Institut d'Etudes Politique de Paris kutatási igazgatója, a L'Express és a Le Figaro publicistája. Európa-politikával foglalkozik, kiemelt figyelemmel az állam szerepének alakulására. További kiemelt kutatási területe a német föderális állam, illetve az a feletti és alatti szintek kapcsolódása.
} 
nehéz választó vonalat húzni az ,állami” és a „nem állami” közé. „A multinacionális vállalatok egyik definíciója az ENSZ szakértői csoportja szerint: „olyan vállalkozások, amelyek székhelyállamukon kívül fekvő termelő vagy szolgáltatási eszközök tulajdonosai vagy ezek felett ellenőrzést gyakorolnak. Nem szükségképpen részvénytársaságok vagy magántársaságok, hanem lehetnek az államhoz kapcsolódó szövetkezetek vagy egyéb egységek is.” (Dinh et al. 1997, p. 341) Fontos ugyanakkor hangsúlyozni, hogy egyik definíció sem foglalja magában az államok által létrehozott nemzetközi szervezeteket. Azokat a jelen kutatás is megkülönbözteti a nem állami szereplőktől. Ennek egyik oka, hogy bár bizonyos paraméterek alapján a nemzetközi szervezeteket is besorolhatnánk a nem állami kategóriába, azok - egyre önállóbb saját létük ellenére - az államok tevékeny részvételével müködnek. Másik oka, hogy a nemzetközi szervezetek tevékenységét, és azok hatását a nemzetközi kapcsolatokra a szakirodalom részletesen megvizsgálta a 20. század második felében, és a szerzők többsége arra a következtetésre jutott, hogy a nemzetközi szervezetek olyam államok feletti szintet képviselnek, ami nem változtatja meg alapvetően az államközpontú nemzetközi rendszert.

A jelen kutatás során az általános keretek bemutatásakor igyekszem minél szélesebb körre figyelni, majd szükítve a kört a részletes vizsgálat során a nem állami szereplőknek csak egy szükebb csoportjára fókuszálni. A nem állami szereplők körébe sorolom a nem kormányzati szervezeteket, az érdekvédelmi szervezeteket, az érdekképviseleti hálózatokat, a multinacionális vállalatokat, transznacionális kereskedelmi vállalatokat, a pénzügyi alapokat, a békemozgalmakat, a szeparatista mozgalmakat, a terrorista szervezeteket, a magán biztonsági cégeket, a kutatóintézeteket és a média bizonyos szereplőit. Azt feltételezem, hogy nem annyira a pontos definíció megalkotása, mint inkább annak megállapítása a kulcskérdés, hogy a nem állami szereplők jelentős számbeli növekedése együtt jár-e befolyásuk, érdekérvényesítő képességük növekedésével? Ezt az egyes kölcsönhatások vizsgálata során, illetve esettanulmány formájában olyan nem állami szereplőkre szúkítve elemzem, mint NGO$\mathrm{k}$, transznacionális pénzügyi szervezetek, magán biztonsági és katonai cégek, stb. A kvantitatív elemzés során a nem állami szereplöket, NGO-kat, INGO-kat, transznacionális vállalatokat és transznacionális érdekképviseleti hálózatokat vizsgálom. Ha kimutatható a növekedés, akkor ennek milyen külső (rendszer szintü) vagy belső (aktor-specifikus) okai vannak? Befolyásuk növekedése mennyiben jelent hangsúlyváltozást a nemzetközi rendszer struktúrájában és szereplőinek vizsgálatában? 


\subsubsection{Transznacionális kapcsolatok vs. nemzetközi kapcsolatok}

A transznacionális kapcsolatok megkülönböztetése a nemzetközi kapcsolatoktól alapvető fontosságú a jelen értekezés szempontjából. Mindkettő feltételezi, hogy a „kapcsolat” nemzeti határokon átnyúlva jön létre, ugyanakkor lényeges különbség, hogy míg a nemzetközi kapcsolatok az államok mint egységek interakcióját feltételezik, addig a transznacionális kapcsolatok részben vagy egészben az államok alatti szinten jönnek létre.

A transznacionális kapcsolatok meghatározása két szempontból is lehetséges. Robert O. Keohane $^{6}$ és Joseph Nye Jr. ${ }^{7}$ a kapcsolatot kialakító „nemzetközi” szereplők köre alapján határozza meg a fogalmat: transznacionális az a határokon átnyúló kapcsolat, amelyben legalább az egyik résztvevő nem állam. (Keohane - Nye 1972) Huntington ${ }^{8}$ ugyanakkor a transzatlanti tevékenységet az interakció által érintett terület alapján közelíti meg, és azt a meghatározást adja, hogy a transznacionális kapcsolat egy vagy több államhatáron átnyúló tevékenység során alakul ki, függetlenül attól, hogy az állam szintjén, avagy az alatt történik-e. (Huntington 1973) A két megközelítés közös jellemzője, hogy az államok közötti kapcsolatokat jelentő hagyományos nemzetközi kapcsolatok helyett (Morgenthau 2005, Mersheimer 2001, és mások) az állami szint alatt létrejövő kapcsolatokat helyezik a vizsgálat középpontjába.

\subsubsection{Befolyás/hatalom}

A befolyás, avagy hatalom a nemzetközi kapcsolatok és erőviszonyok alakításának módja és képessége. A nemzetközi interakciókban részt vevő másik szereplők magatartása alakításának képessége. A nemzetközi interakciókban való szabályozott vagy spontán részvétel.

\footnotetext{
${ }^{6}$ Robert Keohane a Princeton University Woodrow Wilson School politikatudomány professzora. Korábban a Harvard, Duke, Swarthmore, Stanford és Brandeis oktatója. A Nemzetközi Tanulmányok Társaság és az Amerikai Politikatudományi Társaság korábbi elnöke. A neoliberális institucionalizmus kiemelkedő alakja. 1984-ben írt „After Hegemony” címü könyve az irányzat meghatározó irodalma, amelyért Grawemeyer-díjat kapott.

7 Joseph Nye Jr. a Harvard University professzora, korábban az egyetem John F. Kennedy School of Government dékánja. Fő kutatási területe a hatalmi és függőségi viszonyok neoliberális vizsgálata. Az ezredfordulón a hatodik legbefolyásosabb nemzetközi kapcsolatok szakértőnek tartották, és az amerikai külpolitika legbefolyásosabb alakítója.

${ }^{8}$ Samuel Phillips Huntington amerikai politológus, az Amerikai Tudományos Akadémia tagja, a 20. század második felének kiemelkedő elemzője. Kutatásainak központi kérdése a világrend átalakulása, amely a hidegháború végét követően megjelent „Clash of Civilizations” címü könyvével kapott kiemelt figyelmet.
} 
A nemzetközi kapcsolatok alakítása szempontjából az egyik legfontosabb kérdés, hogy a különböző szereplők milyen formában képesek befolyásolni egymás viselkedését annak érdekében, hogy elérjék céljaikat. Vannak-e ezen interakcióknak intézményesült csatornái, vagy éppen a vizsgálat időszakában tanúi lehetünk-e ilyen intézményesülési folyamatnak? Amennyiben nem, akkor az ad hoc alapon történő kapcsolatfelvételekben tudunk-e törvényszerüséget, ismétlődést kimutatni?

A fenti kérdések megválaszolásához először is meg kell határozni az interakciók területét. Megvizsgálom, hogy a nem állami szereplök a nemzetközi kapcsolatok mely egyéb szereplőivel lépnek interakcióba. Más-más típusú kapcsolatot figyelhetünk meg a nem állami szereplők nemzetközi szervezetek irányába kifejtett tevékenysége, az államokkal kialakított interakciók és az egymás közötti érintkezés esetén.

Fontos vizsgálati szempont, hogy a befolyást milyen csatornán keresztül tudják érvényesíteni a nem állami szereplők, és a gyakorolt befolyás mértékének meghatározása ugyancsak lényeges a végkövetkeztetések levonásához. Eltérö lehet ezen szereplök befolyásának mértéke közvetett és közvetlen ráhatás esetében, ezért ennek a két útnak a külön-külön történő elemzése hasznos hozzáadott értékkel bír a vizsgálat tárgyának alapos megértéséhez.

\subsection{A nemzetközi kapcsolatok jelenlegi keretei}

A 21. században a nemzetközi kapcsolatok vizsgálata során kiemelt figyelmet kap a nemzetközi szereplök számának és jellegének változása. Ennek legfőbb oka, hogy a hatalom forrásának változásával egyre fontosabb szerepet kapnak, kaphatnak ezek a szereplök.

A nemzetközi interakciók továbbra is a fennmaradásért, a hatalomért és a befolyásolás képességéért folytatott küzdelemről szólnak. A hatalom meghatározása, a veszélyek és leküzdendő kihívások azonban egyre összetettebbé, egyre változatosabbá válnak. A történelem során a különböző periódusokban más-más szereplők dominanciája határozta meg a nemzetközi rendszer alakulását.

Abban az időszakban, amikor birodalmak dominálták a világ egyes térségeit, hatalmukat a terület, a lakosság és a természeti kincsek birtoklása határozta meg, amelyek megtartását vagy növelését pedig elsődlegesen katonai erővel, esetleg szövetséggel vagy házassággal biztosították. A hatalom tulajdonképpen egyenlő volt a katonai hatalommal. Ehhez katonaság kellett és a katonaság fenntartásához szükséges 
jövedelmek, mindenekelőtt adóbevételek. Az adóbevételeket elsősorban a terület nagysága és a lakosság száma határozta meg.

Később a birodalmak helyét a nemzetállamok vették át, és azok váltak - mind a mai napig - központi szereplőkké. Érdekérvényesítési képességüket, egymáshoz való viszonyaikat a gazdasági és a katonai erő együttese határozza meg - mind nagyobb hangsúllyal a gazdasági hatalmon. Megfigyelhető továbbá, hogy az elmúlt három évszázad domináns aktoraiként jellemzett nemzetállamok mellett mind nagyobb számban jelennek meg olyan nem állami szereplők, amelyek markáns hatással vannak a nemzetközi kapcsolatok különböző szintjeinek és a transznacionális kapcsolatoknak az alakulására.

Az 1648-as vesztfáliai béke óta létező állam központú nemzetközi rendszerben magukon az államokon túl először a nemzetközi szervezetek kaptak nagyobb figyelmet. Azok a 19. század során kezdtek megalakulni, többnyire a létrejövő nemzetállamok köré fonódva. (Blahó - Prandler 2005) Fontos megemlíteni, hogy a nemzetközi szervezetek az államok együttműködési szándékának eredményeként, az államok tevőleges magatartásával, tehát az államok által meghatározott módon és feltételekkel jönnek létre. A nemzetközi szervezetek bár bizonyos szuverenitással rendelkeznek, azt csak az államok jóvoltából gyakorolhatják, és döntéseik a részes államok döntéseinek eredői. A szuverenitás átruházásának mértéke szervezetenként, illetve egy-egy szervezet fejlődésével változhat, de az államok ma még tartózkodnak attól, hogy szuverenitásuk lényeges részét átruházzák a nemzetközi szervezetekre. Amennyiben mégis megteszik, azt minden esetben jól felfogott érdekeik alapján, saját elhatározásukból teszik.

Megnövekedett szerepük, eszmei és politikai vonzerejük ellenére azonban a nemzetközi szervezetek nem tudták átvenni a nemzetállamok szerepét. Egyrészt, mert működésük során a nemzetállamoktól függenek, befolyásuk alapvetően a nemzetállamok által rájuk ruházott hatáskörre épül. Másrészt nincsen meg a szükséges társadalmi támogatottságuk, nehezen követhető és lassú a döntéshozatali folyamatuk, így nem is képesek gyorsan reagálni a felmerülő társadalmi vagy gazdasági problémákra. Döntéseik hatása szinte sohasem jelentkezik közvetlenül, így még eredményes müködésük babérjait is a helyi szinten jobban érzékelhető jelenléttel rendelkező államok, esetleg állam alatti szinten működő szereplők aratják le.

A 21. században az állam alatti szinten jelen lévő - nem állami - szereplők száma és aktivitása folyamatosan nő. Természetesen ezen szereplők jelenléte a nemzetközi kapcsolatok bizonyos területein nem új keletü. A kalózok hatása a nemzetközi 
kereskedelemre illetve a nemzetközi biztonságra, vagy a Brit Kelet-Indiai Társaság tevékenysége - és még sorolhatnánk - mind ebbe a történelmi kategóriába tartozik. Bizonyos értelemben a nem állami szereplők korábban léteztek, mint maguk az államok, hiszen az államok kialakulása hosszú történelmi folyamat eredménye. A mai államközpontú, úgynevezett vesztfáliai rendszert ugyan 1648-tól számítjuk, ám ezt megelőzően is beszélhetünk - más jellegű és szűkebb körü - nem államok közötti kapcsolatokról. Ugyanakkor figyelemre méltó jelenség, hogy a nem állami szereplők száma és befolyása az elmúlt évtizedekben, tehát történelmi léptékkel mérve rövid idő alatt ugrásszerüen megnőtt. Pontos számuk, már csak definíciós nehézségek miatt is, meghatározhatatlan, de bizonyosan több tízezerre tehető. Mathews ${ }^{9} 35.000$ nem kormányzati szervezetről (NGO) beszél, amelyek mind nagyobb része jelenik meg aktív szereplöként a nemzetközi kapcsolatokban. (Mathews 1997) Huntington szerint a nemzetközi nem kormányzati szervezetek (INGO) száma a második világháborút követő évtizedekben megduplázódott. (Huntington 1973) Az INGO-k számának növekedéséröl de Wilde ${ }^{10}$ ad számszerü adatokat, aki azt állapította meg, hogy 1909-től 1988-ig 176-ról 4.518-ra emelkedett a számuk. (de Wilde 1991) Emellett nem feledkezhetünk meg a globalizáció kínálta lehetőségeket kihasználó gazdasági szereplőkről, amelyek száma folyamatosan emelkedik: legyen szó a multinacionális és transznacionális vállalatokról, vagy a pénzügyi alapokról. Ahhoz, hogy teljes képet kaphassunk, figyelembe kell vennünk a hagyományosan pozitív szereplőnek tartott egyházak és a békemozgalmak többé-kevésbé konstansnak tekinthető számát, vagy az épp ellenkezőleg negatív szerepet betöltő és jelentős mértékben növekvő szervezett bűnözői csoportok és nemzetközi terrorista szervezetek számát is. Természetesen nem hagyhatjuk figyelmen kívül a kommunikációs forradalom vívmányainak köszönhetően dinamikusan szaporodó médiát vagy a korábban a definíció meghatározása során említett többi nem állami szereplőt sem.

A nem állami szereplők tehát a nemzetközi kapcsolatoknak nem új szereplői. A modern-kori történelemből kiindulva a nemzetközi kapcsolatokat az államok közötti kapcsolatok területének tekintjük, és transznacionálisként utalunk azokra a kapcsolatokra, amelyekben államhatárokon átnyúlva nem állami szereplők vesznek

\footnotetext{
${ }^{9}$ Jessica Tuchman Mathews a Carnegie Endowment for International Peace elnöke. Korábban a Council on Foreign Relations programigazgatója, valamint a Nemzetbiztonsági Tanács igazgatója volt. Továbbá több nem kormányzati szervezet elnökségi tagja.

${ }^{10}$ Jaap de Wilde a University of Groningen nemzetközi kapcsolatok professzora. Korábban a Vrije Universiteit Amsterdam és a University of Twente tanára, valamint a Copenhagen Peace Research Institute kutatója. Kutatásai az állami szuverenitás, illetve annak változására koncentrálnak.
} 
részt. Érdekes kérdés lenne annak a vizsgálata, hogy hogyan értelmezhetnénk a nemzetállamok kialakulása előtti „nemzetközi” kapcsolatokat, amelyeknek definíció szerint csak nem állami szereplők lehettek a részesei. Ez azonban egy másik disszertáció témája lehet.

\subsubsection{A nem állami szereplök térnyerése}

A vesztfáliai békét követően kialakult nemzetközi rendszer egyértelműen államközpontú volt, a nemzetállamok szuverenitásán alapult, azok egymás közötti interakciójára épült, és azokat a nemzetközi kapcsolatok alakításának kizárólagos szereplőiként kezelte. Három évszázadon keresztül, bár léteztek az államokon kívül más nemzetközi aktorok, azok hatása elenyésző maradt az államközi kapcsolatok uralta világszínpadon. Általánosságban megállapíthatjuk, hogy a fokozatos hangsúlyeltolódás az állami és nem állami szereplök között a második világháború után kezdődött. Az azóta eltelt évtizedek során jól megfigyelhető volt, hogy a nem állami szereplök száma és aktivitása fokozatosan nőtt. Megjelentek nemcsak a nemzetállami határokon belül, hanem egyre nagyobb mértékben a transznacionális kapcsolatokban is - mind több területen. Bár láttuk, hogy a legtöbb szerző igyekszik elkerülni a negatív definíció használatát, mégis legtöbb esetben az állam attribútumaihoz vagy aktivitásához viszonyítva határozzuk meg a nem állami szereplők tevékenységét. Jelen elemzés egyik fontos szempontja is az államokkal, illetve államok csoportjaival való interakciók formája és hatékonysága: nevezetesen, hogy kiegészítik az államok, illetve a nemzetközi szervezetek tevékenységét, alakítani vagy korlátozni kívánják azt, avagy át kívánják venni a hagyományosan állami kiváltságoknak tekintett funkciókat.

A nemzetközi rendszer 20. századi újraformálása során egyre nagyobb jelentőségre tettek szert olyan nem állami szereplők, amelyek egy-egy területre fókuszálva tevékenységükkel fontos hozzájárulást tesznek bizonyos problémák megoldásához. Az első jelentősebb mérföldkőnek számított az új szereplők térnyerésében az 1950-es évek óta az emberi jogok érvényesítéséért folytatott küzdelem, vagy az 1960-as években elötérbe került környezetvédelmi problémák megoldására tett erőfeszítések. Ahogyan Horváth fogalmaz „Földünk globális problémái - amelyekre például a Római Klub jelentései már az 1970-es években felhívták a figyelmet - egyre aggasztóbbá, fenyegetőbbé váltak: mindenekelőtt a természeti környezet pusztulása, az erdők kiirtása, a vizek szennyezése, az üvegházhatást eredményező légkörszennyezés és a 
népességrobbanás következtében." (Horváth 2007, p. 14) Ezeknek a folyamatoknak a vizsgálata az 1970-es években egészen odáig fejlődött, hogy megkérdőjeleződött az államközpontú világrend elsődlegessége, és helyette a nem állami szereplők vagy más megközelítésben a transznacionális társadalmi szereplők által dominált transznacionális kapcsolatok kialakulásának lehetősége került az elemzések központjába. A legtöbb vonatkozó elemzés azonban a nemzetközi szervezetekre koncentrált, és nem lépett ki a neorealista-liberális intézményi vita ${ }^{11}$ keretei közül, vagyis fenntartotta azt az alapvető kiindulási tételt, hogy a nemzetközi kapcsolatok legfőbb alakítói a nemzetállamok, valamint a nemzetközi és a nemzeti kormányzati szintek között is az államok teremtik meg a kapcsolódást. (Czempiel 1969, Kaiser 1969, Keohane - Nye 1972, Rosenau 1980) Ennek megfelelően végkövetkeztetésük is belül maradt az állam-központú megközelítésen. A nem állami szereplők befolyásolási képességét nem tartották kellően erősnek ahhoz, hogy átvegyék az államok szerepét, mint a nemzetközi rendszer meghatározó szereplője. Ahogy azonban Risse-Kappen ${ }^{12}$ fogalmaz, a 70-es években folyó, az államközpontú és társadalom-központú megközelítések közötti ellentétet a középpontba állító vitát idő előtt lezárták. Az eredeti kérdésfeltevés ugyanis nem hozott eredményt, ugyanakkor maga a kérdés nem is volt helyes. Szerinte nem az a kérdés, hogy felváltja-e a nem állami szereplők által dominált világrend az államközpontút, hanem az, hogy hogyan és milyen mértékben hat a két párhuzamosan létező rendszer egymásra. (Risse-Kappen 1995)

A helyi problémákat szőnyeg alá söprő, a globális problémákkal pedig nem foglalkozó kétpólusú világ megszünése, a hidegháború vége lökést adott a civil szféra szerepvállalásának és befolyása növekedésének. A két egymással szemben álló blokk közötti katonai és biztonságpolitikai szembenállás megszünése a katonai hatalmat szinte kizárólagosan birtokló államok központi szerepét elhalványította. A globalizáció felerősödése ezzel párhuzamosan előtérbe helyezte a civil és gazdasági szereplőket. A nemzeti és nemzetközi folyamatok közötti határok mind jobban megfigyelhető összemosódása pedig ismét felerősítette a globális társadalom és a nem állami szereplők befolyása körüli vitát. Rosenau ${ }^{13}$ rámutat a nemzetközi kapcsolatok változó jellegére,

\footnotetext{
${ }^{11}$ Lásd részletesen később.

12 Thomas Risse-Kappen a Freie Universitat Berlin professzora. A nemzetközi kapcsolatok konstruktivista elméletének képviselője, aki elsősorban német szociológiai és filozófiai alapokra épít. A hidegháború végét követően kezdett el a transznacionális kapcsolatok kérdésével foglalkozni.

${ }^{13}$ James N. Rosenau a George Washington University Elliott School of International Affairs professzora. A világpolitika dinamikájával, az egymást átfedő bel és külpolitikai cselekvési szintekkel foglalkozik.
} 
Loaeza ${ }^{14}$ pedig egyenesen a civil társadalom győzelme szimbólumának nevezi a berlini fal ledöntését. (Rosenau 1990, Le Gloannec 2007)

A 90-es években tehát a nem állami szereplök nemzetközi rendszerben elfoglalt helye vizsgálata újabb hullámának lehetünk tanúi. A kérdés akkor azonban már nem úgy merül fel, hogy befolyásolják-e a nem állami szereplök a nemzetközi kapcsolatokat, hanem úgy, hogy hogyan teszik azt. (Risse-Kappen 1995, Cerny 1995, Held 1995) Egyes szerzők a térségünkben lezajlott rendszerváltás lefolyásának a módját is a nem állami szereplők határokon átívelő kapcsolatrendszerének, és a meglévő együttmüködéseknek tudják be. A kapitalizmusba és demokráciába való átmenet menedzselésének előfeltétele volt a társadalmi szereplők nemzetközi beágyazottsága, az emberi jogi és békemozgalmak nem állami szereplőinek aktivitása. Természetesen a nem állami szereplők tevékenysége önmagában nem lett volna elég ilyen mértékü politikai változások kikényszerítésére, de feltétlenül szükséges volt ahhoz. Ezt tükrözheti a poszt-szocialista országok elért eredményeinek különbözősége, azaz a nyugati térséggel szorosabb kapcsolatot ápolt államok sikeresebb átmenete. (Chilton 1995) A kétpólusú világ megszünése nem hozott létre merőben új nemzetközi rendszert. A globalizáció felerősödése az, ami olyan rendszerjellemzők fontosságát növelte meg, amelyek a nem állami szereplők befolyását fokozzák.

Hasonlóan fontos mérföldkőnek szokták tekinteni a globális klímaváltozásról 1992-ben Rio de Janeiróban rendezett „Föld-csúcsot” abban az értelemben, hogy a nem állami szereplők első ízben vehettek tevőlegesen részt államközi tárgyalásokban. Vanuatu állam a Greenpeace nevü szervezetre bízta érdekeinek - és ezen keresztül több más csendes-óceáni szigetországénak - a képviseletét. Ennek egyik oka az volt, hogy a kezelendő probléma - a globális felmelegedés hatására bekövetkező környezeti károk államhatárokon átnyúló, az egyes államok által nem kezelhető jelenség volt, másik oka pedig, hogy a Greenpeace környezetvédelmi kérdésekben olyan mennyiségű szakmai tudást halmozott fel, és olyan mértékü elismertséget élvezett, aminek segítségével hatékonyabban tudta képviselni Vanuatu érdekeit, mint a szigetország saját képviselői. A globális problémák előtérbe kerülése, illetve a globalizáció általában nem jelenti feltétlenül az államok jelentőségének változását. „A globalizáció aligha befolyásolja az

Kiemelt figyelmet fordít a nemzetközi rendszer szereplőinek vizsgálatára - az egyéntől a közösségeken át az államig.

${ }^{14}$ Soledad Loaeza a Collegio de Mexico Centro de Estudios Internacionales professzor-kutatója, korábban igazgatója. Korábban a Mexikói Tudományos Akadémia Igazgatótanácsának titkára volt. Kutatási területe a politikai rendszerek müködése. 
állami lét koncepcionális megközelítését; nem ösztönzi az államisággal szembeni alternatíva létrejöttét." (Armstrong 1997, p. 477) Ugyanakkor Risse-Kappen azzal a megállapítással él, hogy „,nincs logikai kapcsolat az állítás, miszerint a nemzetállamok a nemzetközi politika meghatározó szereplői maradnak, és a következtetés, miszerint a társadalmi szereplők és a transznacionális kapcsolatok irrelevánsak lennének, között.” (Risse-Kappen 1995, p. 15) Sőt egyes vélemények szerint „a politikai szembenállás megszűnése, és a globalizáció hatására kialakuló új működési keretek is nagymértékben elősegítik a nem állami szereplők aktivitásának megnövekedését a politika, a gazdaság és a szociális kérdések területén, amelyek természetszerüleg egymással is összefüggenek". ${ }^{15}$ (Welling 2007, p. 147)

A globalizáció, mint a nem állami szereplők megerősödésének egyik kétségtelen oka ugyanakkor a 2008-ban kirobbant pénzügyi és gazdasági válság kiteljesedésével akár visszájára is fordíthatja ezt a folyamatot. Kérdés, hogy a nem állami szereplők aktivitásának tendenciája megfordul-e, vagy a már elért szintet fenn tudják tartani. A gazdasági válság minden bizonnyal hatással lesz azokra a forrásokra, amelyek ezen szereplők tevékenységét lehetővé teszik - legyen szó akár a civil szféra, akár a gazdasági társaságoktól származó támogatásokról, de még a nemzetközi szervezetek költségvetési soraiban is elképzelhető módosulás, mégpedig negatív irányba. A globalizációnak a technológiai lehetőségekre gyakorolt hatása ugyanakkor nem fog visszájára fordulni. A kommunikációs technológia színvonala várhatóan tovább emelkedik, és költségeinek csökkenési tendenciája sem valószínü, hogy megváltozna. Mindazonáltal a politikai, intézményi hajlandóság a globalizáció, a gazdasági liberalizáció és a nemzetköziesedés irányába számottevően csökkenni fog. Szinte bizonyos, hogy az olyan nagy világgazdasági szereplők mint az Egyesült Államok, az Európai Unió vagy Kína hajlani fognak a protekcionizmus felé bizonyos területeken, és ezáltal kevésbé hitelesen tudják képviselni az áruk, tőke, személyek és szolgáltatások szabad világméretű áramlásának eszméjét. Igaz ez akkor is, ha figyelembe vesszük, hogy az USA, Kína és az EU globalizációhoz való hozzáállása alapvetően különböző. Az amerikai és a kínai megközelítés alapvetően az ad hoc módon, egyedi mérlegelés alapján megkötött kétoldalú megállapodásokat részesíti előnyben. Kevésbé van jelen a globális szabályozásra való törekvés, a nemzetközi szervezetek kereteiben elfogadott,

15 A globalizáció tágabb összefüggéseiben, az állami hegemóniára gyakorolt hatás szempontjából vizsgálja a nem állami szereplők befolyását a századfordulón több szerző: Strange (1996), Schechter (1999), Cox (1999). A nem állami szereplők befolyása vizsgálatának történelmi vonatkozásait pedig a 20. század második felében lásd részletesebben: Daphné - William (2001). 
minden csatlakozó államra érvényes előírások iránti igény és betartására vonatkozó hajlandóság. Ez utóbbi megközelítés sokkal inkább az európai szereplők sajátja. Az európai országok szívesebben gondolkoznak intézményesített keretekben, mint az EU, az OECD vagy éppen a WTO. Kérdés, hogy egy recessziós periódusban illetve az azt követő kilábalás időszakában e két megközelítés mennyiben fogja gyengíteni egymást, és mennyire fogja ellehetetleníteni a globális szabályozás előmozdítását. Márpedig gazdasági és politikai elkötelezettség nélkül mind a gazdasági szereplők, mind az intézmények, de még a civil szféra is bizonyosan kisebb támogatást nyújt majd a globális kérdésekkel vagy más országok belső problémáival foglalkozó transznacionális nem állami szereplőknek.

A nemzetközi jogi szabályozás szempontjából ugyanakkor - ahogyan Bokorné fogalmaz (Bokorné 1999) - továbbra is az állam marad a nemzetközi kapcsolatok legfőbb szereplője. Csak az államok rendelkeznek szuverenitással. Az államok nemzetközi megállapodással nemzetközi szervezeteket hozhatnak létre. Ezek jogalanyisága visszavezethető a szuverenitásra és mindenekelőtt az államok akaratára. A nemzetközi szervezetek jogalanyisága származtatott jellegű és terjedelme változó, de szükségképpen szúkebb, mint az államoké, mivel az államok ragaszkodnak hatásköreik minél nagyobb mértékü megtartásához. (Nemzetközi okmányokban a nemzetközi jog alanyának szokták tekinteni a népeket illetve nemzeteket is, valamint speciális esetekben a felkelőket, az ellenállási- illetve felszabadító mozgalmak képviselőit.)

A nemzetközi szervezetek (IGO) szerepének elemzésétől eltekintünk, egyrészt mivel azok az állami akarat megnyilvánulása egyik formájának tekinthetők, egyetértve Bokornével és Fitzmaurice, ${ }^{16}$ a Nemzetközi Jogi Bizottság raportőre definíciójával, ami szerint a nemzetközi szervezetek államok társulásai nemzetközi szerződés révén, amelyek alkotmánnyal, közös szervekkel és saját, a tagállamokétól eltérő jogalanyisággal bírnak. (Dinh 1997) Másrészt, mert a nemzetközi kapcsolatok alakítása szempontjából a nemzetközi szervezetek döntései többségükben nem kötelezőek. A saját működésükre vonatkozó belső szabályozáson túl mindössze két példát említhetünk a kötelező erejü döntésekre: az ENSZ Biztonsági Tanácsának határozatait valamint a Nemzetközi Polgári Légiközlekedési Szervezet (ICAO) szabályait. (A kötelező erejü döntések kikényszeríthetőségének - és ezen keresztül hatékonyságának -

\footnotetext{
${ }^{16}$ Sir Gerald Fitzmaurice elismert nemzetközi jogász. Karrierje során többek között a hágai Nemzetközi Büntető Bíróság és a strasbourgi Európai Emberi Jogi Bíróság bírája, az ENSZ Nemzetközi Jogi Bizottsága raportöre, valamint a Grotius Társaság elnöke volt.
} 
problematikája külön elemzést érdemelne.) Mint arra korábban is utaltunk, nem tartozik a klasszikus nemzetközi szervezetek közé az Európai Unió, amint azt a nem állami szereplők EU-n belüli érdekérvényesítésével foglalkozó fejezetben látni fogjuk. Míg az államok szintjén több-kevesebb hagyománya van az interakcióknak, és a nemzetközi szervezetek közül is mind több alakít ki együttmüködést a nem állami szereplökkel, az EU intézményeinek a különböző érdekképviseleti vagy lobby szervezetekkel való kapcsolattartása formáinak kialakítása folyamatosan zajlik.

Nemzetközi jogi szempontból a 20. század legújabb jelensége a nemzetközi kapcsolatok alanyi körének az egyénnel való kibővülése tekinthető. Az emberi jogok védelmével összefüggésben olyan nemzetközi megállapodások jöttek létre, amelyek lehetővé teszik, hogy egyének jogaik megsértése esetében nemzetközi fórumokhoz fordulhassanak. A nemzetközi büncselekményi kategóriák megalkotásával (például kalózkodás, háborús bünök) valamint a Nemzetközi Büntető Bíróságok felállításával az egyén nemzetközi felelősségre vonhatósága is megvalósult. Nagyon fontosnak tartom itt tisztázni, hogy a nemzetközi közjog normarendje egyetlen transznacionális nem állami szereplöt (INGO, TNC, MNC, stb) sem ismer el a nemzetközi jog alanyaként. Jogi értelemben ezek a szereplők nem nemzetközi aktorok, rájuk a nemzeti jog vonatkozik, bár tevékenységük során nemzetközi szinten lépnek fel, illetve önszabályozásuk során nemzetközi normákat alkothatnak, érvényesíthetnek. Transznacionális tevékenységük erősödésével párhuzamosan az a kérdés is mind relevánsabbá válik, hogy milyen mértékben van szükség a nem állami szereplők tevékenységének nemzetközi szabályozására, illetve ez mennyiben lehetséges.

\subsection{A nemzetközi kapcsolatok vonatkozó elméletei}

A 20. század második felében - és várhatóan a 21. században is - a nemzetállam központú nemzetközi rendszer paradigmája olyan új kihívásokkal nézett szembe, amelyek ugyan nem képesek még egy teljesen új paradigma megalkotásának feltételeit biztosítani, de mindenképp a nemzetközi viszonyok új szemléletét követelik meg. „Ezekben az években olyan tudományos kihívások érték a diszciplínát, melyek a tudományág „szent barmának”, a nemzetállamnak a szuverén főszereplői mivoltát feszegetik, [...] két oldalról is:

- a nem-állami szereplők jelentőségének növekedése, 
- valamint a wallersteini ,világrendszer” által kínált szemléleti alternatíva következtében.” (Galló 1994, p. 110)

A nemzetközi rendszer evolúciója az azóta eltelt időben exponenciális módon erősíteni látszik a fenti tendenciákat. Bár még egyik esetben sem beszélhetünk kiforrott, új elméletről, a következőkben arra törekszem, hogy a nem-állami szereplők jelentőségének változását, annak okait és potenciálját, valamint esetleges korlátait tüzetesebben megvizsgáljam.

A nem állami szereplők helyének és tevékenységének vizsgálata nem kapott számottevő figyelmet a klasszikusnak tekintett elméleti iskolák részéről. A realista felfogás egyértelmüen államközpontú, a neorealista iskola a nemzetközi kapcsolatokat rendszerszinten vizsgálja, a liberális szemlélet az egyén oldaláról közelíti meg a kérdést, a neoliberálisok (institucionalisták) a nemzetközi szervezeteket helyezik a vizsgálat középpontjába. A globalista iskolák a hálózatos nemzetközi rendszertől a világtársadalom víziójáig terjedő spektrumban gondolkodnak.

\subsubsection{Realista iskola}

A realista iskola mind a tudományos életben, mind a nemzetközi kapcsolatok gyakorlatában megkerülhetetlen szerepet tölt be. „A wilsoni hagyományok és a külpolitka-elemzés intézmény- és policy-központú hagyományai mellett jórészt az európai tudástranszfer eredményeként a második világháborút követően [a realizmus] vált a kutatási napirendek meghatározó referenciájává, [...] s ez a szintézis [...] a nemzetközi kapcsolatok diszciplinájának megszilárdulásához és az identitását meghatározó realizmus triumfálásához vezetett." (Kiss J. 2009, p. 79) Ugyan sokan kritizálták, illetve kritizálják amiatt, hogy a változó nemzetközi környezet bizonyos jelenségeire nem ad magyarázatot, de bizton állíthatjuk, hogy a 20. században az elméletek többsége a realista nézetek mellett, vagy ellenében határozta meg önmagát.

A realista felfogás szerint - amelynek alaptételeit Morgenthau ${ }^{17}$ a Chicagói Egyetemen 1948-ban kiadott Politics among Nations címü tankönyvében összefoglalta - a nemzetközi rendszer a hatalom megszerzésére, megtartására vagy növelésére irányuló anarchikus természetű rendszer. „A világ legpontosabban az államok nemzetközi rendszereként (statism) írható le. Ez a jelentőség az államokat a történelmileg kialakult

\footnotetext{
${ }^{17}$ Hans J. Morgenthau a nemzetközi kapcsolatok elméletének egyik kiemelkedő 20. századi alakja. A University of Chicago, a New School for Social Studies és a City University of New York oktatója.
} 
legitimitásuk, de még inkább annak a puszta ténynek a következtében illeti meg, hogy az erőszak-alkalmazás katonai eszközeivel rendelkeznek, és azok alkalmazásáról maguk döntenek.” (Kiss J. 2009, p. 222)

A másik központi kérdés a realista felfogásban az államok túlélésért folytatott küzdelme, illetve a túlélés, mint katonai-biztonsági kategória biztosításának elsődlegessége. Ez a felfogás alapvetően a véges számú, és a 20. és 21. században már csak egymás rovására terjeszkedni képes államok biztonsági dilemmájából, annak is elsődlegesen a katonai vonatkozásaiból indul ki. Morgenthau-t jelentősen inspirálta Niebuhr, ${ }^{18}$ az amerikai protestáns ortodoxia újjáélesztője, aki a konfliktusos nemzetközi rendszert arra vezette vissza, hogy nem lehet olyan nemzetközi közösséget kialakítani, amely képes és hajlandó lenne egy nemzetközi társadalmi szerződést létrehozni, és ami még fontosabb, azt be is tartani illetve tartatni. Nem létezik ugyanis a nemzetközi leviatán. Ezen a ponton Niebuhr még korábbra utal vissza: Hobbes ${ }^{19}$ természeti törvényére, és a társadalmi rend fenntartásához - véleménye szerint - szükséges szuverén hatalomra, a leviatánra. Lényeges eltérés azonban, hogy míg Hobbes éles különbséget tesz az emberek közösségi szintje, a társadalom valamint az államok közösségi szintje, a nemzetközi rendszer között, addig Niebuhr a kettőt analóg módon kezeli.

Morgenthau, a „human nature” realizmus fö képviselője a hatalom-orientált nemzetközi politikát az emberi természet dominancia-vágyából vezeti le. A dominanciára és a biztonságra való párhuzamos törekvés eredményezi a konfliktusokat, amelyek az ö felfogásában az államok szintjén jelennek meg. Hat elv mentén bontja ki nézeteit:

1. A politika (a nemzetközi politika is) objektív törvényeken alapul, amelyek az emberi természetet tükrözik. E törvények állandóságának feltételezése teszi lehetővé számára, hogy racionális elméletet állítson fel a politikai folyamatok magyarázatára.

2. A realista iskola egyik sarokköve a hatalom megszerzésére vagy megtartására irányuló érdekek primátusa. Ezek az érdekek a racionalitás talaján állva kiszámíthatóak, és elméleti síkon vizsgálva objektívek. A realisták - ahogyan

\footnotetext{
${ }^{18}$ Karl P. R. Niebuhr amerikai teológus és gondolkodó a 20. század első felében, aki nagy hatást gyakorolt a nemzetközi kapcsolatok realista elméletét követő kutatókra és gyakorló politikusokra, így például Morgenthaura, de többek között Carterre, Albrightra és Obamára is.

${ }_{19}$ Thomas Hobbes of Malmesbury 17. századi angol politikai filozófus. Legtöbbet hivatkozott müve a Leviathan, az állam és a legitim kormányzás alapjairól. Felfogása a társadalmi szerződés szélsőségesen autoriter megközelítésére épül.
} 
arra Gelb ${ }^{20}$ az Amerikai Egyesült Államok példáján rámutat - azt tartják a legfontosabbnak, hogy az adott ország saját érdekeit kezelje legföbb prioritásként, és ne vegye magára a világ problémáit. Mindazonáltal a gyakorlatban néha a hatalomért folyó küzdelem önmagáért valóvá válik. Ez adódhat az elméleti megközelítés és a gyakorlati megvalósítás nem megfelelő összekapcsolásából éppúgy, mint az érintett ország belpolitikai viszonyaiból, vagy rajta kívül álló, általa nem befolyásolható nemzetközi eseményekből. (Gelb 2009)

3. Az érdekek - bár általánosan érvényesek és minden esetben a hatalomra irányulnak - nem állandóak és változatlanok, hanem az adott helyzethez igazodva folyamatosan alakulnak, a hatalom jellegének időbeli és térbeli változásával, fejlődésével együtt változhatnak.

4. A realisták ugyanakkor tisztában vannak azzal, hogy a politikai döntéseiknek vannak morális következményei, de tisztában vannak azzal is, hogy a politikai etika a döntéseket azok következményei alapján ítéli meg. Ez egybevág azzal, ahogy Lincoln a 19. században fogalmazott: „Legjobb tudásom és képességem szerint cselekszem, és mindig így fogok cselekedni. Ha az eredmény engem igazol, az ellenem felhozott vádak jelentéktelenné válnak. Ha az eredmény rám cáfol, még az sem változtat rajta, ha tíz angyal esküszik, hogy nekem volt igazam." (Morgenthau 2009)

5. A realista felfogás szerint egyetlen nemzet eszméi sem azonosíthatóak az univerzális eszmékkel. A hatalomközpontú érdekérvényesítés a legföbb vezérelv, ami egyben gátat is vet a morális túlkapásoknak. Határozottan megkülönbözteti a kívánatost a lehetségestől, az ideálist a reálistól, vagyis a nemzetközi kapcsolatok szereplöi cselekedeteinek eszméit és azok gyakorlati megvalósulását.

6. A politikai realizmus éles határt húz a politika, a gazdaság, a jog és az etika területei közé. Tekintettel van arra, hogy az érdekek meghatározásakor a nemzetközi aktorok nem vehetik csak és kizárólagosan a politikai tényezőket figyelembe, hiszen akkor politikai ragadozóvá válnának, de ugyanúgy, ahogy a jogász a jog szemüvegén keresztül, a közgazdász a gazdaság törvényszerüségei

\footnotetext{
${ }^{20}$ Leslie Howard Gelb az amerikai Council on Foreign Relations örökös elnöke. Korábban az amerikai Védelmi Minisztérium és a Külügyminisztérium munkatársa volt. Dolgozott a New York Times-nál, ahol újságírói tevékenységéért Pulitzer-díjat kapott 1986-ban.
} 
alapján, a politikus a politikai hatalomért folyó küzdelem primátusát szem előtt tartva definiálja érdekeit, és hozza meg döntéseit.

Gilpin $^{21}$ - a realizmus talaján állva, és az államközpontú megközelítést követve - fontos elmozdulást tett a nemzetközi kapcsolatok szereplői körének vizsgálatában. Bár a nemzetközi kapcsolatok fő jellemzői között kiemelten kezelte a konfliktusos, anarchikus nemzetközi rendszer létét, és kiállt a hatalom és a biztonság, mint legfőbb célok érvényesítésének szükségessége mellett, a nemzetközi rendszer szereplőinek körét tágabban értelmezi: „bár az állam a nemzetközi kapcsolatok elsődleges aktora, a realizmusnak a nemzetközi kapcsolatok meghatározásában az olyan nem állami szereplök fontosságát is el kellene ismernie, mint a multinacionális vállalatok, a nemzetközi intézmények és a nem kormányzati szervezetek (NGO-k)”. (Gilpin 2004, pp. 13-14)

Gilpin az 1980-as években a nemzetközi gazdasági kapcsolatokban lejátszódott nagy horderejü változások alapján alakította ki megközelítését. A multinacionális vállalatok (MNC) egyre erősödő nemzetközi jelenlétét helyezte elmélete középpontjába. Megközelítésében az MNC-k külföldi közvetlen beruházásai kapcsán válik a globalizáció fogalma mind fontosabbá. Elmélete, a politikai gazdaságtan a piac és a hatalommal bíró szereplők kölcsönhatásának leírása. A nemzetközi gazdaság müködésének megértéséhez elengedhetetlen annak elfogadása, hogy a piacot az államokon kívül más gazdasági, politikai, illetve társadalmi szereplők is képesek érdemben manipulálni. Ugyanakkor nem lép ki az államközpontú realista felfogás kereteiből. Ragaszkodik ahhoz, hogy az államok hozzák azokat a szabályokat, amelyeket az egyéni vállalkozóknak és a multinacionális vállalatoknak követniük kell, elfogadva, hogy a gazdasági és technológiai erők is alakítják, befolyásolják az egyes államok politikáit és érdekeit, valamint a közöttük lévő politikai kapcsolatokat. (Gilpin 2004)

Gilpin értelmezése a nemzetközi politikai gazdaságtanról szükítő ugyan abban az értelemben, hogy a piac nézőpontjából vizsgálja a nemzetközi gazdasági szereplők kölcsönhatásait, kiterjesztő ugyanakkor abban a tekintetben, hogy a gazdasági realitásokat elismerve az állam mellett a multinacionális vállalatokat és a nemzetközi szervezeteket (vagyis a nem állami szereplők egy speciális körét) a rendszer „,erőteljes

\footnotetext{
${ }^{21}$ Robert Gilpin a 20. századi nemzetközi politikai gazdaságtan kiemelkedő amerikai származású alakja. A Princeton University professzor emeritus-a, az amerikai Council on Foreign Relations, a Politikatudományi társaság és a Tudományos Akadémia tagja.
} 
szereplőinek" tekinti. Ugyancsak különbséget tesz az állami és az állam alatti szint között, amikor az állam érdekeinek meghatározását a kormányzó politikai elit és a nemzeti társadalmon belüli csoportok nyomására vezeti vissza. „Egy társadalom gazdaság- és külpolitikája tükrözi a nemzet érdekeit, melyeket az adott társadalom domináns elitje definiál.” (Gilpin 1981, pp. 18-19)

\subsubsection{Strukturális realizmus - neorealizmus}

A klasszikus realista felfogást kiegészítve további fontos előrelépést jelentett a strukturális realista vagy neorealista megközelítés megjelenése. Waltz ${ }^{22}$ illetve Mearsheimer ${ }^{23}$ megközelítése abban a tekintetben hozott újat, hogy már nem csak az államok, mint homogén egységek interakcióit vizsgálta, hanem a nemzetközi rendszer struktúráját és sajátosságait is, amelyek meghatározzák a szereplők kölcsönhatásait.

Mearsheimer offenzív realista megközelítése Morgenthau-val szemben az államok konfliktusos magatartását, túlélésért folytatott küzdelmét egyértelműen az anarchikus nemzetközi rendszer létéből vezeti le, és nem a „human nature” megközelítésből. Az államok a rendszer szintjén hegemóniára törekszenek, mivel a hegemón pozíció megszerzésében látják a biztonság garanciáját. A hatalom ugyanis nehezen mérhető és alapvetően relatív fogalom, vagyis egyetlen állam sem lehet bizonyos abban, hogy az a hatalom, amellyel rendelkezik, elégséges céljai eléréséhez, és még kevésbé képes azt megítélni, hogy ez a hatalom elegendő lesz-e a jövőben. A nemzetközi rendszer szintjén soha sincsen status quo, hiszen az államok folyamatosan nagyobb hatalom megszerzésére törekszenek. A hatalom fogalma Mearsheimer-nél már összetett, térben és időben értelmezett. Egyrészt nem csak katonai hatalomról beszélt, másrészt nem feltétlenül globális értelemben értelmezte azt. A globális hegemón helyett regionális hegemón, illetve hegemónok rendszer szintű együttélését feltételezte. Rámutatott arra, hogy az államok veszíthetnek jelentőségükből, és az államok alatti, illetve feletti szintek a korábbinál nagyobb szerepet kaphatnak. Nagyon tág értelemben tehát már

\footnotetext{
${ }^{22}$ Kenneth Waltz 20. századi neorealista, strukturális realista amerikai kutató. A University of California Berkeley professzor emeritus-a, az amerikai Politikatudományi Társaság és a Tudományos Akadémia tagja.

${ }^{23}$ John Mearsheimer a University of Chicago politikatudomány professzora, aki korábban többek között a Harvard University tanára, a Brookings Institution és a Council on Foreign Relations munkatársa volt. Legutóbbi könyve, a Why Leaders Lie az államok közötti kapcsolatokat a vezetők hazai és külföldi partnereknek mondott hazugságain keresztül vizsgálja.
} 
foglalkozott a nem állami szereplők megjelenésével, illetve előtérbe kerülésével, de azt nem tekintette meghatározónak.

Waltz, akinek nézeteit defenzív realizmusként is szokták említeni, elfogadta, hogy az anarchikus nemzetközi rendszerben a különböző csoportok léte versengéshez, konfliktushoz vezet, de túllépett az államok emberi tulajdonságokból levezetett viselkedésének magyarázatán. „Hasonlóképpen a nemzetközi politika „egységei”, az államok is saját önfenntartásuk biztosítására önérdekeiket követik, ám ezzel szándék nélkül is létrehozzák a nemzetközi rendszer struktúráját, amely azután visszahat külpolitikai mozgásszabadságukra és külpolitikai választásaikra.” (Kiss J. 2009, p. 228) Ez az elemzési keret nagyobb teret enged a nemzetközi kapcsolatok szereplöinek tágabb értelmezésének, és jobban rávilágít az anarchiának, mint a szereplők feletti autoritás hiányának koncepcionális megközelítési lehetőségére. Az Egyesült Államok és a Szovjetunió például egyéni érdekeik alapján jutottak arra a közös felismerésre, hogy a rendszer stabilitása érdekében meg kell találniuk egymás kölcsönös megsemmisítésének alternatíváját, ami a nemzetközi rendszer későbbi alakulása szempontjából meghatározó lépésnek bizonyult.

Waltz hangsúlyozta, hogy rendszerszemléletében a szereplők egymáshoz viszonyított pozícióját elemzi. A klasszikus realista felfogással szemben nem vizsgálta a nemzetközi szereplők jellemzőit, azok magatartását, ahogy a szereplők interakcióját és indítékait sem. Amit vizsgált, az a szereplőknek a rendszeren belül egymáshoz képest elfoglalt helyük. Ebből a szempontból fontos különbség a bel- és a külpolitikai aréna között, hogy míg az elsőben a szereplők hierarchikus alá-fölérendeltsége a meghatározó, addig a másodikban a nemzetközi politikai rendszer szereplői elméleti szinten egyenlők, egymás mellé rendeltek, és az anarchikus nemzetközi rendszer felsőbb hatalomtól mentes. A neorealista elmélet már foglalkozik az olyan nem állami szereplők helyével a nemzetközi rendszerben, mint a nemzetközi szervezetek, illetve államok feletti szervek, integrációs struktúrák, de azok tulajdonságait, cselekvési képességét még az államokra vezeti vissza. Waltz szerint a szupranacionális szereplők vagy állami jelleggel rendelkeznek, vagy cselekvési képességük megköveteli bizonyos meghatározó országok (államok) hozzájárulását. Vagyis végső soron a szupranacionális nem állami szereplök aktivitását, és legföképpen cselekvési, befolyásolási képességét az államok - még pontosabban az adott rendszer elsődleges és meghatározó politikai egységei: városállamok, birodalmak, államok, stb. - cselekvési képességére, illetve hajlandóságára vezette vissza. (Waltz 2009) 
A neorealista felfogás tehát megmarad az állam-központú nemzetközi rendszer logikájában. Elismeri a nem-állami szereplök létét, sőt bizonyos értelemben (pl.: MNC) növekvő befolyását, ugyanakkor hangsúlyozza, hogy egyrészről az államok soha sem kizárólagos szereplői voltak a nemzetközi rendszernek, másrészröl a nem állami szereplők jelenlétéből nem következik automatikusan az állami szereplők, mint meghatározó egységek háttérbe szorulása. Arra hívja fel a figyelmet, hogy az adott nemzetközi „rendszert nem az összes abban részt vevő szereplő által definiáljuk, hanem a meghatározó szereplők alapján.” (Waltz 1979, p. 86) Ezen felül fontos megállapítás és a nem-állami szereplök befolyása növekedésének vizsgálata szempontjából fontos pont - hogy a 20. század második felének vizsgálata során a gyakorlat még egyértelmüen azt mutatta, hogy az államok szabják meg a nem állami szereplők tevékenységének müködési kereteit vagy úgy, hogy nem avatkoznak bele a tevékenységükbe, vagy úgy, hogy vonatkozó szabályozást alkotnak, módosítanak, esetleg visszavonnak. Mindaddig, amíg a szabályozás képessége az államok szuverén kiváltsága marad, az államok tekinthetők a rendszer meghatározó szereplőinek. Kérdés azonban, hogy az államok a szabályozás képességével vagy csak annak illúziójával rendelkeznek-e.

Ugyancsak fontos lépés a neorealista felfogásban, hogy a realizmusban kizárólagosnak tekintett „túlélésért való küzdelem” célján kívül az adott állam helyzetétől, a nemzetközi rendszer állapotától függően több más célt is lehetségesnek, illetve fontosnak tart. Ez azzal magyarázható, hogy az államok túlélése, mint elsődleges cél olyan nemzetközi rendszerben értelmezhetö, ahol az államok léte veszélyben van. A második világháborút követően azonban ez a megközelítés érezhetően háttérbe szorult.

\subsubsection{Liberális iskola}

A történelmileg Kant (1724-1804) nevével fémjelzett liberális iskola elutasítja a nemzetközi kapcsolatoknak kizárólagosan a hatalom és a hatalmi egyensúly fogalmain keresztül történő vizsgálatát. Kilép az államközpontú megközelítés kereteiből, és az állam alatti szintet (egyén, gazdasági szereplők, stb.) állítja az elemzés fókuszába. Legfőbb jellemzője az egyéni szabadság elvének érvényesülése, az egyének kapcsolati hálójának fejlődése révén az együttmüködés kialakítása, és a békés nemzetközi viszonyok megteremtése. Legyen szó akár a konzervatív, akár a liberális irányzatról (más néven a laissez-faire, illetve a szociáldemokrata liberalizmusról), közös 
jellemzőjük az együttmüködés erejébe és a konfliktusok elkerülésének lehetőségébe vetett hit. Mindazonáltal nem állíthatjuk, hogy a béke iránti vágy liberális eszméje kizárná vagy ellehetetlenítené a szereplők közötti konfliktusokat - vagy akár a háborúkat. Hitet tesz azonban amellett, hogy a konfliktusokra és a túlélésért való küzdelemre épülő államközi kapcsolatok helyett az egyének közötti kapcsolatokra, valamint az egyénekre vonatkoztatott szabadságokra (politikai, gazdasági, szociális, oktatási, stb.) helyezve a hangsúlyt csökkenteni lehet a konfliktusokat. A kereskedelem, az oktatás, a nemzetközi társadalmi kapcsolatok mind ezt erősítik. Bizonyos értelemben nem is a nemzetközi rend leírására törekszik, hanem annak bemutatására, hogy milyennek kellene lennie a nemzetközi rendszernek.

„Immanuel Kant és David Hume (1711-1776) nyomán a nemzetközi kapcsolatok liberális felfogásában három ideológiai örökség nyomai lelhetők fel. Az első, a statisztikailag és esettanulmányokkal operáló liberális vagy demokratikus béke koncepciója, vagyis a „béke elkülönült övezetének” kialakulása. A második, a liberális államoknak a nem liberális államokkal szemben tanúsított meggondolatlan agresszivitása. Végül a harmadik, a liberálisok túlzott engedékenysége a veszélyekkel és az izolacionizmussal szemben.” (Kiss J. 2009, p. 291) A liberalizmus legfőbb vívmányának általánosságban ugyanakkor azt tartják, hogy „,a háború hiánya a leginkább liberális felfogást követő országok között, akár szomszédosak, akár nem, az elmúlt kétszáz évben jól kimutatható.” (Doyle 1983, p. 212)

Moravcsik $^{24}$ felfogása a liberalizmus elméleti keretein belül annyiban tekinthető újnak, hogy véleménye szerint a nemzeti érdekeket a belpolitika alakítja, amely a különböző szubnemzeti (bizonyos értelemben nem állami) szereplők - intézmények, politikai-, érdekvédelmi- és lobby-csoportok - interakciójának eredményeként születik meg. A racionálisan cselekvő államokról azt feltételezi, hogy egyéni érdekeik alapján mérlegelnek, de azt az együttmüködés szemszögéből, annak haszna és a költsége alapján teszik. A nemzetközi színtéren továbbra is az államok a meghatározó szereplők, akik a belpolitikai színpadon kialakult értékrendet és érdekrendszert vetítik ki a nemzetközi kapcsolataikra. A nemzetközi érdekérvényesítés tehát elsődlegesen továbbra is az államok közötti kapcsolatok során történik.

\footnotetext{
${ }^{24}$ Andrew Moravcsik a Princeton University professzora, a nemzetközi kapcsolatok elmélete liberális iskolájának képviselője. A Brookings Institution tudományos munkatársa, korábban újságíró, azt megelőzően pedig az USA Kereskedelmi Minisztérium, a dél-koreai miniszterelnök-helyettes és az EK Bizottság munkatársa.
} 


\subsubsection{Neoliberális megközelítés}

A 20. század második felének világméretű változásai, a transznacionalizáció, majd a globalizáció, illetve ezek ellenpontjaként a regionális integrációk a nemzetközi rendszer értelmezésének új, neoliberális irányzatait hívták életre.

A neoliberális institucionalizmus képviselői abból a feltételezésből indulnak ki, hogy a nemzetközi szervezetek kellően megerősödtek a 20. század folyamán, és bár nem veszik át a nemzetállamok szerepét, a globalizálódó nemzetközi kihívásokat azoknál hatékonyabban képesek kezelni. „Ha egy fennálló szabályrendszer elégtelennek bizonyul, akkor egyszerüen újakat alkotnak, vagy módosítják a meglévőket." (Gilpin 2004, p. 379)

A teória nagyban mellőzi a biztonsági témákat és inkább a gazdasági és környezeti témákra koncentrál, arra építve, hogy a nemzetközi politika két részre osztható: biztonságra és politikai gazdaságtanra, amelyeken belül az együttmüködés valószínűsége nagymértékben eltér. A megközelítés korlátai azonban részben épp ebből vezethetőek le. A nemzetközi rendszer globalizálódása következtében mind több olyan terület került a figyelem középpontjába, ahol a nemzetközi szervezetek nem voltak képesek - nagyon különböző okok miatt - betölteni a nekik szánt funkciókat. Másrészt a nemzetállamok akarata, illetve ellenállása ezeken a területeken továbbra is meghatározónak bizonyult.

A teória képviselői gyakran nevezik az intézményeket a nemzetközi stabilitás kulcsának. Ezt abból vezetik le, hogy az együttmüködés kimutathatóan hozzájárul a stabilitás megteremtéséhez, az intézmények pedig megát az együttmüködést testesítik meg, mivel azzal a céllal jönnek létre, hogy megteremtsék az együttmüködés kereteit. Az intézmények léte és az együttműködésen keresztül megvalósuló stabilitás tehát szorosan összefonódik. A neoliberális institucionalisták elfogadják a realisták alapfeltevéseit, például, hogy az államok egy anarchikus rendszerben léteznek, de vitatják az együttmüködések nehézkes voltát. Felfogásukban az államok puszta léte nem kell, hogy fenyegetést jelentsen. Kapcsolataik sokkal inkább a kölcsönösen elönyös együttmüködés (kereskedelem, vagy politikai szövetség) lehetőségét hordozzák magukban.

Az 1970-es évek olajválsága a nemzetközi gazdasági kapcsolatok új aspektusára irányította rá a figyelmet. A globális összefonódások miatt megjelenő gazdaságikereskedelmi nehézségek a kölcsönös függőség, illetve egymásrautaltság 
problematikáját helyezték a középpontba, és a konfliktusos nemzetközi rendszer elemei együttmüködésének szükségességére hívták fel a figyelmet. A kölcsönös függőség tételéből kiindulva az interdependentisták a konfliktusos nemzetközi viszonyok nemzetközi szervezeteken keresztül történő csökkenését vizionálják, és az együttmüködés fokozását látják a járható útnak.

Keohane - az 1919-ben létrehozott Népszövetség kudarcától a második világháborút követő intézményépítési hullámon keresztül, az 1970-es évek gazdasági kihívásaira válaszul létrehozott pénzügyi-gazdasági szervezeteken át az 1980-as évek globalizációs és interdependencia jelenségei hatására megnövekedö nemzetközi együttmüködésig - a 20. századot elemezve precíz képet fest a nemzetközi együttműködés, és az annak keretet adó nemzetközi intézmények müködésének, illetve hatékonyságának fejlődéséről. Véleménye szerint „1974-ben Henry Kissinger, aki nem fordított különösebb figyelmet a nemzetközi szervezetekre, annak érdekében segítette elö a Nemzetközi Energia Ügynökség létrehozását, hogy a nyugati országok sikeresen működhessenek együtt az 1973-ashoz hasonló Hollandiát és az Egyesült Államokat sújtó OPEC embargóval szemben.” (Keohane 1998, p. 83) Ehhez hasonlóan, később új pénzügyi rezsim és kereskedelmi szervezet is létrejött.

A nemzetközi együttmüködés intézményesedő formája természetesen felvetett olyan alapkérdéseket, mint az államok és a nemzetközi intézmények viszonya, a kölcsönös befolyásolási képesség, illetve az államok együttmüködési hajlandósága az intézmények keretei között - legyen szó klasszikus multilateralizmusról mint az ENSZ, vagy olyan speciális szupranacionális struktúráról mint az Európai Unió. A kritikák között megfogalmazódott, hogy a nemzetközi szervezetek csak úgy lehetnek hatékonyak, ha van egy domináns tagállam, aki biztosítja a döntések meghozatalát és végrehajtását is ez viszont az adott tagállam érdekérvényesítési eszközévé teszi a szervezetet. Bár az észrevétel bizonyos értelemben igaz, látni kell, hogy egy multilaterális szervezetben a döntések végeredménye szinte sohasem esik egybe egyetlen tagállama álláspontjával sem, még a legbefolyásosabb tagállam is kompromisszumokra kényszerül. A kompromisszum-kényszer szolgál a másik markáns kritika alapjául, amennyiben az államok nem hajlandóak együttmüködni a nemzetközi szervezetek keretein belül, mert félnek az elszenvedhető relatív veszteségektől, illetve a másik relatív nyereségétől. A relatív hatalmi pozíció kérdése valóban a nemzetközi kapcsolatok egyik sarkalatos pontja, ugyanakkor az intézmények müködése bizonyította, hogy az államok felismerték azt a tényt, hogy a bilaterális nyereség-veszteség kalkulációkhoz képest a 
multilaterális fórumokon sokkal kevésbé mutatható ki egyértelmü kapcsolat az egyes országok kompromisszumkötésböl adódó vesztesége és más országok nyeresége között, illetve a nyereségek és veszteségek több ország közötti megoszlásából adódóan valójában sokkal kisebb egy-egy döntés hatása a relatív hatalmi pozíciókra.

Keohane és vele egyetemben Nye a transznacionális kapcsolatok elméletén keresztül megkérdőjelezte a nemzetközi kapcsolatok szigorúan államközpontú realista paradigmáját. (Keohane - Nye 1972) Megközelítésük a 70-es évek végétöl folyamatosan a rendszert mozgató erőviszonyok, a hatalom egyenlötlen eloszlása szempontjainak vizsgálata felé tolódott el. A hatalom összetevőinek változásán, a hatalom gyakorlásának módján keresztül mutatták be azt, hogy hogyan mozdul el a nemzetközi rendszer a hagyományos nemzetközi kapcsolatoktól a nem állami szereplők tevékenységét jobban számba vevő transznacionális kapcsolatok felé. A nemzetközi szervezetek befolyásán túl egyre nagyobb figyelmet fordítottak más nem állami szereplők vizsgálatára.

A transznacionális kapcsolatok szereplöinek befolyásolásra való törekvését a „világpolitikai paradigma”, illetve a „globális kormányzás” kereteiben értelmezik. Ezeknek a kapcsolatoknak a száma és jelentősége az élet szinte minden területén megnövekedett: legyen szó nemzetközi gazdasági, pénzügyi, politikai, emberi jogi, környezetvédelmi, vagy egyéb kapcsolatokról. Ezeknek a területeknek a hatalmi politika klasszikusnak tekintett katonai vonatkozásait mind nagyobb mértékben túlhaladó jelentősége alapján Keohane és Nye azt a következtetést vonta le, hogy a nem állami szereplők növekvő befolyása a transznacionális kapcsolatok növekvő jelentőségü területein maguknak a nem állami szereplőknek a rendszerben elfoglalt pozíciójának erösödéséhez, illetve az államok feletti dominanciájához vezet. Ezt a logikát vélik alátámasztottnak akkor is, amikor a hagyományosan állami monopóliumnak tartott katonai képességek is - bár különböző formákban, de - egyre több esetben jelennek meg a nem állami szereplők eszköztárában.

Nye végül arra a következtetésre jut, hogy sem a klasszikus realista, sem a liberális intézményi elmélet nem vizsgálja a nemzetközi rendszer szereplöi közötti kapcsolatok teljességét, így egyik sem ad komplex választ. A különböző szinteken megjelenő összefüggések együttes ismerete szükséges ahhoz, hogy a szereplők megértsék a rendszer egészét, felismerjék a trendeket és megfelelő döntéseket tudjanak hozni a rendelkezésre álló erőforrások hatékony alkalmazásáról. Véleménye szerint a 21. században a nemzetközi, illetve transznacionális kapcsolatok alakítása nem egyenlő 
azok ellenőrzésével, és az erősségek és gyengeségek ismeretében a hatalom megítélése az adott kontextustól függ. Ezt a megközelítést „liberális realizmus”-nak nevezi. (Nye 2011, p. 213)

Huntington sem vonta kétségbe a nemzetállamok létét és szerepét a nemzetközi rendszerben, amikor - más megközelítésben ugyan, de - szintén a transznacionális kapcsolatok fejlődésében találta meg a nemzetközi rendszer további fejlődésének lehetőségét. A fentiektől eltérően Huntington nem magukat a szereplőket tekintette meghatározónak, hanem azt, hogy tevékenységüket hol (legalább egy nemzetközi határon átnyúlóan) és milyen szinten (nem az állam egészét érintő módon) fejtik ki. Ez a meghatározás nem kérdőjelezi meg ugyan az államok szerepét, de egy egészen új dimenziót nyit meg a nemzetközi kapcsolatok vizsgálatában, amennyiben a korábbi állami és államok alkotta nemzetközi szervezetek szintjeit „,metsző”, több államot érintő, de azokat nem egészében lefedő tevékenységi területeket határoz meg. Bevezeti a kiegészítő konfliktus fogalmát, amelyben a szereplők - rendszerint egy állam és egy transznacionális szereplő - nem egymást kioltó, hanem egymást kiegészítő módon verseng egy adott tevékenység elvégzésekor vagy befolyás megszerzésekor. Bár Huntington 1973-ban még arra a következtetésre jutott, hogy az állami és a nem állami (transznacionális) szereplők nem hogy kizárják, épp ellenkezőleg feltételezik egymás létezését, megközelítése egy olyan új jelenségre világít rá, ami hosszú távon a befolyásért való küzdelemben egymás elnyomását célzó konfliktusokhoz is vezethet a különböző transznacionális szereplők között. (Huntington 1973)

\subsubsection{Transznacionális kapcsolatok 2.0}

A változó nemzetközi rendszerben az 1970-es években előtérbe került neoliberális megközelítés nem változtatta meg alapjaiban a nemzetközi kapcsolatok elméletét, nem történt meg a transznacionális kapcsolatok áttörése. Az 1990-es évektől azonban a kérdés új megközelítésben a korábbinál jelentősebb mértékben került a vizsgálat középpontjába.

A neoliberális elméletre építve mind nagyobb figyelmet kapnak az olyan új

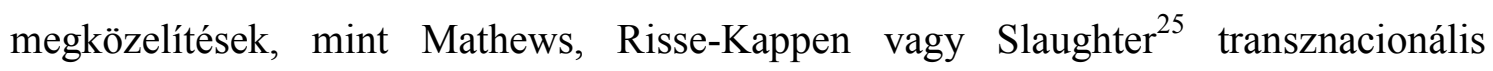

\footnotetext{
${ }^{25}$ Anne-Marie Slaughter gyakorló amerikai nemzetközi kapcsolatok szakértő. 2009 és 2011 között az amerikai Külügyminisztérium Tervezési Főosztályának vezetője volt. Azt megelőzően a Princeton
} 
kapcsolatokra épülő elméletei. Ezek az elméletek megkérdőjelezik a „nemzetközi kapcsolatok" államközi alapjait. Nem kérdőjelezik meg ugyanakkor az államok létét és szerepét, hanem kibővítik a vizsgálat körét olyan transznacionális interakciókra, amelyekben legalább az egyik fél nem állam. Ebben a kapcsolatrendszerben tehát állam és nem állami szereplő, illetve nem állami szereplő és nem állami szereplő kapcsolatáról beszélhetünk. A transznacionális szereplők a transznacionális társadalom szintjén, vagyis a „társadalmak világában” lépnek egymással kapcsolatba. Számos szerző „posztvesztfáliai” vagy „posztnacionális konstellációról” avagy „világtársadalom” kialakulásáról ír. (Kiss J. 2003, p. 33) Az államok feletti, melletti vagy alatti szinteken létrejövő kapcsolatok számának növekedését a kommunikáció fejlődésére és költségeinek csökkenésére, a nemzetközi közlekedés fejlődésére és a pénzügyi hálózatok globalizálódására vezetik vissza. A transznacionális kapcsolatok általánosan elfogadott definíciója - szemben az államok közötti kapcsolatot feltételező nemzetközi kapcsolatokkal - az lehetne, hogy: olyan államhatárokon átnyúló kapcsolatok, amelyekben legalább az egyik résztvevő fél nem állami szereplő.

A konstruktivista elmélet kereteit alkalmazva Thomas Risse-Kappen az, aki talán a legkiegyensúlyozottabb konklúziót vonta le, amikor úgy fogalmazott, hogy ,a transznacionális kapcsolatok számítanak a világpolitikában [...]. Az, állam világ” és a „társadalom világ” feltételezi egymás létezését.” (Risse-Kappen 1995, p. 310) A konstruktivista szemlélet elutasítja a neorealista felfogás alaptételét, hogy az anarchikus rend az államok közötti kapcsolatok alapja, és azt állítja, hogy az valójában az államok által kialakulni engedett rendszer. A rendszer sajátosságainak vizsgálatán túl a cselekvéseket meghatározó hatalmi viszonyokat helyezi a vizsgálat középpontjába. Tovább is lép annyiban, hogy az államok közötti kapcsolatokra épülő rendszert nem tekinti kizárólagosnak. Risse-Kappen vizsgálatának tárgyát a belső struktúrák és a nemzetközi intézmények képezték. Különös figyelmet fordított a szereplők közötti kapcsolatok minőségének elemzésére, és a kapcsolatok jellegének változására. Véleménye szerint ezek határozzák meg a transznacionális szereplők befolyásolási képességét a nemzetközi kérdésekben, mivel a hagyományos értelemben vett dominancia relativizálódik. Hangsúlyozta, hogy a - hazai és nemzetközi - kormányzati szerkezet és a nem állami szereplők közötti kapcsolatok empirikus tanulmányozása adhat valódi választ a nemzetközi kapcsolatok alakulásának kérdésére, és nem az állami

University Woodrow Wilson School tanára, illetve dékánjaként tevékenykedett. A Council on Foreign Relations tagja. 
és nem állami szereplők nemzetközi kapcsolatokra gyakorolt hatásának összehasonlítására vonatkozó elméleti vita, ami amúgy is eredménytelennek bizonyul. A nemzetközi szervezetek szerepét fontosnak tartotta, mert rajtuk keresztül valósul meg a transznacionális kapcsolatok egy része. A nem állami szereplők befolyásolási képességének növekedéséhez - amint arra a későbbiekben részletesen kitérek hozzájárulnak a nemzetközi szervezetek, amennyiben a hozzájuk való könnyebb hozzáférés lehetőséget teremt a nem állami szereplök számára az államok közvetett befolyásolására.

Bár elfogadom Risse-Kappen következtetését, hogy a belső struktúrák és a nemzetközi intézmények magyarázzák a nem állami szereplők érdekérvényesítési képességét, nem fogadom el azon megállapítását, hogy azok jobban magyarázzák azt, mint maguk a nem állami szereplők, illetve a tevékenységi területek tulajdonságai. Utóbbiak a 21. század fejlődési irányait figyelembe véve a korábbinál nagyobb szerepet kaphatnak, amit később ismertetek.

A transznacionális elmélet szereplők szerinti vizsgálatának ,állami” vonatkozásait emelte ki Krasner, ${ }^{26}$ aki hangsúlyozta, hogy ezek a nem állami kapcsolatok definíció szerint - amint azt a definíciós probléma tárgyalásánál is láttuk - feltételezik az államok, vagy azoknak megfelelő politikai egységek létezését. (Krasner 1995) A transznacionális szereplők, amelyek egyben nem állami szereplők is, müködésük során egyrészt alkalmazkodnak a meglévő politikai struktúrákhoz, másrészt azokon keresztül igyekeznek befolyásolni a döntéshozatali folyamatokat. Az interakciók során értelemszerűen nemcsak a nem állami szereplők hatnak az állami szereplőkre, hanem az állami szereplők is hatnak - tevőlegesen vagy passzív módon - a nem állami szereplökre.

Az államok Krasner felfogásában egyrészt egy intézményrendszert jelentenek, másrészt egy döntéshozatali központot. A realista felfogással szemben a „döntéshozatali központ” megközelítés azt hangsúlyozza, hogy a nemzetközi kapcsolatok alakításának az állam már nem kizárólagos szereplője, hanem a különböző szereplők befolyásolási törekvéseinek színtere. Bizonyos témákban nem akarja, bizonyos esetekben pedig nem tudja befolyásolni a becsatornázott érdekek eredőjeként kialakuló nemzetközi folyamatokat - legyen szó például információk, személyek vagy ideológiák

\footnotetext{
${ }^{26}$ Stephen D. Krasner a Stanford University nemzetközi kapcsolatok professzora. Fő kutatási területe az állami szuverenitás. 2005 és 2007 között az amerikai Külügyminisztérium Tervezési Főosztályának vezetöje volt.
} 
áramlásáról. Más kérdésekben erősíti a nem állami szereplők kezdeményezését, esetenként pedig maga ösztönzi a nem állami aktivitást, vagy annak nemzetközi megnyilvánulását: termékek exportja, külföldi tőke beáramlása, egyebek. A nem állami szereplők a transznacionális csatornákon keresztül az állami magatartáshoz alkalmazkodva, avagy azt alakítva határozzák meg saját érdekérvényesítési stratégiájukat, kötnek szövetségeket, alakítanak ki hálózatos együttmüködéseket. Bizonyos témákban a fentieknek megfelelően ellenállás nélkül érhetik el céljaikat, más kérdésekben konfrontálódniuk kell.

$\operatorname{Minc}^{27}$ „új középkorról” írt, amikor a hidegháború utáni nemzetközi rendszert jellemezte. (Minc 1993) Felfogása szerint a nemzetközi rendszer szervezettsége megbomlott, a hagyományosnak tekinthető rendezőelvek nem érvényesülnek. A nemzetközi rendszer azonban nem süllyed anarchiába, nem marad meg ebben a „rendezetlen” állapotban, mivel idővel új rendezőelvek kialakulása várható.

Mathews „Új középkor” elmélete, ${ }^{28}$ a nemzetközi rendszer szereplőit vizsgálta. (Mathews 1997) Aktorközpontú megközelítése egészen odáig ment, hogy a felmerülő új nemzetközi problémákat már nem az államok fogják tudni leghatékonyabban megoldani. Helyüket átadják a nem állami szereplőknek, amelyek az állami szint alatt, felett vagy helyett jelennek meg. Az elmélet szerint a korábban egy-egy területen megjelenő nem állami szereplők olyan mértékü befolyásra tesznek majd szert, hogy a mind nagyobb részt globálissá - de legalábbis transznacionálissá - váló problémák kezelésére alkalmasabbakká válnak, mint a nemzetállamok, amelyeket a közel 400 éve fennálló vesztfáliai rendszer alapvető és meghatározó szereplőinek tekintettek a korábbi elméletek. A különböző államközi együttmüködési formák, államok feletti nemzetközi szervezetek, transznacionális hálózatokba szerveződő államok alatti NGO-k és transznacionális gazdasági szereplők egy időben egymás mellett léteznek. A különböző szereplők hálózatai egymást is átfedő globális hálózattá alakulnak. A nemzetközi aktorok ebben a globális hálózatban próbálnak érvényt szerezni érdekeiknek. Kialakul az egyének többes lojalitása, és a nem állami szereplők államokkal szemben történő meghatározása is háttérbe szorul. Az érdekérvényesítés új formáiról ebben a hálózatos rendszerben később részletesebben értekezem.

\footnotetext{
${ }^{27}$ Alain Minc neves francia üzletember, Eduard Balladure és Nicolas Sarkozy politikai tanácsadója. Az Institute Nicolas Berggruen tagja.

${ }^{28}$ Az ,új középkor” elmélet alapjait lásd még David Held (1991): Democracy, The Nation-state, and the Global System, és Hedley Bull (1977): The Anarchical Society: a Study of Order in World Politics címü írásaiban.
} 
Az „új középkor” elmélet speciális gazdasági aspektusaiból kiindulva Reinicke ${ }^{29}$ abba az irányba lépett tovább, hogy a nemzetközi kormányzás fogalmát választotta el az államtól. Az egyes szabályozandó területek esetében azt vizsgálta meg, hogy azt milyen szinten - lokális, regionális, állami, vagy nemzetközi - és mely szereplő képes megfelelő módon megvalósítani. (Reinicke 1998) Reinicke nem vonta kétségbe az államok létét vagy szerepét, de elismerte, hogy a növekvő számú és szervezettségű nem állami szereplő mind nagyobb mértékben képes befolyásolni a transznacionális politikákat és döntéshozatali folyamatokat. A különböző nem állami szereplők egyszerre igyekeznek alakítani egymást és az államokat, lobbiznak, nyomást gyakorolnak, együttmüködnek vagy konfrontálódnak - függően attól, hogy az adott helyzet milyen magatartási formát kíván meg. ${ }^{30}$

„A neomedievalisták szerint az NGO-k nemzetközi kapcsolatokban játszott szerepének növekedése igen pozitív szerepet játszik a globális „civil társadalom” kialakulásában. [...] Az erősödő nemzetközi civil társadalom valószínüleg erős politikai érdekeltségek körül szerveződő hazai és transznacionális csoportokból fog állni,” (Gilpin 2004, p. 394) de az elmélet egyelőre még nem tud egyértelmű és átfogó választ adni arra a lényeges kérdésre, hogy ezek a csoportok mely területeken bírnak majd az államokéhoz mérhető, vagy azt meghaladó befolyással. A nemzetközi rendszer befolyásolási képességének területeit - a teljesség igénye nélkül - a vonatkozó fejezetben vizsgálom majd meg.

Slaughter transzgovernmentalizmus elmélete - mint a neve is utal rá - szintén nem vetette el az államok létezését, ám kiemelt szerepet szánt a nem állami szereplőknek. A kormányzást az állami funkciók elkülönítésével, és az egyes kormányzati funkciók megfelelő keretben történő kezelésével tartotta hatékonyan megvalósíthatónak. Az állam, mint a kormányzást megvalósító szereplő tehát megmarad, de a kormányzat egyes részei önálló aktorként jelennek meg a nemzetközi kapcsolatokban. (Slaughter 1997) A kormányzat részeinek önálló aktorként való megjelenése hatással van a

\footnotetext{
${ }^{29}$ Wolfgang H. Reinicke a Central European University dékánja, korábban a Brookings Institution tudományos munkatársa volt. A UN Global Compact kezdeményezésben részt vevő berlini Global Public Policy Institute társalapítója és igazgatója.

${ }^{30}$ Kobrin ugyanakkor amellett érvelt, hogy a világgazdaság digitalizálódásának következtében a földrajzi értelemben vett határokkal körülvett állam alapvetően elveszíti jelentőségét. A kibernetikai hálózatok, a helytöl független kibertér határokon átnyúlva, azokat figyelmen kívül hagyva egy új államok feletti vizsgálati egységet hoznak létre. (Kobrin 1998) Khanna pedig egészen odáig megy, hogy párhuzamot von a 21. század nemzetközi szereplői és a 12. század szereplői között, amennyiben a nem állami szereplők, a magánhadseregek, a hálózatok, illetve közösségek meghatározó szerepet játszanak az államok mellett vagy rovására. (Khanna 2009) Még ha az analógia nem is tökéletes, jó példája annak, hogy a nem állami szereplök milyen rég óta aktív tagjai a nemzetközi közösségnek.
} 
nemzetközi rendszer hatalmi struktúrájára, ami ennek megfelelően átalakul: a hierarchikus viszonyoktól a hálózatok felé mozdul el. A kényszerítő hegemón hatalmat a vonzás hatalma, az együttmüködésre való törekvés váltja fel. Az államok együttmüködése helyett a globális kormányzás hálózatok formájában történő megjelenése válik meghatározóvá.

A transzgovernmentalizmus elmélete épít a neofunkcionalista irányzatra, amely ugyanezen folyamatokból elsősorban az államok növekvő diszfunkcionalitását emeli ki, és a nem állami szereplők növekvő számát alapul véve azok növekvő szerepvállalását, a világtársadalom megteremtését tekinti az új - együttmüködésre épülő - politikai világrend kialakítása zálogának. Slaughter azonban nem megy ennyire messze. Az általa definiált „új világrendben” a nemzetközi szervezetek szerepének növekedése mellett nem a nem állami szereplők hálózatainak megerősödését, hanem a kormányok együttműködésének hálózatosodását, „kormányközi hálózatok” létrejöttét vetíti előre, amibe a nem állami szereplők a korábbinál hatékonyabb módon tudnak bekapcsolódni. A kormányközi, illetve a transznacionális hálózatok elsősorban liberális demokráciák között alakulhatnak ki, mivel ezek rendelkeznek azokkal az intézményi struktúrával, amiben a hálózatok müködése biztosított lehet. Ugyanakkor, amennyiben sikerül bekapcsolni valamely hálózat tevékenységébe egy nem-demokratikus állam intézményét, akkor ezen keresztül magának az államnak a demokratikus működés irányába történő előrelépését is elő lehet segíteni.

A nemzetközi együttmüködésnek ez a formája erősítené a nemzetközi szervezeteket, ugyanakkor kellő flexibilitást hagyna az államoknak a számukra legkedvezőbb részvételi formák kiválasztásában. Megoldást kínálhatna azon transznacionális problémák megoldására, amelyeket az államok külön-külön nem képesek kezelni, mégsem jelentene túlzott és végleges kötelezettségvállalást részükről. Az egyes hálózatok résztvevői köre nem feltétlenül esne egybe, vagyis az államok - a nem állami szereplök tematikus rendeződéséhez hasonlóan - azokon a területeken müködhetnének együtt, amelyeken annak szükségét érzik. Az állami szuverenitás részekre bontódna, ugyanakkor nem szünne meg. A nem állami szereplők részt vehetnek az egyes hálózatok tevékenységében, a nemzetközi szervezetek pedig lefedhetik azokat, vagy részét képezhetik azoknak. A kormányzatok alacsonyabb egységekre történő felbomlásából és a hálózatok müködési mechanizmusaiból adódóan Slaughter elmélete magában hordozza annak a lehetőségét is, hogy a nem állami szereplők 
megerősödésével a hálózatok tevékenységét egyre nagyobb mértékben lesznek képesek befolyásolni az államokon túl a nem állami szereplök is.

Összefoglalóan megállapíthatjuk tehát, hogy amíg a realista iskola a hatalomért folytatott küzdelem alapján a létező nemzetközi rendszert igyekszik leírni és megmagyarázni, addig a liberális iskola arra próbál meg választ adni, hogy hogyan lehetne elkerülni a konfliktusokat, és milyennek kellene lennie egy ideális világnak. Míg Hobbes vagy Morgenthau arról írt, hogy az ember természeténél fogva hogyan követi egyéni érdekeit, és az államok adottságaiktól vezérelve hogyan próbálják elérni céljukat a rendelkezésre álló eszközökkel, addig Kant vagy Keohane arra kereste a választ, hogy milyen együttmüködési formákon keresztül, milyen új eszközökkel vagy intézményekkel lehet megteremteni az államok közötti békés egymás mellett élés és együttmüködés feltételeit. Míg Churchill vagy Reagan azon fáradozott, hogy hogyan győzze le az ellenséget, Wilson pontokba szedte, hogy milyennek kellene lennie az ideális világnak ahhoz, hogy elkerüljük, vagy békés úton megoldjuk a konfliktusokat.

A nem állami szereplök vizsgálatakor nem hagyhatjuk teljesen figyelmen kívül a realista és a liberális megközelítést sem, „a „szisztemikus”, struktúraalapú és a „szubszisztemikus”, aktoralapú megközelítések ugyanis számos esetben keresztezik a realizmus versus liberalizmus megosztottságot. A realizmus és a neorealizmus kettőssége jól mutatja, hogy egyetlen elméletcsaládon belül is lehetségesek a struktúraalapú, „szisztemikus” és aktoralapú, „szubszisztemikus” elméletek. A neorealizmus versus neoliberalizmus megosztottság sem azonosítható csak a „szisztemikus” versus „szubszisztemikus” különbségtétellel, mivel mind a neorealizmuson, mind a neoliberalizmuson belül létezik a strukturális perspektíván alapuló, „,szisztemikus” megközelítés. A realista elméleten belül lehetséges a szervezeti magatartás szubszisztemikus megközelítése, míg a neoliberalizmuson belül az interdependencia-elmélet szisztematikusnak tekinthető, s a szociálkonstruktivista perspektíva mind a társadalmi, mind a transznacionális szocializációval kapcsolatban állhat.” (Kiss J. 2009, p. 83)

A nem állami szereplök helyének és befolyásának vizsgálata során a nemzetközi rendszerben végbemenő változásokat figyelembe véve a transznacionális kapcsolatok vizsgálata kínálja a legjobb kiindulási pontot, bár az szolgál legkevésbé koherens elméleti háttérrel.

Elemzésem során a transznacionális kapcsolatok elméletéből indulok ki. A rendszer mozgatórugójának tekintett hatalom vizsgálatakor Keohane és Nye megközelítését 
veszem alapul. A vizsgálódás során elsődlegesen a rendszer szintjén, annak többi elemével való interakcióira vonatkozó, „szisztemikus” elemzést kívánok adni, aminek fontos része a befolyás érvényesítése különböző szintjeinek vizsgálata. Ugyancsak lényeges maguknak a nem állami szereplőknek, mint az állami szint alatt/mellett/felett megjelent növekvő befolyású aktoroknak a vizsgálata abszolút és relatív képességeik alakulása szempontjából. A rendszer szereplők szempontjából történő elemzésénél Matthews „új középkor” elméletéből indulok ki, ami szerint - mint fentebb említettem a felmerülő új nemzetközi problémákat már nem az államok fogják tudni leghatékonyabban megoldani. Helyüket átadják a nem állami szereplőknek, amelyek az állami szint alatt, felett vagy helyett jelennek meg. A nemzetközi rendszer szereplői közötti kapcsolatok vizsgálatakor elsősorban Risse-Kappen elemzési keretét fogadom el, kiegészítve azt speciálisan a kormányzati funkciók átvételének vizsgálatakor Slaughter megközelítésével. A vizsgálat választ kíván adni arra, hogy ezen elmélet mentén valóban érzékelhető-e, illetve magyarázható-e a nem állami szereplők növekvő befolyása, és ha igen, mely területeken érheti el vagy haladhatja meg az államok befolyását. 


\section{FEJEZET}

\section{A NEMZETKÖZI KAPCSOLATOK VÁLTOZÁSAI}

Mindenekelőtt át kell tekintenünk a nemzetközi kapcsolatok rendszerének jelenleg is folyó változásait annak érdekében, hogy meg tudjuk határozni azt értelmezési keretet, ahol a nem állami szereplők tevékenységét vizsgáljuk. A nemzetközi kapcsolatok határai folyamatosan változnak, a hagyományos kapcsolatokon túl megjelennek, és egyre nagyobb jelentőséggel bírnak a transznacionális kapcsolatok. Mint fentebb tisztáztuk, transznacionális az a határokon átnyúló kapcsolat, amelyben legalább az egyik résztvevő nem állam, illetve ami egy vagy több államhatáron átnyúló tevékenység során alakul ki, függetlenül attól, hogy az állam szintjén, avagy az alatt történik-e. A vesztfáliai rendszer középpontjában álló nemzetállamok alatti (szubnemzeti) szint megerősödése egyszerre következménye és előidézője az állami szint gyengülésének.

A nemzetközi vagy transznacionális kapcsolatok meghatározó eleme a hatalom, hiszen az interakciók többsége valamilyen formában a hatalomért folyó küzdelem megnyilvánulása. Ebböl következik, hogy a hatalom definícióját, és a nem állami szereplők sajátosságaiból adódóan annak összetevőit is részletesen meg kell vizsgálnunk ahhoz, hogy megértsük az egyes szereplők egymáshoz való viszonyainak alakulását. A változások dinamikájából adódóan érdemes kitérni az alkalmazkodás szükségszerüségére, és a nemzetközi szereplők alkalmazkodási képességére.

\subsection{A határok megváltozása}

A nemzetközi kapcsolatok határai átalakultak, a nemzetközi kapcsolatok szférái kibővültek a szupranacionális problémák, transznacionális kihívások és a belpolitika „külpolitizálódása” hatására. Az államközi kapcsolatok már nem tekinthetőek a nemzetközi kapcsolatok kizárólagos vagy elsődleges viszonyrendszerének, és nem képesek egyedül meghatározni a nemzetközi kapcsolatok alakulását. Újra kell definiálni a nemzetközi kapcsolatokban részt vevő aktorok körét és egymáshoz viszonyított helyzetét. A nemzetközi rendszer szereplői között a kapcsolatok új formái alakultak ki. A szigorúan értelmezett államok közötti nemzetközi kapcsolatok mellett megjelentek a transznacionális kapcsolatok, valamint a globális kapcsolatrendszerek. Egyszerre 
lehetünk tanúi a belpolitika „külpolitizálódásának”, a külpolitika „,belpolitizálódásának”, illetve a kül- és belpolitika szimbiózisának. A kül- és belpolitika egymástól elkülöníthető területek maradnak, de a nemzetközi kapcsolatok alakítása során egyre kevésbé különülnek el. A kihívások egyre gyakrabban a kül- és belpolitika, mint két végpont közötti kontinuumban jelennek meg, és értelemszerüen azokra arra adandó válaszok is ebben a térben kell, hogy megszülessenek. (Kiss J. 2009)

A hatalom, mint a befolyásolás képessége különböző szinteken jelenik meg, amelyeken az egyes aktorok különböző mértékben képesek érdemben jelen lenni. Sőt a globalizáció hatására kialakult interdependenciák jelentőségének növekedése ezeket a kapcsolatrendszereket felértékelte, és olyan állami és nem állami szereplők között hozott létre függőségi viszonyt, és ezáltal befolyásolási lehetőséget, vagyis hatalmi viszonyt, amelyek földrajzi vagy politikai okok miatt korábban nem voltak egymással kapcsolatban. Ezáltal a hatalmi viszonyok mennyiségileg is és minőségileg is megváltoztak, a korábbinál jóval összetettebb rendszert hívva életre. Míg korábban a nemzetközi kapcsolatok egyik - ha nem a - legfontosabb eszköze a kényszerítés hatalma volt, addig ma már egyértelmüen kimutatható a vonzás hatalma fontosságának felismerése. Előbbi mindenekelőtt a katonai hatalomra épül, kisebb mértékben a gazdasági érdekérvényesítés konfrontatív elemeire, addig utóbbi a gazdasági kapcsolatok együttmüködést feltételező eszközrendszerét, valamint más társadalmi kapcsolatokat használ a célok eléréséhez. Ez az eltolódás nagyrészt annak köszönhetö, hogy a nemzetközi rendszerben egyre több korábban háttérbe szorult terület tesz szert növekvő jelentőségre.

A TNC-k tevékenységének kiterjedése, a gazdasági és kereskedelmi kapcsolatok intenzitásának növekedése, valamint ezek hatása az egyes országok gazdasági, társadalmi és ezen keresztül politikai viszonyaira közvetlen kapcsolatot teremtettek a vállalatok és a befogadó országok között. A transznacionális nem állami szereplők mind több területen találták meg, és találják meg várhatóan a jövőben is, a döntéshozatal befolyásolásának lehetőségét. Ennek mára már klasszikus példájává vált többek között a környezetvédelem vagy éppen az emberi jogok területe. Bővebb társadalmi-politikai kontextusban a politikai pártok térvesztése a nemzeti politikai rendszerekben a társadalmi-gazdasági érdekcsoportok és érdekszerveződések megerősödésével jár. (Magone 2011, Goetz et al. 2009) Ez is hozzájárul a szubnemzeti nem-állami szereplők állami szint feletti térnyeréséhez. Kevesebb figyelmet kapnak, de elítélendő tevékenységük ellenére sem hagyhatók figyelmen kívül a nemzetközi szervezett 
bűnözői csoportok vagy terrorista szervezetek, amelyek a hagyományos államhatárokat figyelmen kívül hagyva müködtetik hálózataikat és hajtják végre akcióikat, ezen keresztül fejtve ki befolyásukat.

A kommunikáció fejlődése és a média globalizálódása hatására a korábban helyi vagy nemzeti szinten értelmezett közvélemény egy magasabb szinten, a világtársadalom szintjén alakult újjá. A világtársadalom érdeklődése egyrészt kiterjed olyan kérdésekre, amelyek csak szupranacionális szinten oldhatóak meg, illetve amelyekre ezen a szinten hatékonyabb válasz adható. Másrészt foglalkozik olyan problémákkal is, amelyek ugyan lokálisak, de a világ számos pontján előfordulnak, így az érintettek virtuális közösségén belül érdeklődésre tarthatnak számot. De sok esetben egy adott probléma annak forrásától, földrajzi helyétől függetlenül, illetve attól távol is olyan érzelmi reakciókat válthat ki, amelyek cselekvésre ösztönöznek más szereplőket.

Ezeken túl még említést érdemelnek azok a mesterségesen gerjesztett problémák is, amelyek egyszerüen kínálatukkal megteremtik a saját keresletüket, létrehozzák a világtársadalom vonatkozó reakcióját. Egy téma globális felértékelődésének egyik legfontosabb feltétele a téma artikulációjának képessége. Ennek lehetőségét a technikai fejlődés, a globális média kialakulása és a különböző társadalmi hálózatok kialakulása teremtette meg.

\subsection{A hatalom gyakorlásának változása}

A nemzetközi szereplőket körül vevő környezet alakulásával megváltozott az érdekek érvényesítésének lehetősége, a különböző szintü döntéshozatali folyamatok befolyásolási képessége, vagyis a hatalom fogalma. A befolyásolási képesség gyakorlását nehéz meghatározni. Könnyebb annak eszközeit vagy megnyilvánulásait meghatározni. Ahogyan Nye szemléletesen megfogalmazta, a hatalom olyan, mint a szerelem, könnyebb megtapasztalni, mint meghatározni. A hatalom megnyilvánulásáról ugyanakkor más-más felfogások léteznek. Machiavellit követve gondolkodhatunk úgy, hogy a „fejedelem” (vagyis ma már szélesebb értelemben a nemzetközi szereplő) célja a hatalom megszerzése és megtartása elsődlegesen a katonai erőre támaszkodva, mivel jobb, ha a nemzetközi szereplők katonai képességei miatt félnek tőle, mint ha a vonzás hatalma miatt szeretik.

A mai globalizálódó, földrajzi és demográfiai szempontokat mindinkább nélkülözni tudó nemzetközi rendszerben sokkal inkább építhetünk a smart power koncepciójának 
részét képező soft power elemekre ${ }^{31}$, és igyekezhetünk kiépíteni az önszántukból együttmüködő szövetségesek hálóját. Amennyiben elfogadjuk a hálózatokból felépülő világ képét, úgy a hatalmat nem is, mint az ellenőrzés képességét, hanem mint az összehangolás tudományát kell szemlélnünk. A hatalom különböző definíciói e végletek között szóródnak.

George W. Bush első ciklusában Machiavellit követte, amikor szinte kizárólagosan a katonai erőre építette az Egyesült Államok hatalmát. Barack Obama ugyanakkor sokkal inkább épített a smart power koncepciójának részét képező soft power elemekre, és igyekezett visszaállítani az amerikai álom vonzerejét, az önszántukból együttmüködő szövetségesek hálóját. Az Egyesült Államok mindvégig a hatalom mindkét összetevőjével rendelkezett, de azokat különböző mértékben aknázta ki.

A hatalom definíciójaként elfogadhatjuk Dahl ${ }^{32}$ megfogalmazását, miszerint hatalom az a képesség, hogy másokat olyan cselekedetre késztetünk, amelyet maguktól nem tennének meg. (Dahl 1961) Nye megfogalmazását azonban pontosabbnak tartom, amely szerint „a hatalom mások viselkedése befolyásolásának képessége saját célunk elérése érdekében." (Nye 2004, p. 10) Ugyanakkor ma már azt is hatalomnak tekintem, ha annak az információnak a birtokában vagyunk, hogy valamely szereplő magatartása hozzájárul célunk eléréséhez, ezáltal szükségtelenné téve viselkedése befolyásolását. Ez azért különösen fontos, mert a nemzetközi kapcsolatok szereplöinek a száma folyamatosan nő, a nemzetközi nem állami szereplők száma meredeken emelkedik, ami szinte lehetetlenné teszi a szereplők nagy része magatartásának befolyásolását. Teljes definíciónak mindezek alapján azt tekintem, hogy „a hatalom mások viselkedése következményeinek ismerete, és viselkedése befolyásolásának képessége saját célunk elérése érdekében".

A hatalom típusait Nye három csoportra osztja:

\footnotetext{
${ }^{31}$ A smart power a soft power (érték alapú vonzás hatalma/puha hatalom) és a hard power (kényszerítő erő) kombinációja. Részletesebben ír erröl Szörényi (2009).

${ }^{32}$ Robert Alain Dahl a 20. század egyik meghatározó amerikai politikatudomány professzora. A Yale Egyetem professzor emeritus-a, az Amerikai Politikatudományi Társaság korábbi elnöke. Munkásságának kiemelkedő hozadékaként tartják számon a hatalom definíciójának megalkotását.
} 
1. ábra: A hatalom típusai Nye szerint

\begin{tabular}{|c|c|c|c|}
\hline & $\begin{array}{l}\text { Viselkedési } \\
\text { forma }\end{array}$ & $\begin{array}{l}\text { Elsődleges } \\
\text { eszközök }\end{array}$ & $\begin{array}{l}\text { Kormányzati } \\
\text { politikák }\end{array}$ \\
\hline $\begin{array}{l}\text { Katonai } \\
\text { hatalom }\end{array}$ & $\begin{array}{l}\text { kényszerítés, } \\
\text { elrettentés, } \\
\text { védelem }\end{array}$ & $\begin{array}{l}\text { fenyegetés, } \\
\text { erő }\end{array}$ & $\begin{array}{l}\text { kényszerítő } \\
\text { diplomácia, } \\
\text { háború, } \\
\text { szövetség }\end{array}$ \\
\hline $\begin{array}{l}\text { Gazdasági } \\
\text { hatalom }\end{array}$ & $\begin{array}{l}\text { ösztönzés, } \\
\text { kényszerítés }\end{array}$ & $\begin{array}{l}\text { kifizetések, } \\
\text { szankciók }\end{array}$ & $\begin{array}{l}\text { segély, } \\
\text { juttatások, } \\
\text { szankciók }\end{array}$ \\
\hline $\begin{array}{l}\text { A vonzás } \\
\text { hatalma } \\
\text { (soft power) }\end{array}$ & $\begin{array}{l}\text { vonzás, } \\
\text { tematizálás }\end{array}$ & $\begin{array}{l}\text { értékek, } \\
\text { kultúra, } \\
\text { politikák, } \\
\text { intézmények }\end{array}$ & $\begin{array}{l}\text { társadalmi } \\
\text { diplomácia, } \\
\text { kétoldalú } \\
\text { multilaterális } \\
\text { diplomácia }\end{array}$ \\
\hline
\end{tabular}

A gazdasági hatalom jelentőségét jól mutatja, hogy az amerikai védelmi minisztérium 2009-ben első alkalommal szervezett ,gazdasági hadgyakorlatot”, amelyben azt szimulálták, hogy egy nemzetközi gazdasági háború során a különböző pénzügyi nem állami szereplők (befektetési bankok, fedezeti alapok, pénzügyi befektetők) lépései hogyan hatnak az Egyesült Államok gazdaságára. A globális tőkeáramlás kihatásai azért is fontosak, mert egy pénzügyi és/vagy gazdasági válság következményeként összeomolhatnak államok, ami globális gazdasági és politikai instabilitáshoz vezethet. A gazdasági hatalom soft power elemeinek egyik legjobb példája az európai integráció folyamata, vagyis az EU által képviselt gazdasági jólét vonzerejének megnyilvánulása. Erről az EU-csatlakozásra való készülés példáján keresztül korábban sok szó esett Magyarországon is. A gazdasági modell, illetve a gazdasági jólét jelentette vonzerő egyszerre generált gazdasági, társadalmi és ezen keresztül politikai érdekeket, és biztosította, biztosítja azt, hogy a jólét és biztonság térségéhez tartozni kívánó országok önként vállalják az alkalmazkodást, a szabályozások önmagukra kötelezőként való elfogadását. Anélkül, hogy a szuverenitás megosztásának vagy átruházásának politikaelméleti problematikájába részletesen belemennénk, mindenképpen érdemes 
megragadni a kérdésnek azt az aspektusát, hogy az EU-hoz való csatlakozás hatással van az államok szuverenitására és a nem állami szereplők érdekérvényesítési képességére. Előbbiek hajlandóak elfogadni ezt a korlátozást, míg utóbbiak kimondottan lelkesen élnek ezzel a bővülő lehetőséggel.

A vonzás hatalma különösen most érdemel figyelmet, mivel a 2008-ban kirobbant pénzügyi és gazdasági válság kapcsán megkerülhetetlenné vált a kérdés, hogy a szabadpiaci kapitalizmus amerikai, illetve euro-atlanti modelljének megítélése milyen mértékben szenved csorbát, és milyen következményekkel jár. Altman ${ }^{33}$ szerint az Egyesült Államok és Európa a pénzügyi és gazdasági krízis eredményeként elveszíti gazdaságpolitikájának, illetve általánosságban az általuk képviselt globális piacgazdasági modellnek a hitelességét. A pénzügyi rendszer összeomlása, a szabályozás elégtelensége a világ oly sok táján vonzónak tartott rendszer alapértékeit kérdőjelezi meg. (Altman 2009) Ez kérdésessé teheti a gazdasági értékválasztást több ingadozó társadalomban. A világ több országában ugyanis nemcsak a gazdasági válság közvetlen hatásai miatt, hanem a gazdasági modellbe vetett hit megszünése miatt is kritikusabban fogják megítélni a nyugati erőközpont modell-értékét. Mind az amerikai, mind az európai kormányok többsége a pénzügyi szektorban olyan mértékü beavatkozásokat hajtott végre, ami élesen ellentmond a modern kapitalizmusról alkotott képnek.

Ahogyan az erőforrások beszükülésével e két gazdasági egység veszíteni fog globális jelentőségéből, és a világ vonzási központjának áthelyeződése az euro-atlanti térségből felgyorsul, ugyanúgy elképzelhető, hogy az erőforrások beszűkülése a nem állami szereplők tevékenységét, fennmaradási és müködési képességét is veszélybe sodorja. Ráadásul a vonzó gazdasági helyzet és gazdasági modell, mint soft power eszköz megszünése gyengíti az érdekérvényesítési képességüket a globális gazdasági és politikai rendszerben. Olyan országok, mint például Kína a korábbinál nagyobb globális szerephez juthatnak. Kína az 1970-es évek végén elindult reformidőszak eredményeként rendkívül látványos fejlődést és növekedést produkált. Ennek eredményeként meghatározó súlyú és befolyású regionális hatalommá vált, amely mára már joggal tart igényt globális szerepvállalásra is. (Jordán 2007) Bár a válság Kínát is érintette, gazdasági növekedése némileg lelassult, de relatív elszigeteltsége, hatalmas belső piaca és óriási tartalékai miatt a gazdasági válság hatásai jóval kisebb mértékben gyürüztek be

\footnotetext{
${ }^{33}$ Roger Charles Altman amerikai befektetési bankár, korábbi pénzügyminiszter-helyettes. A Lehman Broters és a Blackstone Group munkatársa, az Evercore Partners alapítója.
} 
a kínai gazdaságba. Gazdasági növekedése a lassulás ellenére is az egyik legmagasabb maradt világviszonylatban, pénzügyi rendszere stabil maradt, és valutatartalékai mára megközelítőleg elérik a 3000 milliárd USD-t. Relatív értelemben erősödő gazdasági pozíciója várhatóan tovább fogja fokozni a kínai szerepvállalást a nem állami szereplők tevékenysége pénzügyi támogatásában. Ez felveti azt a kérdést, hogy a Kína, Oroszország, illetve más országok által képviselt erős állam koncepció mennyiben enged teret ezeknek a szereplőknek. További vizsgálatra érdemes az is, hogy az állam szerepe koncepciójának bizonyos térségekben jelenleg megfigyelhető erősödése hogyan lesz összeegyeztethető a nem állami szereplök tevékenységének fokozódásával. Összeütközésbe kerül-e a két folyamat, és ha igen milyen időtávon?

A gazdasági hatalom mellett a soft power egyéb fajtáinak jelentősége is nagymértékben változik, változhat. Amennyiben az információs forradalom gazdasági és szociális kihatásai a korábbiakhoz hasonló mértékben alakulnak, úgy a soft power eszközök összessége is egyre nagyobb szerepet kap a hatalmi-mixben.

A soft power több forrásból származhat: egy ország kultúrájából, amely vonzó mások számára, politikai értékeiből, amelyek követendő például szolgálhatnak, illetve külpolitikájából, amennyiben az morális autoritással bír. Az állami szereplők által eddig és jelenleg általánosságban használt eszköztár - amelyet meg kell különböztetnünk az államok által birtokolt eszköztártól - elsősorban a katonai képességekre és a gazdasági hard power eszközökre támaszkodott. Az államok kevesebb figyelmet fordítottak a gazdasági kapcsolatok soft power elemeire illetve más soft power elemekre, és a nemzetközi társadalmi kapcsolatok alakítására. A nemzetközi közvélemény érdeklődésének tematizálása, a nemzetközi intézményrendszer alakítása ugyancsak a soft power eszközökhöz sorolható.

A gazdasági hatalmat bizonyos értelemben hard power más tekintetben soft power eszköznek lehet tekinteni. Ha a gazdasági érdekérvényesítés szankciók formájában jelenik meg, akkor a kényszerítés hatalmáról beszélhetünk, ugyanakkor ha egy vonzó gazdasági modell, vagy a gazdasági jólét indukálta közeledés vagy minta-követés formáját ölti, akkor egyértelmüen a vonzás hatalmáról beszélhetünk. Ez utóbbinak vitathatatlanul egyik legjobb példája a fent említett Európai Unióhoz való csatlakozás szándéka által hajtott szabálykövetés és politikai, jogi igazodás a csatlakozni kívánó országok részéről. A lakosság körében végzett felmérések jól mutatták, hogy az EU által megtestesített „,nyugathoz tartozás”, valamint a remélt gazdasági jólét kellően nagy társadalmi támogatást biztosított a szükséges intézkedések meghozatalához, a 
jogszabályok átvételéhez, az Európai Uniós tagságból adódó kötelezettségek felvállalásához.

A soft power nehezen definiálható és még nehezebben mérhető volta miatt, annak jelentőségét elsősorban a hiánya esetén felmerülő hátrányokkal, költségekkel lehet indirekt módon kimutatni. Ez lehet közvetlenül jelentkező, vagy csak áttételesen kimutatható hátrány. Kelly mutat rá az iraki beavatkozás kapcsán, hogy Bush úgy kezdte meg a háborút, hogy sem széles katonai koalíciót, sem ENSZ felhatalmazást nem sikerült biztosítania. Ennek két közvetlen következménye lett: az Amerika-ellenes érzelmek felerösödése valamint a magasabb háborús és újjáépítési költségek. (Kelly 2003)

Nem közvetlen módon, de egyértelmüen kimutatható az is, hogy amennyiben nem fordít egy nemzetközi szereplő kellő figyelmet vonzási hatalmának fenntartására politikai értelemben, annak ugyancsak megfizeti az árát. Konkrét példánál maradva, „ha az Egyesült Államok annyira népszerütlen egy országban, hogy Amerika-pártinak lenni belpolitikai öngyilkosság, akkor a politikai vezetők nem fognak segítséget nyújtani. [...] Pervez Musharraf elnök komplex problémával néz szembe, amikor egyszerre próbálja segíteni az Egyesült Államokat a terrorizmus elleni küzdelemben, és kezelni a választók Amerika-ellenes érzelmeit. [..] Japán esetében az Egyesült Államok széles elfogadottsága a közvélemény szemében hozzájárult ahhoz, hogy a hatalmon lévő elitek mindig folytassák az együttmüködést az USA-val.” (Nye 2004b, p. 16)

A koalícióépítésnek, illetve a nemzetközi szervezetek kereteiben való együttmüködésnek kézzel fogható haszna is van: egyrészt a terhek megosztása lehetővé válik, így a hatalmi-mix katonai és gazdasági összetevői kedvezőbben alakíthatóak, másrészt a morális elfogadottság is erősebb nemzetközi szinten, ami a vonzás hatalmát tovább erősíti. Az így kialakuló megfelelő hatalom kombináció lényegesen nagyobb befolyásolási képességet eredményez.

Amennyiben elfogadjuk Nye megállapításait a vonzás hatalma jelentőségének növekedéséről, és azt kiterjesztünk a 21. századi világrend minden szereplőjére, akkor jogosan számíthatunk a nem állami szereplők soft power bázisú hatalmának relatív növekedésére. Amint láttuk, a soft power több olyan forrásból származhat (kultúra, amely vonzó mások számára, politikai értékek, amelyek követendő például szolgálhatnak, illetve szakmai tudás, ami áttételesen morális autoritást biztosíthat), amellyel a nem állami szereplők ugyanúgy rendelkeznek, mint az államok. Bizonyos esetekben az is lehetséges, hogy a vonzás hatalmával jobban tudnak élni a nem állami 
szereplők, legyenek azok az államok alatti vagy feletti szinten. Előbbire jó példa lehet valamely kérdésben jelentős szakmai tudást felhalmozó, és nemzetközi elismertséget szerzett NGO, míg utóbbira az Európai Unió.

\subsection{A hatalmi-mix}

Természetesen nem új értelmezés, hogy a hatalom nem tekinthető homogénnek, hanem különböző elemekből összeadódó egység. Minden országnak, sőt minden nemzetközi szereplőnek ezekből az elemekből tevődik össze a hatalma, vagy befolyásolási képessége. Ugyanakkor a különböző szereplők hagyományosan más-más mértékben rendelkeznek az egyes hatalmi típusokkal. Az adott nemzetközi szereplő befolyásolási képességének összessége nem más, mint a különböző hatalmi típusok kombinációja. Az ideális kombinációt divatos kifejezéssel élve smart power-nek nevezzük.

A smart power kifejezés első alkalommal 2004 márciusában jelent meg Nossel $^{34}$ tollából a Foreign Affairs-ben. (Nossel 2004) A szerző a konzervatív külpolitikai gondolkodást állítja szembe a szerinte követendő progresszív, liberális internacionalista felfogással. Az elsődlegesen katonai eszközökkel operáló, unilaterális megközelítést állítja szembe a szövetségesekkel együttmüködésben kialakított liberális demokráciák globális rendszerével. Utóbbi - álláspontja szerint - végeredményképpen kiküszöböli a háborúkat. Javaslata arra a felismerésre épül, hogy míg a második világháborút követően az Egyesült Államokat világszerte győztesként ünnepelték, addig 60 évvel később olajra éhes elnyomóként tekintettek rá a világ számos térségében. Álláspontjából némi általánosítással - és értelemszerüen leegyszerüsítéssel megfogalmazható, hogy az együttműködésre való nyitottság, a nemzetközi intézményekben való aktívabb részvétel, az emberi jogok érvényesítése mind olyan eszköz a nemzetközi aktorok kezében, amellyel pozitív irányba tudják befolyásolni megítélésüket. A szabadkereskedelem, a gazdasági segélyezés javítja a róluk kialakított képet. Az egyes nemzetközi szereplők a különböző eszközök megfelelő megválasztásával, és az együttműködés révén hatékonyabban tudják megvalósítani céljaikat, ha mások támogatják, de legalábbis nem utasítják el azokat. Ez a nem állami szereplők sajátosságaiból adódóan növelheti azok mozgásterét. Mindezek a képességek és lehetőségek, amelyeket Nossel alternatívaként ajánl, és amelyet smart power-ként

\footnotetext{
34 Suzanne Nossel az Amnesty International USA igazgatója. Korábban a Human Rights Watch munkatársa, illetve az amerikai Külügyminisztérium helyettes államtitkára volt.
} 
foglal össze, lényegében egybeesnek a Nye által használt soft power kifejezés tartalmával.

Nye 2006-ban saját fogalmai alapján definiálja újra a smart power koncepciót. Valójában azt mondja saját korábbi önmagához képest, hogy a hatalom különböző szinteken megjelenő összetevőinek kiegyensúlyozott összetételét tekinti annak. A kényszerítés erejének és a vonzás hatalmának (hard és soft power) megfelelően kiegyensúlyozott kombinációját nevezi smart power-nek. A hangsúlyt továbbra is arra helyezi, hogy a soft power elemekre a korábbinál nagyobb figyelmet kell fordítani. (Nye 2006b)

A hatalmi összetevők felhasználási arányainak megváltoztatása azért került a figyelem középpontjába, mert a világ megváltozásával a nemzetközi kapcsolatok alakulásával az egyes hatalmi típusok hatékonysága, és ezáltal fontossága változott meg. A hidegháború végét követően az Egyesült Államok maradt az egyetlen szuperhatalom. Katonai és gazdasági értelemben is a világ vezető hatalmává vált. 2001. szeptember 11-e, majd az afganisztáni és iraki szerepvállalás nehézségei mégis azt mutatták, hogy pusztán katonai eszközökkel már nem biztosítható egyetlen ország dominanciája sem. A geopolitikai szempontból újjáéledt Oroszország, valamint az elsősorban gazdaságilag, és ennek hozadékaként világpolitikai értelemben is megerősödött, „felnőtté vált” Kína számos térségben képes megakadályozni az unilaterális amerikai törekvéseket. A világgazdaság globalizálódása következtében a nemzeti gazdasági hatalom más-más aspektusai kerülnek előtérbe a különböző tematikus elemzések során. A kommunikációs forradalom mind több nem állami szereplő számára tette lehetővé a nemzetközi folyamatok befolyásolását. Nye analógiájával élve az átalakulóban lévő nemzetközi rendszerben a nagy játszma már egy háromszintes sakktáblán folyik:

- Felső szintje a katonai hatalmi játszma, amelyben elsődlegesen államok vesznek részt. Azonban már ezen a szinten is egyre több új szereplő jelenik meg. Ilyenek a nemzetközi terrorista szervezetek, a magán biztonsági cégek vagy a magánhadseregek.

- Középső szintje a gazdasági kapcsolatok alakulása. Itt az államok, mint elsődleges szabályozók mellett nagyon fontos szerepet játszanak a nemzetközi szervezetek (WTO, EU, NAFTA, stb.), a transznacionális vállalatok és a különböző érdekvédelmi szervezetek, NGO-k.

- Az alsó szinten olyan - elsősorban transznacionális jelenségekhez kötődő hatalmi játszmák zajlanak, mint a nemzetközi terrorizmus elleni küzdelem, a 
klímaváltozás elleni fellépés, a járványok kezelése, a szegénység visszaszorítása, stb. Ezen a szinten az államok és a nem állami szereplők között nagyon sok az interakció, itt elsősorban a soft power eszközök alkalmazása a jellemző. Ez a szint az államok által nehezen kontrollálható.

Ezek a szintek ugyanakkor nem egymástól függetlenül léteznek, nem külön-külön kezelendők. Összefüggnek egymással, erősítik, vagy épp kioltják egymást. Mint fentebb láttuk, a gazdasági hatalom szorosan összefügg a vonzás hatalmával - bár ezt mindaddig nem szoktuk felismerni, amíg erősítik egymást, csak akkor, amikor gyengítik. A katonai hatalom ugyancsak kapcsolatban áll a soft power megnyilvánulásaival. Amint azt a terrorizmus elleni küzdelem kapcsán Rumsfeld amerikai védelmi miniszter kérdésére „Vajon több terroristát fogunk-e el, ölünk-e meg, rettentünk-e el minden nap, mint amennyit a bünözők és radikális vallási vezetők toboroznak, kiképeznek és ellenünk küldenek?” válaszul Nye megfogalmazta, nehéz ezt az egyenletet megoldani olyan stratégia nélkül, ami a szíveket és a tudatot is megnyeri. (Nye 2006a)

A nemzetközi, illetve transznacionális kapcsolatok körének bővülése azt mutatja, hogy egyre több kölcsönhatás zajlik a transznacionális gazdasági és társadalmi kapcsolatok szintjén. A sakktábla két alsó szintje fokozatosan egyre nagyobb jelentőségre tesz szert. A nemzetközi kapcsolatok szereplői a különböző szinteken eltérő mértékben képesek jelen lenni, mivel a hatalmi eszközök közül nem feltétlenül rendelkeznek mindegyikkel, vagy nem tudják a rendelkezésükre álló eszközt megfelelően alkalmazni. Vannak olyan szereplök, amelyek minden hatalmi típussal rendelkeznek, és azok kombinációját használják: ilyenek az államok, de egyre nagyobb mértékben a nemzetközi terrorista szervezetek is. Az államok esetében tehát a smart power egyenlő magával a hatalommal, és esetükben sokkal helyesebb lenne ,a hatalmi összetevők okos kombinációjáról” beszélni. A legtöbb nem állami szereplö ugyanakkor nem rendelkezik a különböző hatalmi összetevők teljes vertikumával. Az ő esetükben a kérdés inkább úgy merül fel, hogy a rendelkezésre álló eszközöket hogyan tudják a legnagyobb hatékonysággal érdekeik érvényesítésére felhasználni.

\subsection{Alkalmazkodási kényszer}

A körülmények változása alkalmazkodást követel meg az nemzetközi szereplőktől legyenek azok államok, nemzetközi szervezetek vagy nem állami szereplők. Az új 
szereplők megjelenésére, illetve a régi szereplők befolyásának növekedésére meg kell találni az adekvát válaszokat, amelyek közül az egyik lehet a hatalmi-mixen belüli változtatás, új eszközök alkalmazása vagy feledésbe merült, háttérbe szorult eszközök előtérbe helyezése.

A bipoláris világ katonai szembenállásának megszűnésével, a határokon átnyúló kihívások megjelenésével, a világgazdaság globalizálódásával, a transznacionális vállalatok befolyásának növekedésével és a kommunikációs forradalom következtében az államok új típusú kihívásokkal kerülnek szembe. A hard és a soft power elemeinek fontossága a fent leírtak szerint változik meg az új kihívók és kihívások tükrében. Ez közvetett módon azt is jelenti, hogy az országok relatív befolyásolási képessége anélkül változik meg, hogy az érdekérvényesítési eszközei megváltoznának. Amennyiben elfogadjuk az előző pontban megfogalmazott tételt, hogy a 21. században a soft power eszközök által befolyásolható kérdések jelentősége megnő, akkor logikusan következik, hogy azok a szereplők, amelyek relatíve kisebb hard power eszközökkel rendelkeznek, és korábban ennek következtében kisebb befolyással rendelkeztek, a jövőben - relatív értelemben nagyobb vonzási képességüknél fogva - nagyobb lehetőséget kapnak érdekeik érvényesítésére. Ilyen a nem állami szereplők többsége.

A globalizáció eredményeként a gazdasági kapcsolatok lényegesen átalakulnak, változásuk dinamikája folyamatosan nő. Az információ áramlás felgyorsulásával az egyes nemzeti piacokról kialakuló kép meghatározó a nem állami gazdasági partnerek számára. A gazdasági szankciók és a támogatások mellett egyre növekvő jelentőségre tesz szert a gazdasági környezet vonzó jellege, kiszámíthatósága, a kedvező befektetési környezet. Ezek a paraméterek már elsősorban soft power eszközök, amelyek alakítása időigényes, központilag nehezen kontrollálható, ugyanakkor kevésbé tőkeigényes lehetőség. Szükségessé teszi egyrészt a gazdasági szereplőkkel történő folyamatos egyeztetést, véleményük, igényeik meghallgatását, másrészt a világgazdaság apró változásainak állandó nyomon követését. Wilson azt hangsúlyozza, hogy a kényszerítő erőt és a vonzás hatalmát úgy kell kombinálni, hogy azok ne csak kiegészítsék egymást, de kölcsönösen erösítsék is egymás hatását. (Wilson 2008) A smart power ebben a felfogásban több mint a soft és hard power egyszerü matematikai összege.

A transznacionális kapcsolatok szintjén megjelenő interakciók jelentőségének növekedése a globalizált nemzetközi rendszerben egyben azt is jelenti, hogy azok a szereplök, amelyek ezen a szinten nagyobb vagy növekvő befolyásra képesek szert tenni, a nemzetközi kapcsolatok összességén belül is növekvő befolyással bírnak. A 
gazdasági erőviszonyok változása, a kommunikációs forradalom, valamint az állami és nem állami gazdasági szereplök azzal járó reagáló képességének változása mind több nem állami szereplő számára teszi lehetővé a nemzetközi folyamatok befolyásolását ezen a szinten. A smart power fent elemzett összetevői jelentőségének különböző mértékű egymáshoz viszonyított alakulása a nem állami szereplőket erősíti relatív értelemben, mivel megnő azoknak a hatalom részeknek a jelentősége, amelyekkel a nem állami szereplök is rendelkeznek - azoknak a kárára, amelyek az államok monopóliumát képezik. Ezt tovább erősíti az a tendencia is, hogy bizonyos korábban állami monopóliumnak tekintett hatalom összetevők megjelennek a nem állami szereplök eszköztárában is. 


\section{FEJEZET}

\section{A NEM ÁLLAMI SZEREPLŐK MEGNÖVEKEDETT BEFOLYÁSÁNAK RENDSZER SZINTÜ OKAI}

Az elemzések többsége ma még az államok által meghatározott keretekben, az államok által irányított nemzetközi kapcsolatok rendszerének feltételezéséből indul ki. A globalizáció és az internalizáció párhuzamos folyamatai azonban olyan lehetőségeket teremtettek, amelyek megnyitották az utat a szubnacionális aktorok nemzetközi megjelenése, szerveződése és hatékony érdekérvényesítése előtt. Az állami határokon átnyúló globális kihívások, akárcsak az államok által saját határaikon belül el nem látott funkciók, megteremtették az érvényesülés lehetőségét a nem állami szereplők előtt. A nemzetközi folyamatok alakulását szemlélve ezért mind gyakrabban merül fel a kérdés, hogy milyen mértékben képesek azokat befolyásolni a nem állami szereplők. Számuk növekszik, és mind több területen tesznek szert a döntéshozatali folyamatok alakításának képességére. Hatalmuk, amint azt az előző fejezetben láttuk, esetenként abszolút, esetenként relatív értelemben nő.

A nem állami szereplők államokhoz való viszonya igen sokrétü. Egyrészt lehet helyettesítö, amikor az államok helyett, vagy azokkal versenyezve lépnek fel. A szociális ellátórendszerek párhuzamos kialakítása, vagy akár a helyi közösségekben a rendfenntartó funkciók gyakorlása létezhet az állam tevőleges vagy hallgatólagos jóváhagyásával, de akár az állam akarata ellenére is. Más esetekben az országok olyan kihívásokkal néznek szembe, amelyek országhatárokon vagy akár kontinenseken átnyúló gazdasági, illetve környezeti problémákból adódnak. Ezeket az államok különkülön nem, csak együttmüködve lennének képesek megoldani. Példaként említhetjük a globális felmelegedést, vagy a nemzetközi szervezett bünözést.

Másrészt a viszony lehet kiegészítő, amikor a szereplők közösen vagy egymást erősítve végeznek valamilyen tevékenységet. A demokratikus értékek terjesztése olyan tevékenység, amelyet sok esetben a nem állami szereplök hatékonyabban tudnak megvalósítani. A demokrácia, az emberi jogok és a tolerancia értékeinek elfogadtatása egy adott társadalomban nemritkán az ország belügyeibe való beavatkozás és a külső segítség határán mozog, így más államok számára érzékeny, fel nem vállalható tevékenység. Esetenként az állami és a nem állami szereplők együttes fellépése jelenti a 
megoldást, ahol mindkét fél saját eszközeivel és képességeivel járul hozzá a közös cselekvéshez. Gyakori az együttmüködés az egyes problémák tematizálása, a megoldási lehetőségek párhuzamos felkutatása során. Ilyen lehet a civil kontroll kialakítása, ahol az állam megteremti a kereteket, amelyeket a nem állami szereplök töltenek meg tartalommal. Mind több esetben kerül sor arra is, hogy az állami szervek meghatározott formában partnerként vonják be a döntéshozatalba ezeket a szervezeteket, vagy legalábbis elfogadják azok szakmai hozzájárulását.

Harmadrészt meg kell említeni azokat az eseteket is, amikor ellentétes érdekek ütközéséről beszélhetünk. A konfliktus az államok és a nem állami szereplők között rendeződhet békés vagy erőszakos módon. Egyes szereplők az államok (vagy bizonyos esetekben a nemzetközi illetve kormányközi szervezetek) tevékenységével szembeni ellenérzésüknek, elégedetlenségüknek adnak hangot nyilatkozatok, kampányok vagy akár tömegmegmozdulások formájában. Más szervezetek - a békemozgalmaktól a terrorista szervezetekig - az erőszak alkalmazásától sem riadnak vissza, amennyiben úgy ítélik meg, hogy az céljuk elérésének az egyetlen vagy leghatékonyabb, esetleg csak leglátványosabb módja.

\subsection{Vesztfáliai kudarcok}

Általánosságban megfigyelhető folyamat, hogy a nem állami szereplők kezdetben a „vesztfáliai” államon belül jelennek meg, és az állam által el nem látott, vagy nem megfelelően ellátott funkciók betöltésére törekednek - legyenek azok szigorúan értelmezett állami funkciók vagy államok feletti kihívások -, avagy a nem hatékonyan képviselt érdekek képviseletére szakosodnak. Ezt a folyamatot erősítette a világ különböző térségeiben az 1980-as majd az 1990-es években lezajlott privatizáció. A demokratizálódás útjára lépő államokban ez a jelenség jelenleg is, és a jövőben is megfigyelhető lesz. A privatizáció olyan, korábban az állam hatáskörébe tartozó feladatok elvégzésébe vonja be a nem állami szereplőket, mint a szociális ellátó rendszerek, oktatás, egészségügy és közüzemi szolgáltatások nyújtása. Ezeken felül olyan, az erőszak monopóliumának birtoklását érintő területek magánosításának is tanúi lehetünk, mint a büntetés végrehajtás vagy a magán biztonsági társaságok, amelyek az állammal kötött szerződés alapján, de az állam jogi kötelezettségeit magukon nem viselve végzik tevékenységüket. A 2000-es években egyre több példát találunk erre. (Alston 2005) Ezekről a későbbiekben részletesen szólok. Az állami feladatok magán 
kézbe adása, a magán szféra bővülése definíció szerint növeli a nem állami szereplők mozgásterét, érdekeik megjelenítésének felületét, a rendelkezésükre álló eszközöket és erőforrásokat, valamint ezen keresztül befolyásukat. A belpolitikai problémák külpolitizálódása következtében, a megjelenő globális lehetőségeket kihasználva a nem állami szereplők mind gyakrabban jelennek meg a transznacionális kapcsolatokban. A nemzetközi szintü megjelenésre az esetek többségében hálózatok formájában kerül sor.

A világ több térségében (legnagyobb számban Afrikában) megfigyelhető, hogy a szegényebb országok, és még inkább az úgynevezett bukott államok (failed states) nem képesek ellátni legalapvetőbb funkcióikat sem, úgy mint a rend és a biztonság szavatolása, a szociális és egészségügyi ellátás. Bármennyire is elszomorítóan hangzik, az afrikai országok segélyezési programjainak legnagyobb lebonyolítójaként ismertté vált Oxfam, és a palesztin területeken megkerülhetetlenné vált Hezbollah ugyanazt az ürt tölti be, vagy legalábbis töltötte be eredetileg: a központi kormányzat által nem nyújtott alapvető szociális ellátást voltak hivatottak pótolni. De a Hezbollah nem csak az állami struktúrákkal párhuzamos egészségügyi és oktatási intézményeket működtet, közszolgáltatásokat és szociális ellátást biztosít, valamint alapvető kommunikációs szolgáltatásokat nyújt, hanem a régió államainak akarata ellenére is képes akár fegyveres konfliktust provokálni Izraellel, amint arra 2006-ban is sor került. Hasonlóan Janus-arcú a brazíliai drog-kartellek szerepe - egy pillanatra sem megfeledkezve természetesen azok illegális természetéről és törvényen kívüliségéről. A favellák (nyomornegyedek, elsősorban Brazíliában) urai bizonyos szociális és biztonsági „,alapellátást” nyújtanak, ezzel erősítik lokális társadalmi támogatottságukat, és végső soron saját érdekérvényesítési pozíciójukat nemcsak a favellán belül, de azt kihasználva azon kívül is.

Az államok egymás belügyeibe való beavatkozástól való tartózkodásának kikényszerítése, az államok egymással szembeni bizalmatlansága, illetve a lakosság más kormányokkal szembeni gyanakvása a klasszikusan államközinek tekintett diplomáciai kapcsolatok, és sajnálatos módon a mind gyakrabban szükségessé váló segélyezési politikában ad növekvő szerepet a nem állami szereplőknek. Bár a segélyezési politika szükségszerüségét senki sem vitatja, végrehajtása mind politikailag, mind technikailag gyakran problémát okoz a nemzetközi közösség klasszikus állami szereplőinek. Ezekben a programokban soha nem látott mértékben vesznek részt nem állami szereplők. Mathews (1997) szerint az NGO-k több fejlesztési segélyt osztanak szét, mint az egész ENSZ-család. Gyakran pedig az NGO-k egy-egy részprobléma 
megoldásával járulnak hozzá a nemzetközi erőfeszítések sikeréhez. Így például Darfurban több szervezet is segítséget nyújt naprakész információk gyüjtésével, térképek készítésével a segélyek hatékony célba juttatásához. Ilyenek a GOAL, a Respond, az Oxfam, stb.

Ugyancsak az államhatárokon átnyúló társadalmi kapcsolatok példájának tekinthetők a diplomáciai kapcsolatok különleges - és bizonyos esetekben vitatható - nem állami szereplöi, mint a különböző politikai háttérintézmények, vagy párt alapítványok. Amint azt Dakowska és Tulmets (2007) Németország példáján megállapították, bár a fent említett alapítványok az esetek nagy számában nem felelnek meg a nem állami szereplők egyik definíciójának sem, azokat mégis akként kezelik. Tevékenységi körükbe tartozik részben a civil társadalom megszólítása és bevonása a politikai folyamatokba, részben pedig a nemzetközi kapcsolatok erősítése, kiaknázása. Az 1970es évektől egyre nagyobb szerepet játszanak az állami külpolitika tevékenységének segítésében, az állami szereplök által nehezen megszólítható társadalmi csoportok elérésében, és mind gyakrabban a különböző országok állami és nem állami szereplői közötti párbeszéd, együttmüködés kereteinek kialakításában konferenciák, találkozók megszervezésével. Ezek a „nem állami” események közvetítő szerepet játszhatnak az eltérő álláspontok között, vagy informális kereteket teremthetnek a más formában nehezen megtárgyalható kérdések napirendre tüzéséhez - ezáltal segítve elő a nemzetközi együttmüködést.

\subsection{Hálózatok évszázada}

Élve Slaughter kifejezésével, hálózatos világban élünk. A háború hálózatos: a terroristák és az ellenük harcoló katonaság ereje a mobil harcoló alakulatok, a hírszerzés és a kommunikáció hálózatainak sikerétől függ. Szemben a történelmi tapasztalatokkal ma már nem a lakosság és a terület nagysága a meghatározó, nem a frontra vezényelhető haderő nagysága vagy az elfoglalni, illetve megvédeni szándékozott terület mérete dönti el a hatalmi viszonyokat. A hidegháború vége óta mind jobban elharapódzó aszimmetrikus konfliktusok más törvények alapján müködnek.

A diplomácia hálózatos: a nemzetközi problémák megoldása az állami és a civil szereplők hálózatainak együttmüködési képességét igényli. Csak az a nemzetközi szereplő lehet sikeres, aki része a megfelelő hálózatoknak. A hálózaton belüli pozíció pedig nagyban meghatározza az adott szereplő lehetőségeit. 
Az üzleti világ hálózatos: a management könyvek mind a vertikális irányítástól a horizontális hálózatok müködtetése felé való elmozdulásra tanítanak. Már a multinacionális vállalati modellt is kikezdeni látszik a központi irányítás helyett a rendszer-integrációra épülő, sok helyi egység hálózataként leírható „globálisan integrált vállalat”. Ezt erősíti a kereskedelem és a tőkepiac liberalizációja, a külföldi tőkebefektetések növekedése. Ezek a gyakran „globalizáció”-vá egyszerüsített folyamatok - liberalizáció, dereguláció és befektetés-ösztönzés - az iparosodott államok hathatós közremüködésével indultak, de ma már sokkal inkább megfelelnek a nem állami szereplők érdekeinek.

A civil társadalom is hálózatos (lásd 2. ábra). A globális politikai és társadalmi változások a 21. századra a transznacionális szereplők tízezreit, hálózataiknak ezreit hozták létre. Míg az 1990-es évekig a nemzetközi közösségen belüli civil tevékenységet (a korábban tárgyalt gazdasági szférát ide nem értve) könnyüszerrel lehetett az NGO-k tevékenységével azonosítani (Alston 2005, p.18), addig ma már a nem állami szereplők széles köre vesz aktívan részt a transznacionális hálózatok alakításában és müködtetésében. Tevékenységük túlmutat a hagyományos érdekképviseleten, és a rendelkezésükre álló erőforrások átlépik a figyelmen kívül hagyhatóság határát.

2. számú ábra: A társadalmi hálózatok globális térképe 2011-ben

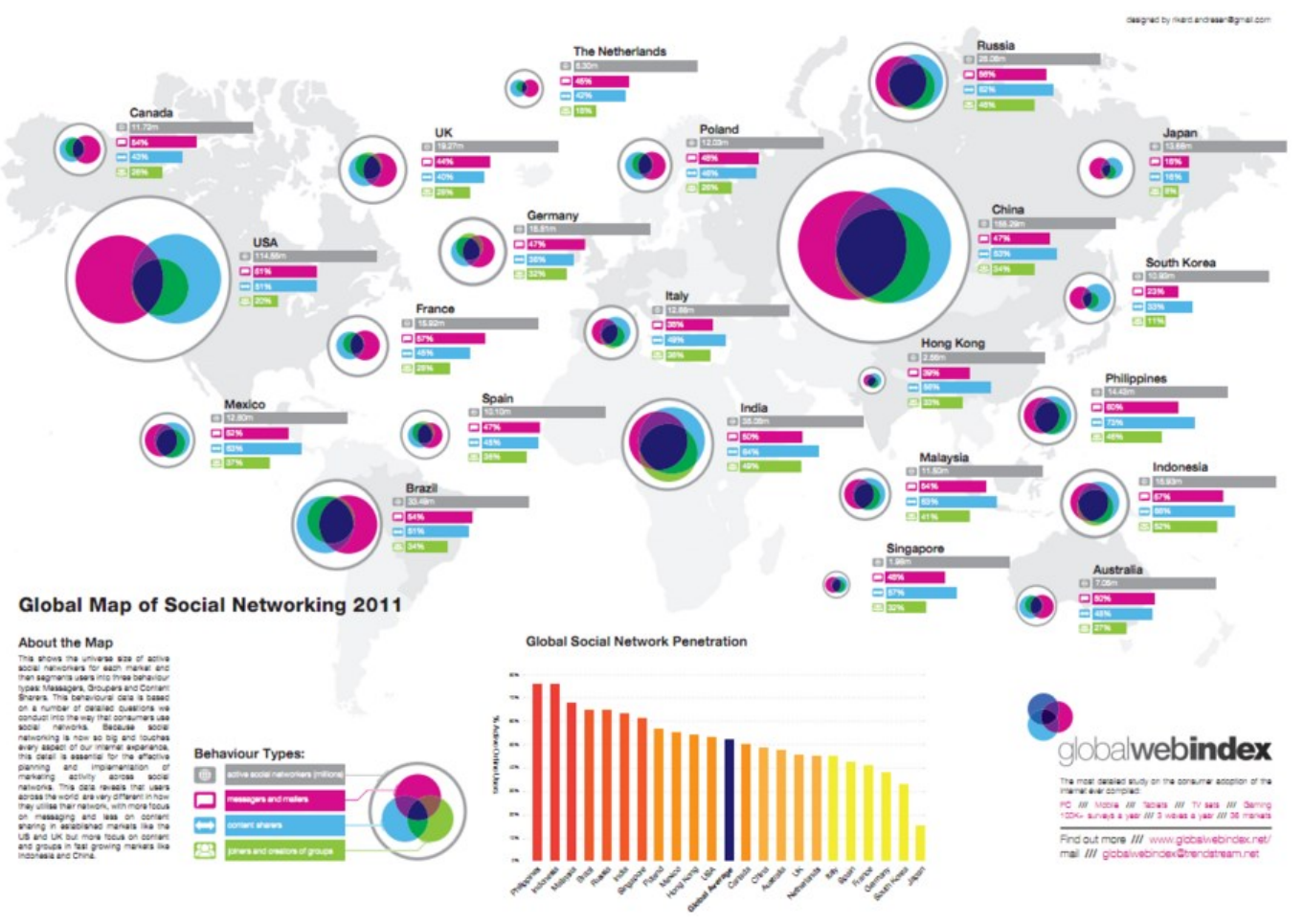

Forrás: globalwebindex 
A média is hálózatos: a blogok és más interaktív kommunikációs eszközök sokszereplős, többirányú kommunikációt tesznek lehetővé. Fentebb említettem a média növekvő szerepét a nemzetközi kapcsolatok tematizálásában. A 21. század ugyanakkor a telekommunikáció fejlődése, és azon belül is az internet elterjedése révén megnyitotta az utat a hagyományos média mellett a kommunikációs hálózatok világának robbanásszerü növekedése elött. Az internet alapú „társadalmi média” (social media) a különböző szereplök között kialakított hálózatok, valamint a hálózatok között kialakult kapcsolatok rendszerére épül, és a világ bizonyos térségeiben a hagyományos médiánál jelentősebb penetrációval rendelkezik.

A hálózat, mint a nemzetközi rendszer „szereplője” természetesen nem új jelenség. Még az egyház is - meglévő hierarchiája ellenére - napi működése és kapcsolattartása szempontjából hálózatos, ha a földet behálózó milliónyi templom és közösség kapcsolataira gondolunk. (Slaughter 2009)

A nem állami szereplők szempontjából a szociális hálózatok kialakulásának fontos hozadéka van: úgy válnak a kommunikáció költségei minimálissá, hogy az üzenet a bármely kérdésben kialakított virtuális közösségen keresztül nagyon nagy számú, a téma iránt érdeklődő befogadóhoz nagyon rövid idő alatt képes eljutni. A Facebook, a Twitter, a Facekoo vagy a Renren alkalmas eszköz lehet arra, hogy három lépésben, gyakorlatilag valós időben, több tíz millió felhasználóhoz jusson el egy adott információ (lásd 3. ábra).

3. számú ábra: A Facebook felhasználók számának növekedése, 2004-2011

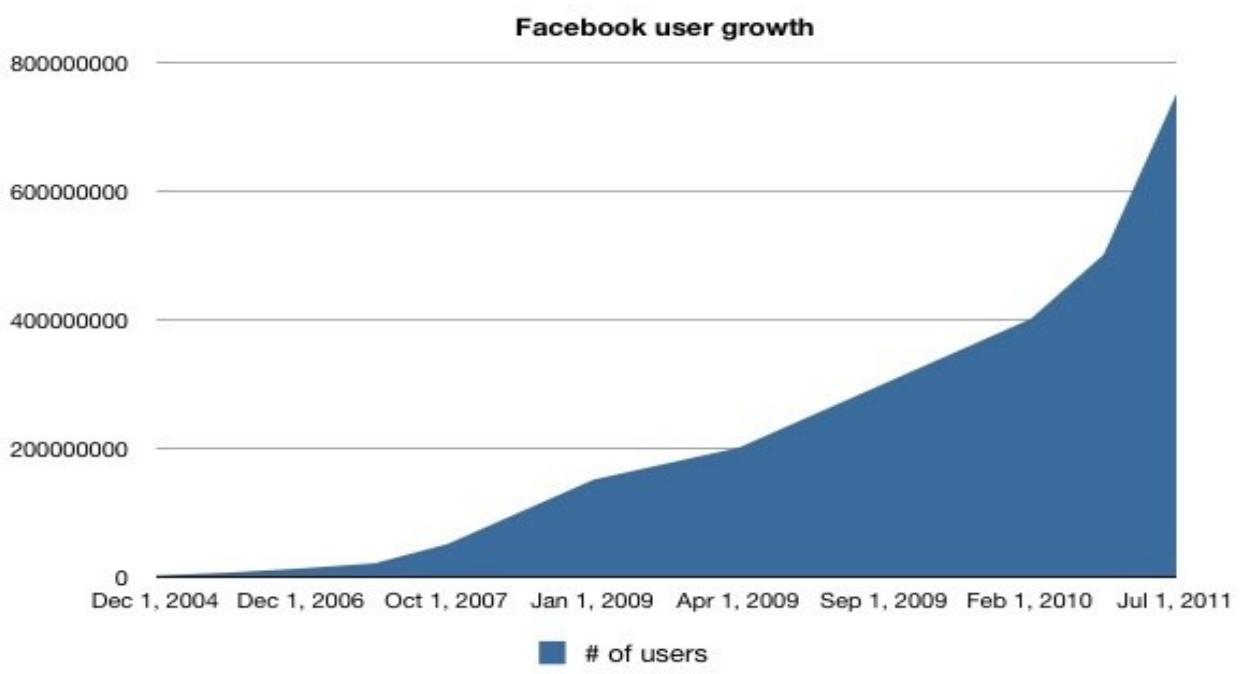

Forrás: Tecca 
Természetesen egy virtuális tematikus közösség nem minden esetben rendelkezik azokkal az attribútumokkal, amelyek azután ahhoz lennének szükségesek, hogy az állami szereplök döntéseit, nemzetközi lépéseit hatékonyan képesek legyenek befolyásolni, de óriási potenciális lehetőséget rejtenek a nem állami szereplők érdekérvényesítési képességének fejlesztésére.

A 21. században ezek a hálózatok egyszerre léteznek az állami szint alatti és feletti transznacionális, valamint az államok közötti nemzetközi térben. Slaughter (2009) szerint az államok lassabban ébredtek rá az alkalmazkodás szükségességére, mint a nem állami szereplők, és csak fokozatosan képesek hozzáidomulni az új rendszerekhez. A nem állami szereplök lépéselőnye mindenképpen növeli a befolyásukat, a kérdés csak az, hogy azt milyen mértékben lesznek képesek kamatoztatni.

\section{3. Új kihívások}

A nemzetközi kapcsolatok rendszere párhuzamosan bővül és globalizálódik. A korábban az államhatárokon belül kezelt kérdések nemzetközi kontextusba kerülnek, a nem állami szereplők közül egyre többen nemzetközi, de legalábbis transznacionális szinten igyekeznek érvényesíteni érdekeiket. A piacok globalizálódása, a termelés és az értékesítés határokat nem ismerő szervezése, a multinacionális, transznacionális, illetve globálisan integrált vállalatok megjelenése és megerősödése a gazdasági kérdések nemzetközi szintű kezelését tette szükségessé. A külföldi tőkebefektetések, a nyitott nemzetközi pénzpiacok mind a gazdasági szereplők, mind az azok müködését szabályozó nemzeti vagy nemzetközi hatóságok számára szükségessé tették a nemzetközi szintü együttmüködést.

Más esetekben az országok olyan kihívásokkal néznek szembe, amelyek országhatárokon vagy akár kontinenseken átnyúló gazdasági, illetve környezeti problémákból adódnak. A globális felmelegedés, az óceánok szennyezése csak az érintett szereplők számában különböznek egy határfolyó szennyezésétől vagy a határon átterjedő légköri szennyezés kétoldalú problémájától. Ezeket az egyes nemzeti szereplők külön-külön nem, csak együttmüködve képesek megoldani. További példaként említhetjük a nemzetközi migrációt, a nukleáris non-proliferációt, vagy a nemzetközi szervezett bünözéselleni küzdelmet.

Ugyancsak fontos morális kötelesség az univerzálisnak tekintett értékek terjesztése és a nemzetközi kötelezettségvállalások betartásának ellenőrzése és elősegítése. Az emberi 
jogok és a demokratikus értékek támogatása, a nők és a gyermekek jogainak védelme a nemzeti kereteken túllépve transznacionális, illetve esetenként globális kérdéssé vált. Bacevich találóan mutat rá, hogy a legfőbb megoldandó problémákká - legalábbis a transzatlanti térségben - a globális kérdések váltak. Az elnökválasztási kampány témáiról, mint értelemszerüen a választók számára legfontosabbnak tekintett kérdésekről azt írja, hogy míg korábban az elnöki pozícióra aspiráló jelöltek megélhetést ígértek mindenkinek, ma a jelöltek a terrorizmus, a nukleáris fegyverek, a klímaváltozás, a szegénység és a járványok leküzdését ígérik. (Bacevich 2008)

Megváltozott a nemzetközi közösséget foglalkoztató konfliktusok jellege is. Korábban a tömbök közötti szembenállás korszakában a végső elrettentést sem kizáró (nukleáris) globális konfliktus nem teremtett lehetőséget a nem állami szereplők érdemi hozzájárulására. A hidegháborút követően a lokális konfliktusok kerültek az előtérbe, és az általuk dominált nemzetközi színpad jelentősebb szerep betöltésére adott alkalmat a nem állami szereplőknek. 1990 óta a fegyveres konfliktusokat az államok és nem állami szereplők közötti összeütközések dominálják. A technológiai fejlődés következtében jelentős mértékben megnőtt az egyre nagyobb számú fegyveres nem állami szereplő pusztítási képessége. (Nye 2011) Esetenként azonban ezek a konfliktusok épp ellenkezőleg pozitív tartalmú beavatkozást igényeltek a nem állami szereplők részéről. Az emberi jogok érvényre juttatása, a helyi közösségek jogainak és esetenként létének védelme, a kisebb intenzitású helyi konfliktusokban a segélyek célba juttatása, a közvetítés, a helyzetértékelés a nem állami szereplőknek testhez álló feladatok.

A megoldandó problémák nemzetköziesedése az azokra adandó válaszok nemzetköziesedését teszi szükségessé, akár transznacionális együttmüködés révén, akár regionális vagy globális nemzetközi hálózatok, illetve szervezetek formájában.

\subsection{A nem állami szereplők relatív hatalmának növekedése}

A nemzetközi kapcsolatok egyik, ha nem a legfontosabb fogalma a hatalom, a szereplök képessége arra, hogy érdekeiknek érvényt szerezzenek. Fentebb megvizsgáltam, hogy hogyan változik a hatalom a 21. század várható fejleményei tükrében. Most arra keresem a választ, hogy a nem állami szereplők céljaik elérése érdekében végzett cselekedeteik során milyen hatalommal rendelkeznek abszolút vagy relatív értelemben a nemzetközi rendszer többi aktorával szemben. 
Minden nemzetközi szereplő, akár államokról, akár nem állami szereplőkről beszélünk, különböző módokon és eltérö mértékben képes érdekeinek érvényt szerezni. A nemzetközi érdekérvényesítési képesség beazonosításához meg kell vizsgálni egyfelől azt, hogy az egyes aktorok a hatalom milyen fent részletezett eszközeivel, összetevőivel rendelkeznek, másfelöl, hogy azokat az eszközöket milyen keretek között tudják alkalmazni.

Amint a harmadik fejezetben láthattuk, a hatalom különböző összetevőinek szétválasztása - katonai, politikai, gazdasági, diplomáciai, kulturális, stb. - nem új jelenség. Minden nem állami szereplőnek ezekből tevődik össze a hatalma, azaz befolyásolási képessége, még akkor is, ha a hatalom bizonyos elemei nulla értékủek.

A hatalmi összetevők felhasználási arányainak megváltoztatása azért jelenthet nagyobb érdekérvényesítési lehetőséget a nem állami szereplőknek, mert a világ megváltozásával a nemzetközi kapcsolatok alakulásával az egyes hatalmi típusok hatékonysága, és ezáltal fontossága változott meg.

A nemzetközi kapcsolatok szereplöi a Nye által definiált különböző hatalmi szinteken eltérő mértékben képesek jelen lenni, mivel a hatalmi eszközök közül nem feltétlenül rendelkeznek mindegyikkel, vagy nem tudják a rendelkezésükre álló eszközt megfelelően alkalmazni. A nem állami szereplők - a terrorista és szeparatista csoportokat leszámítva - nem rendelkeznek jelentős katonai hatalommal. Azok elsősorban a hatalmi mix gazdasági és soft power elemeit alkalmazzák. Amennyiben elfogadjuk a hatalom változásáról korábban leírtakat, akkor logikusan következik, hogy a nem állami szereplők, amelyek relatív értelemben nagyobb mértékben rendelkeznek a vonzás hatalmával, a jövőben nagyobb lehetőséget kapnak érdekeik érvényesítésére. Ráadásul, a soft power növelése nem is annyira tökeigényes. A vonzás hatalma az átalakuló világgazdaságban, a kereskedelmi kapcsolatok javításáért és a közvetlen tőkebefektetésekért folyó küzdelemben ugyancsak nagy szerepet kap. A globalizáció eredményeként a gazdasági kapcsolatok lényegesen átalakulnak, a nem állami gazdasági szereplők lényeges befolyásoló tényezővé, illetve meghatározó partnerré lépnek elö.

A soft power intézményi és politikai feltételeinek megteremtése természetesen komoly kihívás a jelenlegi helyzetben, ami legfőképp a nemzetközi rendszer hosszú távú strukturális átalakulásának a következménye. Ez a nemzetközi kapcsolatok szinte minden résztvevője számára következményekkel jár: az állami szereplőkkel szemben elsősorban kihívást jelent, a nem állami szereplők számára pedig bővülő lehetőségeket. 
Gelb - elfogadva a hatalom hármas összetevőit - arra hívja fel a figyelmet, hogy a hatalom hatékony érvényesítéséhez öt szempontot kell szem előtt tartani:

- biztosítani kell a gazdasági stabilitást és dinamizmust, mert az szolgál a nemzetközi cselekvés alapjául;

- építeni kell a szereplök között fennálló kölcsönös nélkülözhetetlenségre a 21 . században;

- a kezelendő veszélyek között egyértelmü prioritást kell felállítani, ami különbözhet a korábbiaktól;

- jelentősebb mértékben kell élni a megelőzés eszközével, hogy elkerülhetőek legyenek a háborúk;

- alkalmazkodni kell a hatalom változó jellegéhez, a hatalom összetevői fontosságának módosulásához. (Gelb 2009)

Bíró felhívja a figyelmet arra is, hogy a hatalom nemcsak időben, hanem térben is feltételes és ideiglenes. Azok a szereplők, akik egy adott területen meghatározónak tekinthetőek, más területeken, akár ugyanazon időintervallumon belül, nem biztos, hogy tudják érvényesíteni akaratukat. (Bíró 1998)

A fentieket figyelembe véve összességében megállapítom, hogy a vesztfáliai kudarcok, valamint a 21. században várhatóan meghatározóvá váló új kihívások a nem állami szereplők befolyásának növekedését vonják maguk után. A hatalmi mixben a vonzás hatalma erejének relatív növekedése, valamint a hálózatosodás a nem állami szereplőknek kedvez. Nem mondhatom ugyanakkor azt, hogy a nem állami szereplők hatalma összességében, minden hatalmi típust figyelembe véve dominánssá válna, de a hatalom összetevőinek relatív változása - mint fentebb részletesen ismertettem - a nem állami szereplők befolyásolási képességének relatív növekedéséhez vezet. 


\section{FEJEZET \\ A NEM ÁLLAMI SZEREPLŐK ÉRDEKÉRVÉNYESÍTÉSÉNEK FORMÁI - AZ INTERAKCIÓK SZINTJEI}

A nem állami szereplők érdekérvényesítési tevékenysége - némi leegyszerüsítéssel - a transznacionális kapcsolatok szereplőinek három jól elkülöníthető csoportjára irányul: az államok, a nemzetközi szervezetek vagy más nem állami szereplők (jellemzően gazdasági társaságok). A befolyásolás lehet közvetlen vagy közvetett.

Fontos különbséget tenni a transznacionális kapcsolatok vizsgálata során azok közvetett befolyásolása és azok közvetlen alakítása között. Míg az érdekérvényesítés csak közvetett beleszólást enged a folyamatok alakításába az azokat meghatározó szereplők viselkedésének befolyásolása révén, a transznacionális események és folyamatok közvetlen alakításának képessége új lehetőséget hordoz magában. A 21. században a nem-állami szereplők mozgásterének változásában a minőségi ugrást épp ez a sajátosság, a befolyásoláson túlmutató közvetlen alakítási képesség kialakulása jelenti.

\subsection{Az államok szintjén}

A nem állami szereplők érdekérvényesítésének szükséges ám nem elégséges feltétele az állami döntéshozatal megfelelő szerveivel való kapcsolat kialakítása. ${ }^{35}$ Ez elsősorban az államberendezkedéstől, az intézményi szerkezettől és a belpolitikai nyitottságtól függ. A nem állami szereplőktől a hozzáférés kialakításának képessége elsősorban az intézményi viszonyok megfelelő felmérését igényli: más csatornák alkalmazását esetleg kiépítését - teszi szükségessé egy központosított politikai, államigazgatási rendszer, mint egy transzparens, nyitott közigazgatás, avagy szélsőséges esetben a központi kormányzat teljes hiánya, az államigazgatás szervezetlensége.

Érdemes és fontos hangsúlyozni a nem állami szereplők befolyásolási lehetőségeinek és vonatkozó korlátainak különbözőségeit a különböző államokkal szemben, amit a 4. ábra foglal össze. A fejlődő világban a gyakran gyenge központi hatalommal bíró államok esetenként bukott államok - jelentős teret engednek a transznacionális szereplőknek,

\footnotetext{
${ }^{35}$ Itt alapvetően a döntés előkészítők és a döntéshozók körére gondolunk, de nem kívánunk belemenni a közpolitikai, döntéshozatali eljárások részleteibe.
} 
vallási mozgalmaknak, menekülteket segítő szervezeteknek, illetve helyi befolyással bíró erőszakszervezeteknek. Utaltam korábban a transznacionális vállalatok társadalomszervező szerepére, a Hezbollah határokon átnyúló aktivitására, a favellák helyi befolyására, stb. Az Al-Jazeera létrehozása, valamint a Muszlim Testvériség politikai térben való megjelenése rávilágít ugyanakkor például az arab országok másik jellegzetességére is. A civil társadalom ezekben az országokban az elmúlt évtizedekben indult érzékelhető fejlődésnek. A nem kormányzati szektor bővülése azonban nem járt együtt - legalábbis egyelöre - érdekérvényesítési képességének növekedésével. A nem állami szereplők gyakran hamarabb válnak képessé érdekeik megjelenítésére a transznacionális erőtérben, mint saját államukban. Ezen szereplők figyelembe vétele nélkül azonban a társadalmi, politikai és gazdasági folyamatok nem értelmezhetők, ezért vizsgálatuk megkerülhetetlen - tudva azt, hogy számuk és érdekérvényesítési képességük más térségekkel való összehasonlításban jelenleg még alacsony.

Más az állami struktúrák és a nem állami szereplők viszonya a fejlett, jól kiépült államigazgatással rendelkező országok esetében. Ennek megfelelően itt más az érdekérvényesítés lehetősége - legyen szó a folyamatok befolyásolásáról vagy azok közvetlen alakításáról. Az államok elősegíthetik vagy épp ellenkezőleg akadályozhatják a belföldi vagy nemzetközi nem állami szereplök megjelenését és tevékenységét az országban. Ezen szereplők száma a fejlett országokban nemzetközi összehasonlításban magas, tevékenységi körük igen kiterjedt, a rájuk vonatkozó szabályozás előrehaladott.

A transznacionális kapcsolatok körének folyamatos bővülésével, a kommunikációs csatornák nehezebb ellenőrizhetőségével a nem állami szereplők előtt további lehetőségek nyílnak meg.

Huntington (1973) a nem állami szereplők aktivitásának korai vizsgálatakor még a megnyíló lehetőségek korlátait hangsúlyozta. Gyakori, hogy a transznacionális szereplők csak abban az esetben tudják tevékenységüket folytatni, ha megállapodásra jutnak azokkal az államokkal, amelyek szuverenitást gyakorolnak müködési területük felett. A megállapodás tartalmazza a müködés feltételeit, amelyek elfogadása és betartása teszi lehetővé a nem állami szereplők számára tevékenységük folytatását. Ugyanakkor már külön foglalkozik azzal a kérdéssel, hogy mennyiben lehet választása az államnak. Bizonyos esetekben ugyanis a nem állami szereplők olyan erős tárgyalási pozícióba kerülhetnek, ami nem csak a megállapodás létrejöttét garantálja, de akár még a feltételek meghatározását, kedvezőbb feltételek biztosítását is lehetővé teheti. Ennek klasszikus példái a gazdasági, befektetési megállapodások, vagy az adott ország 
számára fontos iparágban felhalmozott know-how bevitele. Huntington szerint a megállapodás három fő tényezőt tükröz: a két fél számára származó előnyöket; a felek tárgyalóerejét; a felek számára nyitva álló más lehetőségeket.

4. ábra: A transznacionális nem állami szereplők hatása a döntéshozatalra az állami struktúrák függvényében

\begin{tabular}{|l|l|l|}
\hline Belső müködési struktúra & $\begin{array}{l}\text { Hozzáférés az } \\
\text { intézményekhez }\end{array}$ & $\begin{array}{l}\text { Hatás a döntéshozatalra } \\
\text { hozzáférés esetén }\end{array}$ \\
\hline Államilag ellenőrzött & Legnehezebb & $\begin{array}{l}\text { Jelentős, ha az állami } \\
\text { szereplö együttmüködése } \\
\text { elérhető }\end{array}$ \\
\hline Állam által dominált & Nehéz & $\begin{array}{l}\text { Jelentős, ha az állami } \\
\text { szereplö együttmüködése } \\
\text { elérhető }\end{array}$ \\
\hline Átmeneti & Nem túl nehéz & Nem valószínü \\
\hline Korporatív/tárgyalásos & Nem túl könnyü & $\begin{array}{l}\text { Jelentős és tartós, ha erős } \\
\text { társadalmi vagy politikai } \\
\text { szövetségessel történik }\end{array}$ \\
\hline Társadalom által dominált & Könnyü & Nehéz koalíció-építés \\
\hline Töredezett & Legkönnyebb & Valószínütlen a hatás \\
\hline
\end{tabular}

Forrás: Risse-Kappen 1995, p. 28

A nem állami szereplők és az állam kapcsolata összetett kétirányú kölcsönhatás, ami alapvetően három jól elkülöníthető szintre bontható:

1. Talán a leghagyományosabb tevékenység a nemzeti szabályozások alakítása, egy-egy ország belső szabályozásainak befolyásolására való törekvés. A nem állami szereplők itt saját szektoruk vagy érdeklődési területük kérdéseinek szabályozását igyekeznek számukra kedvező irányba mozdítani: a vállalati szféra a gazdasági szabályozást, a fogyasztóvédelemben aktív NGO-k a fogyasztóvédelmi kérdésekkel kapcsolatos magatartást, a környezetvédők a környezetvédelmi törvényt, és hasonlók. Ennek sajátos formája, amikor jellemzően a közvetlen tőkebefektetésekért folyó küzdelem során - a gazdasági társaságok vagy érdekképviseletek olyan belső szabályozás-módosításra bírják rá az adott kormányzatot, ami valamely másik ország szabályozásához képest 
jelent kedvezőbb feltételeket, szabályozási vagy éppen liberalizálási versenybe kényszerítve ezáltal az állami szereplőket. Itt fontos utalni arra a visszásságra, hogy a nem kormányzati szereplök egyre nagyobb részvétele ellenére (legyen szó egy probléma tematizálásáról vagy konkrét egyezmény szövegezéséről) a végeredményként megszülető nemzeti szabályozás, illetve nemzetközi egyezmények továbbra is csak az adott államra, vagy az egyezményben részes államokra vonatkoznak. Azok végrehajtása vagy végrehajtatása a megfelelő állami szereplők feladata. A nem állami szereplők valójában kockázatvállalás nélkül vesznek részt a folyamatban, mivel semmilyen értelemben sem vonhatók felelősségre. Egyes próbálkozások az államokon keresztül javasolnák a nem állami szereplők felelősségre vonásának biztosítását. Mások a nemzetközi bíróságok joghatóságát terjesztenék ki, mivel jelenleg például az ICC nem rendelkezik joghatósággal jogi személyiségek felett. Ez a kérdés a nem állami szereplők tevékenységének szabályozása szempontjából kiemelkedően fontos.

2. Másik tevékenység az államok közötti tárgyalások tematizálása, illetve befolyásolása. A nemzetközi nem állami szereplök egyre nagyobb mértékben képesek arra, hogy meghatározzák azokat a témákat, amelyeket az államok nemzetközi tárgyalásaik során nem hagyhatnak figyelmen kívül. Ebben elsősorban a média multiplikátor szerepére támaszkodhatnak, illetve arra építhetnek, hogy a gyakran zárt ajtók mögött zajló tárgyalásokkal szemben a közvélemény nyitottabb, fogékonyabb a médiában megjelenő témákra. Ebben az esetben különbséget kell tenni a média mint multiplikátor és a média mint nem állami szereplö között. Az elöbbi esetben az állami és a nem állami média is szerephez jut - bár különböző mértékben. Az utóbbi esetben ki kell zárni a vizsgálatból az állami csatornákat, és csak a nem állami finanszírozású médiát tekinthetjük értelemszerüen nem állami szereplőnek. A befolyásolás hatékonyságának igazán lényeges szintje az (lenne), ha a nem állami szereplők a tematizáláson túl az érdemi tárgyalásokba, a döntések meghozatalába is képesek bekapcsolódni. Ez ma még csak kevés esetben valósul meg, de a felhalmozott tudás, illetve a végrehajtás során vállalt aktív és bizonyos esetekben megkerülhetetlen szerep miatt a jövőben várhatóan növekvő jelentőségre tesz szert.

3. További tevékenység a korábban említett erőszakos eszközökkel történő fellépés, amelynek célja az állam funkcióinak és képességeinek csorbítása, 
bizonyos esetekben egyes állami funkciók átvétele, vagy extrém esetben magának az állam létének a megkérdőjelezése. Több szerző ezt kritikaként fogalmazza meg: tevékenységük célja lehet negatív, rosszindulatú is. Ezt a kritikát akkor érthetjük meg, ha visszagondolunk a nem állami szereplök vizsgálatának történelmi vonatkozásaira. Azok a szerzők, akik ezt a mozzanatot negatívumként tüntetik fel, abból a romantikus elképzelésből indultak ki, ami a múlt század második felében jellemezte a nem állami szereplők (elősorban az NGO-k) megítélését. Reinisch (2005) megállapítja, hogy az elmúlt évtizedekben lényegesen megváltozott az a helyzet, hogy a nem állami szereplők a ,jó fiúk”, míg az államok a „rosszak”, és a különböző nem állami szereplők tevékenysége egyre gyakrabban képezi bírálat tárgyát. Halliday (2001) találóan fogalmaz, amikor azt írja, hogy fenntarthatatlan jelentőségük állam központú tagadása. A nem állami szereplők, mint erős és megkérdőjelezhetetlenül jó aktorok kritika nélküli támogatásának kora lejárt: ebben az értelemben a 'románcnak' vége.

A hatékony nemzeti szintủ érdekérvényesítéshez szükség van arra is, hogy a nem állami szereplők összességében elegendő befolyással bíró koalíciót hozzanak létre. Ennek kialakítása szinte kizárólag a nem állami szereplőktől függ. A közös fellépésből származó előnyök maximalizálásának lehetősége saját helyzetértékelésük megalapozottságától, valamint stratégia alkotási és együttmüködési képességüktől függ. A befolyásolni kívánt állami szereplő müködésének kellő mélységü ismerete nélkülözhetetlen. A nemzeti és a transznacionális nem állami szereplők egymást kiegészítő képességei és tevékenységi szintjei összeadódnak, de a siker elérésének legfőbb záloga az együttmüködők érdekérvényesítési képessége közötti szinergiák kiaknázása.

Slaughter (2009) rávilágít arra, hogy a magán- és a közszféra állami és civil szereplői tevékenységének összekapcsolódása már nem kizárólag egy irányú folyamat. Összehangolásuk azért szükséges, mivel az államok már nem alakíthatják kizárólagosan a saját szempontjaik szerint a különböző politikákat, ugyanakkor nem is szervezhetik azokat egyszerúen ki nem állami szereplöknek. Az állami szereplöknek egyre növekvő mértékben kell választ adniuk a nem állami szereplők aktivitása jelentette kihívásra. Képesnek kell lenniük a különböző szereplők tevékenységének összehangolására illetve befolyásolására. Az NGO-k nemzetközi tevékenységén keresztül az államközi kapcsolatok tartalma fokozódó mértékben ismertté válik. A közvélemény közvetlen, illetve közvetett alakításának képessége rákényszeríti az állami szereplőket, hogy mind 
több részletbe avassák be az érintetteket. A média nyomása, és ezen keresztül a közvéleménynek való megfelelés lehetősége és egyben kényszere arra ösztönzi az államokat, hogy a zárt ajtók mögött folytatott diplomáciai tevékenységükből egyre nagyobb részt tegyenek ismertté.

Ezt erősíti az a folyamat is, hogy a globalizáció hatására a korábban belügynek számító kérdések közül egyre több nemzetköziesedik, egyre nagyobb mértékben válnak nemzetközi megállapodások tárgyává. A „,belügyek” nemzetközi szintre emelkedése egyrészt új megvilágításba helyezheti az adott kérdéseket, másrészt új szereplők megjelenését eredményezi az ügy megoldására törekvők közötti erőtérben. ${ }^{36} \mathrm{~A}$ nemzetközi terrorizmus akciói annak földrajzi szétterjedésén és a médiában való azonnali megjelenésén keresztül a korábbiaknál testközelibbé válnak. Az oly távolinak tartott diplomáciai és biztonsági kérdések folyamatosan egészülnek ki a civil társadalmat közelebbről érintő kérdésekkel, és válnak ezáltal egyre kézzelfoghatóbbá. A nem állami szereplők fokozódó aktivitása ebben a helyzetben arra készteti a kormányokat, hogy saját maguk is nyissanak a civil társadalom felé, és megpróbálják számukra kedvező módon befolyásolni, alakítani a közvéleményt.

Az államok részéről a „társadalmi diplomácia” (public diplomacy) lehet az egyik olyan eszköz, amelynek segítségével megvalósítható, hogy a klasszikus állam-állam viszonyrendszerből kilépve a nem állami szereplők álláspontját és tevékenységét alakítsa. A public diplomacy kifejezés - bár definíciója folyamatosan bővül - 1965-ből, Edmund Guillontól származik. A Murrow Center akkori kiadványa szerint a public diplomacy „a társadalmi magatartás befolyásolását célozza más országokban”. 1987ben az amerikai külügyminisztérium már „más országok közvéleményének tájékoztatása és befolyásolása"-ként említi. 1997-ben a United States Information Agency „,a külföldi társadalom megértése, tájékoztatása és befolyásolása” kifejezést használja. ${ }^{37}$ 2008-ban Glassman, amerikai külügyi államtitkár még tovább bővíti a definíciót, amikor arról beszél, hogy a public diplomacy feladata ,a külföldi közvélemény megértése, tájékoztatása, megnyerése és befolyásolása". ${ }^{38} \mathrm{~A}$ definíció bővülése jól mutatja, hogy az állam - nem állami szereplő kapcsolatrendszer folyamatosan alakul, és az államoknak az egyirányú közléstől el kellett, és még inkább

\footnotetext{
${ }^{36}$ A belpolitika külpolitizálódásáról lásd részletesebben Kiss J. (2009).

${ }^{37} \mathrm{http}$ ://www.publicdiplomacy.org, 2009. február 17.

${ }^{38}$ Briefing on U.S. Public Diplomacy and the War of Ideas http://www.state.gov/r/us/2008/111372.htm, 2008.október 28.
} 
el kell majd mozdulnia a jövőben a kétirányú kommunikáció felé, amennyiben hatékonyan kívánják befolyásolni a nem állami szereplőket.

Akárcsak maguk a nem állami szereplök, a társadalmi diplomácia eszközeivel az államok is tematizálnak, sőt támogatásokkal, megszerezhető forrásokkal igyekeznek befolyásolni az NGO-k érdeklődési területét, aktivitását. Ennek extrém esete a szinte kizárólag állami forrásokból fenntartott „nem állami szereplök” tevékenysége, ami erősen megkérdőjelezi müködésük függetlenségét és ezáltal a civil társadalom szempontjából valódi hozzáadott értékét. Ez a problematika visszaköszön a definíció megfogalmazásakor: a többségében állami forrásból finanszírozott szervezeteket sokan nem tekintik valódi nem állami szereplőnek, ám a finanszírozás elfogadható mértékéről nincs egységesen elfogadott nézet.

A társadalmi diplomácia nagy hangsúlyt helyez a közvélemény alakítására - nem összekeverve azt a propagandával. Ennek közvetlen eszköze lehet a nyilvános szereplések számának növelése és tartalmának mélyítése, valamint közvetett eszköze a média tudatosabb és sokoldalúbb használata a megfelelö üzenetek eljuttatása érdekében. Egy-egy ország megítélésének alakítása ma már nem monopolizálható, ahogyan egyegy nemzetközi megállapodás államok közötti elfogadása sem automatikus, és ahogy a nemzeti vagy nemzetközi szabályozások alakítása sem kizárólagos jog. A hiteles kommunikáció a különböző kormányzati, illetve tágabb értelmezésben állami szereplők összehangolt cselekvésén múlik. A kommunikációs csatornák és a transznacionális szereplők számának emelkedésével - ami nagyrészt a kommunikációs költségek rohamos csökkenésének tudható be - az állami szereplök már egyre kisebb mértékben képesek ellenőrizni a transznacionális információáramlás tartalmát. Márpedig a felduzzadt és felgyorsult információfolyam befolyásolásához egészen más megközelítésre lesz szükség az államok részéről, akik mint a kommunikáció jelenleg még meghatározó, de már messze nem kizárólagos résztvevői igyekeznek álláspontjukat érvényre juttatni.

A nem állami szereplők az állami ellenőrzés és ráhatás csökkentése, illetve ellensúlyozása mellett gyakran annak kihasználására, befolyásolására törekszenek. Céljaik elérése érdekében szükségük van az állami képességek minimális szintjére, mivel azon keresztül is biztosíthatják céljaik elérését. Haas (1990) a környezetvédelmi szabályozás példáján keresztül mutatja be, hogyan sikerült egyes transznacionális nem állami szereplőknek aktív tevékenységük eredményeként az állami szabályozás megváltoztatása segítségével más, profit-orientált piaci szereplők müködését 
befolyásolni. Az állam mozgásterének szűkítésére jó példa ugyanakkor a németországi, illetve nyugat-európai békemozgalmak hatása, ami a biztonságpolitika hagyományosan állami felségterületére terjesztette ki a társadalmi szereplők ráhatását. (Rochon 1988) A kérdést tehát egyik irányba sem lehet egyértelműen eldönteni. A nem állami szereplők képesek valamilyen mértékben befolyásolni az államok magatartását, sőt bizonyos esetekben azok tevékenységét a maguk javára ki is tudják használni, de ez a képességük elsősorban a megfelelő koalíciók létrehozásától - Risse-Kappen szavaival élve: „winning coalitions” - és a nemzetközi támogatás biztosításától függ. (Risse-Kappen 1995, p. 296)

A nem állami szereplők befolyása a transznacionális kapcsolatokra nagymértékben függ ugyanakkor a nemzeti struktúrák és a nemzetközi szervezetek kapcsolatának szorosságától is. Ahogyan arra Risse-Kappen ugyancsak rámutat, minél nagyobb mértékű egy kérdéskör nemzetközi szabályozása, minél aktívabbak az adott területen a nemzetközi szervezetek, annál több csatorna áll a nem állami szereplök rendelkezésére az állami szint közvetett befolyásolására. (Risse-Kappen 1995) Ennek magyarázatát a nem állami szereplők és a nemzetközi szervezetek kapcsolatának vizsgálatakor részletesebben elemzem.

\subsection{Az államok feletti szinten}

Az állami döntések csak a legritkább esetben történnek a nemzetközi tértől hermetikusan elzárt belpolitikai keretek között. Egy állam külpolitikai aktivitása - de egyre nagyobb mértékben a belpolitika külpolitizálódása miatt a belpolitika is - a nemzetközi erötérben alakul. Alig találunk ma olyan országot, amely nem tagja egy vagy több nemzetközi szervezetnek, és nincs olyan ország, amely ne bírna formális vagy informális együttmüködési hálóval.

A nemzetközi szervezetek ,állandó és kapcsolódó (formális és informális) szabályrendszerek, amelyek meghatározzák a viselkedési normákat, korlátozzák a cselekvést és alakítják a várakozásokat.” (Keohane 1989, p. 3) Márpedig ha a nemzetközi együttműködés, illetve a nemzetközi szervezetek befolyással bírnak az államok döntéseire, akkor a nemzetközi szervezetek egyúttal csatornát is jelenthetnek a nem állami szereplők számára az érdekérvényesítésre: a nemzetközi folyamatoknak, illetve más nemzetközi szereplők aktivitásának befolyásolására. Ez azonban csak hozzáférést jelent a politikák alakításának folyamatához, egy potenciális lehetőséget, 
ami nem minden esetben jár sikerrel. A hozzáférés, a befolyásolás lehetősége önmagában még semmi esetre sem jelenti a befolyásolás képességét. Az, hogy ezen a csatornán keresztül milyen mértékben képesek a nem állami szereplök - konkrét és átvitt értelemben is - keresztülvinni akaratukat az adott nemzetközi szervezeten, illetve nemzetközi kapcsolatrendszeren, az jelentős mértékben annak intézményesülésétől függ.

Risse-Kappen (1995) megállapítja, hogy az egyes politikák alakítására vonatkozó állami autonómia és kormányzati képesség a nemzetközi kormányzati struktúrába való beágyazottság függvénye. A nemzetközi intézményrendszer tehát egy kívülről érkező hatást jelent, ami befolyásolja az állam döntési képességét. Függően attól, hogy ez az intézményi struktúra mennyire kötött, a nem állami szereplök kisebb vagy nagyobb mértékben érhetnek el eredményt. Egy szabályozottabb, integráltabb intézmény azzal az attribútummal bír a nem állami szereplők szempontjából, hogy amennyiben az intézményben érvényesíteni tudják álláspontjukat, tematizálni tudják a számukra fontos kérdéseket, illetve kedvezö kimenetelt tudnak elérni a döntési folyamat során, akkor az eredmény nagy hatással lesz az abban részes államok cselekedeteire. A nemzetközi intézményrendszer egyben legitimációt is jelenthet a nem állami szereplőknek transznacionális koalíciók létrehozására. A nemzetközi kapcsolatrendszerben részes államok és azok belföldi nem állami szereplői természetes partnernek tekinthetik a nemzetközi együttműködés részesévé vált nem állami szereplőt.

A nem állami szereplők befolyásolási képességét a nemzetközi szervezetek szintjén tehát alapvetően két paraméter határozza meg: egyrészt a döntéshozatali folyamathoz való hozzáférés képessége, a nemzetközi intézményrendszerben való megjelenés képessége, másrészt magának a döntéshozatali folyamatnak a befolyásolási képessége. A nemzetközi együttműködés intézményesültsége, az intézmény integráltsága alapvetően meghatározza az abban részes - döntő mértékben - állami szereplők tevékenységének meghatározására való képességet. A következő alpontok az ENSZ, az ET és az EU példáján keresztül mutatják be a nem állami szereplők befolyásolási képességének lehetséges kimeneteleit a nemzetközi szervezetek szintjén.

\subsubsection{AzENSZ}

Minden bizonnyal az ENSZ az a nemzetközi szervezet, amely a legnagyobb mértékben és a legintézményesítettebb formában vonja be a nem állami szereplőket a jogalkotás 
folyamatába. ${ }^{39}$ Az ECOSOC eljárási rendjére vonatkozó szabályozás külön cikke (71) tartalmazza azt a kitételt, hogy „a Gazdasági és Szociális Tanács megfelelő eljárást biztosít azokkal a nem kormányzati szervezetekkel való konzultációra, amelyek érintettek a kompetenciájába tartozó ügyekben.” Ezáltal az NGO-knak lehetőségük van arra, hogy a vita során kifejtsék véleményüket, értékeljék a meglévő javaslatokat, vagy éppen új javaslattal álljanak elő, amennyiben annak létjogosultságát kellőképpen meg tudják indokolni. Részvételük pozitív hatását jól mutatja, hogy mind több bizottság vonja be munkájába a nem állami szereplőket, sőt 2003-ban Kofi Annan, akkori ENSZ fötitkár egy külön grémiumot kért fel arra, hogy megvizsgálják a civil társadalmi szervezetek jobb bevonásának lehetőségeit. A „Panel of Eminent Persons on United Nations - Civil Society Relations” 2004-re készítette el jelentését, amely megállapította, hogy az ENSZ-nek ahelyett, hogy egy olyan kormányközi szervezet lenne, amely alkalmanként elfogad érdemi hozzájárulást nem állami szereplőktől, olyan szervezetté kellene válnia, amely összehangolja a polgárok, az érdekképviseleti szervek, az üzleti világ, a helyi önkormányzatok és a parlamentek álláspontját. A jelentés rámutat arra, hogy a globalizáció hatására a határok átjárhatóvá válnak, az új kommunikációs eszközök megnövelik a közvélemény szerepét, és a demokrácia hagyományos intézményeit mind több kritika éri. Részben azért, mert míg a politika legfőbb színtere továbbra is a helyi vagy a nemzeti szint, ,napjaink legfontosabb csatáit - legyen szó éhínségről, szegénységről, írástudatlanságról, járványokról, terrorizmusról, kábítószerről, klímaváltozásról, természeti katasztrófáról, környezetvédelmi veszélyről, gyermekek és nők kizsákmányolásáról, vallási vagy etnikai megosztottságról, munkanélküliségről, gazdasági válságról avagy javak, hatalom vagy információ egyenetlen elosztásáról - nem lehet a kormányok szintjén megoldani.” (UN Report 2004)

A nem állami szereplök már nem területi alapon szerveződnek, hanem érdekcsoportokba, tematikus hálózatokba, és képesek nemzetközi szinten felhívni a figyelmet a számukra fontos témákra. Ezáltal rá tudják kényszeríteni az ENSZ illetékes szerveit arra, hogy az adott kérdéssel foglalkozzanak. Annak érdekében, hogy meg tudja örizni egyedülálló nemzetközi szerepét és morális tartását, az ENSZ-nek meg kell tanulnia alkalmazkodni ehhez a realitáshoz, és proaktívan fellépnie azokban a témákban, ahol a nem állami szereplők kiemelkedő szerepre tesznek szert, mint például a nemek közötti

\footnotetext{
${ }^{39}$ http://www.un.org 2009. március 23.
} 
egyenlőség biztosítása, klímaváltozás megakadályozása, adósságok elengedése, gyalogsági aknák felszámolása és az AIDS elleni küzdelem.

A jelentés azt is javasolja, hogy a nemzetállami befolyás legfontosabb bástyájának tartott Biztonsági Tanácsnak is mélyítenie kellene az együttmúködését a nem állami szereplőkkel, mert azok nagymértékben hozzájárulhatnak a modern konfliktusok kezeléséhez a konfliktus gyökereinek feltárásával, illetve a konfliktusok kezelésének a nemzeti szuverenitás miatt más államok által nehezen ellátható feladatainak átvállalásával. A civil szervezetek bevonásáról szóló döntést ugyanakkor szigorú kritériumokhoz, és végső soron állami döntéshez javasolják kötni, ami erősen korlátozza a nem állami szereplők érdemi részvételét.

További korlátozó tényező, hogy nem tisztázott a megfelelő érdekképviselet sem. Az ENSZ fogyatékosok jogainak védelméről szóló konvenciójának kidolgozására felállított Ad Hoc Bizottság tagjai kiválasztásának folyamata tökéletes példája a nem állami szereplök reprezentativitása megállapíthatósága nehézségeinek. Az ECOSOC az intézmény által elismert nem kormányzati szervezeteknek konzultatív státust biztosít. Csakhogy ebben az esetben - mint ahogyan az esetek többségében - csak korlátozott számú NGO élvezi ezt a privilégiumot. Felvetődik tehát a kérdés, hogy a jogalkotási folyamat hatékonyságának megőrzésével egy időben hogyan biztosítható a megfelelő szervezetek képviselete. Még egy szinttel lejjebb kezdve az elemzést, az a kérdés merül fel, hogy a jelentkező szervezetek közül melyek tekinthetőek reprezentatívnak, vagyis milyen elvek alapján ismernek el egy nem állami szereplőt az adott érdekek képviselőjeként. A fent említett esetben például a betölthető helyeket végül a földrajzi egyenlőség klasszikus elve alapján osztották szét, ami egy lehetséges, de ugyanakkor önkényes kiválasztási szempont. A nem kormányzati szervezetek jellegzetességéböl adódik egy másik jelentős nehézség is. Az NGO-k (de a nem állami szereplők általában) egy-egy speciális terület vagy részterület problémáival foglalkoznak, erősen specializáltak. Márpedig egy univerzális szabályozás a legritkább esetben teszi lehetővé a nagyon specializált megközelítést. Ebböl adódik, hogy gyakran a különböző szervezetek nem találják meg a közös nevezőt, illetve nagyon csekély számú szervezet tud érdemben részt venni az érdemi vitában. 


\subsubsection{Az Európa Tanács}

Az ENSZ-hez hasonlóan regionális szervezetek is együttmüködnek a nem állami szereplőkkel: az Európa Tanács eljárásrendjébe már 1952-ben bekerült az együttmüködés szabályozása, ami időközben jelentősen változott. A szabályozás megteremtette annak a lehetőségét, hogy a nemzetközi nem kormányzati szervezetek (INGO) részt vehessenek az Európa Tanács bizonyos fórumainak munkájában, ugyanakkor elvárásként fogalmazta meg, hogy a szervezet szócsöveként a nemzeti és szub-nemzeti szinteken az általa képviselt értékeket képviseljék.

Az együttmüködés csak a nem állami szereplők szük körére, a nemzetközi nem kormányzati szervezetekre terjedt ki. Kezdetben tanácskozási jogot biztosított számukra, ami idővel folyamatosan erősödött. Előbb 1972-ban a (72)35 számú határozat, majd az azt 1993-ban módosító (93)38 számú határozat rendelkezett a konzultatív státus tartalmáról. Ezek értelmében az ET felismerve a nem-kormányzati szervezetekkel való együttmüködés fontosságát, konzultatív státuszt biztosított azoknak a nemzetközi NGO-knak, amelyek saját tevékenységi területükön különösen reprezentatívak európai szinten, és képesek elősegíteni az ET szellemiségének terjesztését. Ezeket az NGO-kat a különböző bizottságok bevonhatták munkájukba, kikérhették véleményüket szóbeli vagy írásbeli formában az általuk képviselt témákban. Az ET döntése egyértelmü jele annak, hogy az intézmény felismerte, a nem állami szereplők véleményét nem hagyhatja figyelmen kívül. A nem állami szereplők elérték, hogy a folyamatok alakításába közvetlen módon beleszólást nyertek. Tevékenységük mindazonáltal kétirányú. Egyrészt a fent említettek szerint információkat és szaktudást csatornáznak be a civil társadalom felöl a Tanács megfelelő bizottságaiba, részt vesznek azok munkájában, amin keresztül érvényt szereznek saját céljaiknak, másrészt a Tanács munkáját, az elfogadott dokumentumokat, határozatokat minél szélesebb körben megismertetik azokkal, akikkel müködésük során kapcsolatba kerülnek.

2003-ban a (03)8 számú határozat a korábbiakhoz képest három kérdésben is elörelépést jelentett. Hangsúlyozta, hogy az addig elsődlegesen a Tanács által irányított együttmüködésen túl (információ-szolgáltatás illetve -terítés) a szervezet mind nagyobb mértékben számít az INGO-k kezdeményezéseire, általuk megvitatásra érdemesnek tartott témák napirendre tüzésére. A határozat megerősítette a transznacionális tevékenységet folytató NGO-k mellett a nemzeti NGO-k szerepének fontosságát, és a velük való együttműködés szükségességét. A nemzetközi nem-kormányzati 
szervezetekre vonatkozó korábbi konzultatív státuszt résztvevői státusszá alakította, amely aktívabb, kezdeményezőbb szerepvállalást tesz lehetővé és vár el a különböző NGO-któl mind az ET munkájára vonatkozó információk beszerzése, mind álláspontjuk becsatornázása, valamint a megszülető dokumentumok, standardok és képviselt értékek terjesztésében. A résztvevői státuszt élvező transznacionális nem-kormányzati szervezetek jelenleg 395-en tagjai a Nemzetközi Nem-kormányzati Szervezetek Konferenciájának, ami egyre nagyobb szerepet játszik az Európa Tanács tevékenységének alakításában.

„A résztvevői státusszal rendelkező transznacionális nem-kormányzati szervezetek 10 tematikus csoportot hoztak létre, amelyek a Parlamenti Közgyülés ülésszakának idején évente háromszor üléseznek, a következő csoportokban: Emberi jogok, Nemek közötti egyenlőség, Európai Szociális Karta és társadalompolitika, Kirívó szegénység és társadalmi kohézió, Oktatás és kultúra, Civil társadalom és demokrácia Európában, Egészségügy, Vidék és környezet, Városok, Észak-dél közötti párbeszéd és szolidaritás." ${ }^{40}$ Befolyásolási képességük növekedését mutatja, hogy megváltozott státuszuk, ami egyben lehetővé teszi a véleménynyilvánítás mellett az egyre szélesebb értelemben vett tematizálást is. A Tanács és az NGO-k közötti együttmüködés többféle formában valósul meg. Nyilatkozatokat tehetnek, az ET főtitkárának illetve a megfelelő bizottságok kérésére konzultációt folytathatnak, részt vehetnek és felszólalhatnak a Tanács szemináriumain, illetve a működési területükhöz tartozó projektek megvalósításában tevőlegesen is részt vehetnek. Ez a széleskörü együttmüködés jellemzőbb a nem állami szereplök és a nemzetközi szervezetek kapcsolatára, mint az államokkal való fentebb vázolt interakcióra.

\subsubsection{Az Európai Unió}

Az Európai Unió a nem állami szereplők tevékenységének egészen különös területe a szó szoros és átvitt értelmében. Az unió központjában, Brüsszelben több mint 150 NGO, 300 érdekképviselet és 15.000 lobbista tevékenykedik, akik egyszerre próbálják meg érvényesíteni érdekeiket a tagállami képviseletek és a szupranacionális európai intézmények szintjén.

\footnotetext{
${ }^{40}$ http://www.coe.int/T/E/NGO/Public/ 2009. március 20.
} 
A nem állami szereplők interakciója az Európai Unióval aktív és sokrétü, mivel az unió nagyon széles részvételi lehetőséget kínál számukra a döntéshozatali folyamatokban. A nem állami szereplök számára kínálkozó lehetőségeket azonban a közösségen belül versengő érdektörekvések bonyolult hálózatában kell érvényre juttatniuk, és eközben rendszeresen egymással és a tagállamokkal kell versenyezniük. Ugyanakkor a szubnemzeti szereplők (gazdasági, tudományos vagy társadalmi érdekképviseletek) gyakran a tagállami érdektörekvéseket is megjelenítik, így nem csupán közvetlenül, de közvetetten is bekapcsolódnak az uniós döntéshozatali folyamatokba.

A nem állami szereplők érdekei alkalmanként szembe mennek a tagállami érdekekkel, és a döntéshozatal befolyásolása során az államokkal szemben, és esetenként egymás rovására kell érvényesíteniük azokat. Ha egy nem állami szereplő meg tudja nyerni az uniós intézmények támogatását, akkor képes lehet saját tagállami kormányával szemben is sikeresen érvényesíteni álláspontját. Anélkül, hogy részletesen belemennénk az uniós intézmények és szereplök kölcsönhatásainak szövevényének ismertetésébe, érdemes megemlíteni azt, hogy a nem állami szereplők bevonása a kezdetektől fogva a közösségi intézmények - elsősorban az Európai Bizottság - tudatos stratégiája a tagállamokkal szembeni pozíciójuk erősítése érdekében.

Amint arra Simon (2009) Magyarország példáján rámutat, az európai uniós érdekérvényesítési folyamatban az érdekek közösségi megjelenítése már nem kizárólag állami-diplomáciai feladat, hanem az érintett gazdasági és társadalmi nem-állami szereplők számára létező kihívás.

A nem állami szereplök EU-val való együttmüködésének egyik kiemelkedő példája a segélyezési politika, ahol a humanitárius segélyek elosztásában és célba juttatásában játszanak fontos szerepet. Az EU által nyújtott segélyek elosztásában legfőképp NGO-k, de más nem állami szereplők és nemzetközi szervezetek (ENSZ, szakosított szervei és más nemzetközi szervezetek) is részt vesznek. Az elmúlt időszak adatai jól mutatják, hogy az NGO-k átlagosan a teljes EU által humanitárius segélyezésre fordított összeg több mint 50\%-ával rendelkeznek. A 2008-ban Európába is begyürüző válság hatására ismét az ENSZ vált a legnagyobb segélyezővé, de az NGO-k már a következő évben visszavették a vezető szerepet, és közel annyi pénz felett diszponálnak, mint az ENSZ és más nemzetközi szervezetek együttvéve. „Az NGO-k esetében a szerződések átlagos értéke 600 ezer euró körül van, a nemzetközi szervezeteknél 1,86 millió euró, míg az ENSZ-szervezeteknél 1,87 millió euró.” (Gömbös 2011, p. 148) Vagyis az NGO-k 
átlagosan harmad akkora projekteket valósítanak meg, de abból lényegesen nagyobb számút.

5. ábra: Az Európai Unió humanitárius segélyeinek elosztása

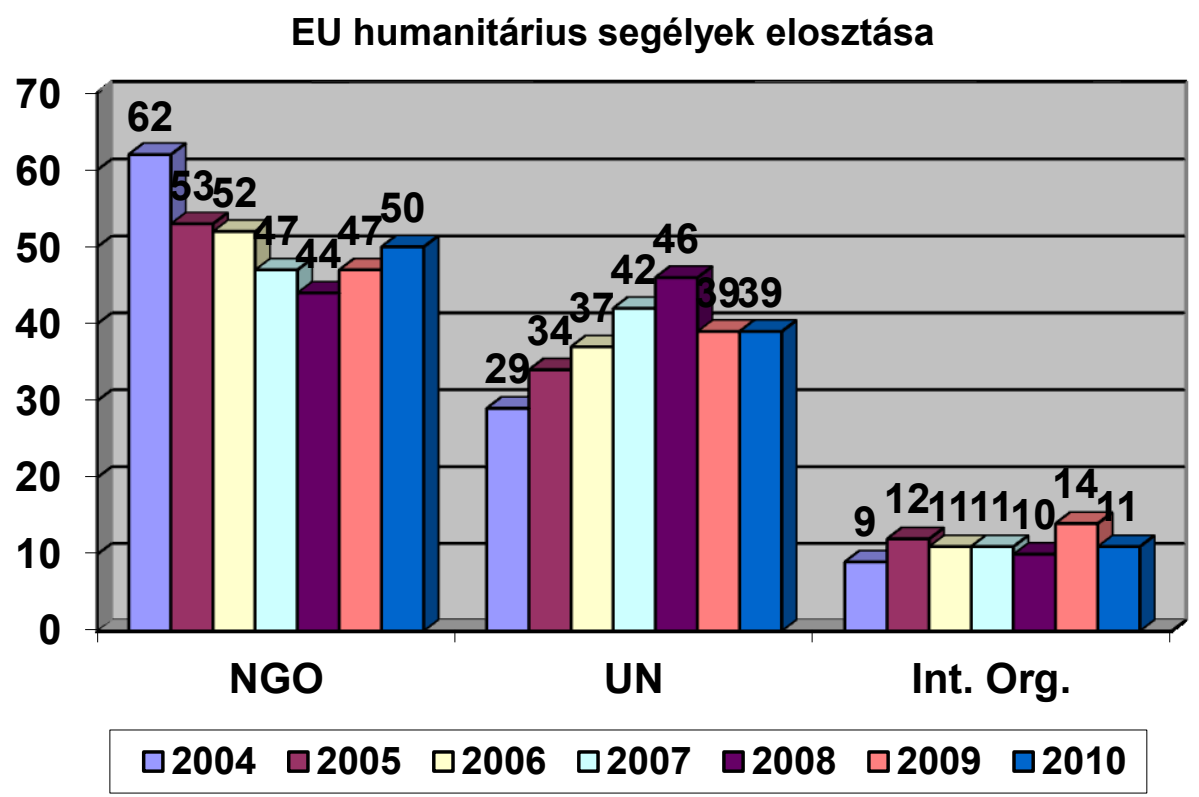

Forrás: DG ECHO

\subsection{Más nem állami szereplökkel szemben}

A transznacionális kapcsolatok bővülésével, a kapcsolatok hálózatosodásával egyre több kölcsönhatás jön létre különböző nem állami szereplök között. A hálózatok jellegéből adódóan a szereplők közötti érintkezések megsokszorozódnak, és azok intenzitása a hálózat többi résztvevőjétől függetlenül alakul. A nem állami szereplők egymásra való hatásának ezáltal közvetett módon nagy szerepe lehet a transznacionális folyamatok összességének befolyásolásában is. Fentebb láttuk, hogyan hatnak például a hitelminősítő intézetek a gazdasági szereplök döntéseire, és az hogyan hat az államok pénzügyi helyzetének változásán keresztül az egyes szakpolitikai kérdésekre. Hasonló folyamatnak lehetünk Hannon (2011) szerint tanúi a jövőben az Európai Unió szintjén. A nemzeti költségvetésekröl az Európai Bizottság által kiadott vélemény a „gyorstüzelésü” kötvény befektetők érzékenysége miatt ugyancsak jelentős mértékben visszahathat a tagországok pénzügyi mozgásterére. A Greenpeace akciói közvetlen hatást gyakorolnak a gazdasági szereplőkre, kampányai a jogszabályi környezet megváltoztatásán keresztül közvetetten befolyásolják azok müködését. A nem kormányzati szervezetek jellegzetességéből adódik közvetett egymásra hatásuk több 
nehézsége is. Az ICFTU 1996-os kampánya a foglalkoztatás feltételeinek szabályozása érdekében megmutatta, hogy az ellentétes érdekü NGO-k összeütközése során a képviselt részérdekek ki is olthatják egymást. A nem állami szereplők között kialakulhat ugyanolyan szembenállás, mint az érintett államok között. (O’Brian et al. 2000) Nem meglepő, ha egy NGO kezdeményezés ilyen esetben nem jár sikerrel.

A nem állami szereplök közötti direkt kölcsönhatásokon túl egyre nagyobb szerepet játszanak a szabályozási keretek alakításának folyamatai. Ezek közül az alábbiakban az állam és a nem állami szereplők befolyása, mint végpontok közötti spektrumon az állami befolyástól a nem állami felé haladva a három legfontosabbat vesszük górcső alá:

1) Public-private partnership (PPP)

A fejlett országok és az általuk dominált nemzetközi pénzügyi intézmények által követett és közvetített neoliberális gazdaságpolitika a piacok megnyitását, a szabadpiaci intézmények kiépítését célozza. A privatizáció, a liberalizáció és a decentralizáció az állam szerepének csökkentését erősíti, és az állami szereplőket arra ösztönzi, hogy befolyásuk megőrzése érdekében olyan új együttmüködési formákban gondolkodjanak, amelyek lehetővé teszik a nem állami szereplők érdemi befolyásolását. (Rosenau 2000) Az állami és a magán szféra együttmüködésének az állam által kezdeményezett formája a PPP. Mindenekelött meg kell különböztetnünk a közpolitikák területén történő együttmüködést (Public-private policy partnership - PPPP) és az egyes projektekre létrejövő együttmüködést (Public-private partnership - PPP). Előbbi jellemzően az oktatás, egészségügy, környezetvédelem, energiagazdálkodás és a büntetés végrehajtás területén valósul meg. Utóbbi általában nagyobb infrastrukturális beruházások, leggyakrabban közlekedési projektek esetében jön létre. Míg a PPPP elsősorban az Egyesült Államokban elterjedt, Európában történelmileg a szociális és környezetvédelmi védőháló biztosítása állami feladat. A PPP ugyanakkor hagyományosan Európában gyakoribb, bár megítélésének változása jól megfigyelhető az Egyesült Államokban is. Ázsia és Afrika ebből a szempontból nehezen besorolható, a 21. században mindkét megközelítés kezd nagyobb mértékben elterjedni.

A PPP/PPPP földrajzi régiótól függetlenül nem új jelenség. A zsoldoshadseregek tevékenysége, vagy a börtönök müködtetése történelmi távlatokra nyúlik vissza. Az évszázadok során pedig többször változott, hogy mely tevékenységek voltak kizárólag állami kézben, és melyeket adott ki az állam kezelésbe valamilyen együttműködési formában. Az állam által ellenőrzött, de nem állami szereplők által elvégzett feladatok száma az utóbbi évtizedekben jól megfigyelhetően emelkedik. A szabad világban már 
az 1980-as évek elejétől, a felbomló szovjet térségben az 1990-es évektől, a fejlődő világban pedig a 2000-es évektől mutatható ki látványos növekedés ebben a tekintetben. Természetesen vita van arról, hogy mely tevékenységeket, közpolitikákat vagy projekteket képes hatékonyabban megvalósítani az állam, illetve egy profit-orientált vagy egy non-profit nem állami szereplő. Az együttmüködés fejlődését vizsgálva megállapítható, hogy hagyományosan az államok profit-orientált vállalkozásoknak adtak át közfeladatokat, majd a 20. század második felében a nem-kormányzati szervezetek váltak kitüntetett együttmüködő partnerré, és jelenleg ismét visszarendeződést figyelhetünk meg a vállalkozások irányába. Az állami és a nem állami szereplök (megkülönböztetve a profit-orientált és a non-profit szervezeteket) tevékenysége elvben kiegészíthetné egymást, mivel különböző erősségekkel bírnak. Így más-más területeken tudnak hatékonyan fellépni. Osborne és Gaebber (1992) az alábbiak szerint foglalja össze az egyes szereplők erősségeit:

- Állami szereplő: figyelembe veszi a szolidaritás elvét, átláthatóságot biztosít, irányítja a szabályozási folyamatokat. Olyan területeken lehet meghatározó, ahol sok a közjószág, pl. alap szociális ellátás, környezetvédelem.

- Profit-orientált nem állami szereplő: dinamikus, kreatív, hatékony, fejlődést generál. Domináns lehet a gazdaságban, a technológia és innováció területén.

- Non-profit nem állami szereplő: elkötelezettség, bizalmi alapú együttmüködés. Specializált kérdésekben tud hatékonyabban fellépni a célzott tanácsadástól a speciális igényü beteggondozásig.

A feladatmegosztás azonban nem ideális elvek alapján valósul meg, így nem kerülhető el a duplikáció és a konfrontáció sem. A globális térben megjelenő lokális igények, illetve a transznacionális kapcsolatok speciális igényeket jobban kielégíteni képes jellege véleményem szerint összességében erősíti a nem állami szereplők által hatékonyabban lefedhető területek, így maguknak a nem állami szereplöknek a jelentőségét. Nem kérdőjelezi meg ugyanakkor az állam szerepvállalását.

2) Önkéntes szabályozás

A nem állami szereplők magatartását alakító önkéntes szabályozások ugyancsak a Vesztfáliai rendszer előtti időre nyúlnak vissza. A különböző vallási rítusok, hagyományok, kereskedelmi szokások mind ebbe a kategóriába sorolhatók. A modernkori történelmet tekintve kiemelésre érdemes ebben a tekintetben a National Consumers League 1899-es létrehozása, ami a munkahelyi biztonság megteremtésében játszott szerepet, illetve az International Chamber of Commerce 1937-ben elfogadott 
reklámozási szabályzata. Webb (2002) négy pontban foglalja össze az önkéntes szabályozás definícióját:

1. A szabályozást nem jogszabály írja elö;

2. Azt legalább egy személy vagy szervezet magára nézve elfogadja;

3. Célja az érintettek viselkedésének befolyásolása, szabályozása;

4. Azt konzisztensen alkalmazzák, annak következménye kiszámítható.

Érdemes különbséget tenni a történelmileg létezett önszabályozás, és annak a modernkori megfelelöje között. A nem állami szereplök befolyásának alakulása szempontjából ugyanis fontos eltérés, hogy míg korábban az önkéntes szabályozás elsősorban azokon a területeken jelent meg, ahol az állam nem alkotott szabályozást, addig ma egyre jellemzőbb olyan kérdésekben is, ahol az állam nem képes betartatni az általa kialakított szabályokat. A komplementer magatartás mellett ugyanakkor növekvő jelentőségre tesz szert a kompetitív cselekvés. Ezeken a területeken de facto megkérdőjeleződik az állam kizárólagos vagy domináns befolyása.

$\mathrm{Az}$ önkéntes szabályozás klasszikus példája a Vállalatok Társadalmi Felelőssége (Corporate Social Responsibility - CSR). A foglalkoztatási, fogyasztóvédelmi, környezetvédelmi, stb tudatosság növekedésével a vállalatok számára gazdaságilag kifizetődő lehet ezeknek a kérdéseknek tudatos, kiemelt kezelése, és tevékenységük során tudatosságuk bemutatása. A globalizálódó társadalmakban ezek az értékek mind nagyobb számú fogyasztót szólítanak meg, így az adott vállalat termékei potenciális vásárlóinak száma is növekszik. Vogel (2005) nemzetközi jelenléttel bíró vállalatok vizsgálatán keresztül rámutat arra, hogy a CSR egy bizonyos mértékben hozzájárulhat a vállalat megítélésének javításához, de hangsúlyozza ennek korlátait. Vizsgálata rámutat arra, hogy nincs korreláció a vállalatok társadalmi felelőssége és gazdasági teljesítménye között. Végső soron a vállalatok számára a CSR csak annyiban vonzó, amennyiben az hozzájárul a profit termeléséhez.

$\mathrm{Az}$ önkéntes szabályozás a transznacionális gazdasági kapcsolatok számának növekedésével azonban gyakran vált ki határokon átnyúló hatást az érintett társadalmak közötti különbségek miatt. Ennek eklatáns példája a vállalatok belső szabályozásának a külföldi telephelyet vagy leányvállalatot befogadó állam szabályozására gyakorolt közvetlen hatása. Amennyiben ugyanis előbbi szigorúbb előírásokat tartalmaz, úgy a gyakorlatban az adott állam szabályozásánál szigorúbb követelmények nyernek teret. Figyelembe véve, hogy a vállalatok többségében épp a kedvezőbb, enyhébb szabályozású országok irányába terjeszkednek, az önkéntes szabályozásnak - 
függetlenül annak indokától - pozitív hatása lehet. Az önszabályozásra vonatkozó kezdeményezés származhat maguktól a nem állami szereplőktől, de valamely államtól is. Ezen túlmenően az államok indirekt módon is képesek ösztönözni azt. Webb rámutat arra, hogy amennyiben az állam kilátásba helyezi egy szabályozás megalkotását, de nem lépi azt meg, a bizonytalanságban rejlő lehetőség arra késztetheti az érintett szereplőket, hogy megpróbáljanak számukra kedvezőbb önkéntes szabályozást kialakítani, elkerülve ezzel egy szigorúbb állami szabályozás bevezetését.

Nye (2011) megállapításával egyetértve azt állítom, hogy a vállalati önszabályozás nem jelent közvetlen kihívást az államok szuverenitására, csak a transznacionális kapcsolatok olyan új szintjét jelenti, ahol az állam nem rendelkezik teljes ellenőrzési képességgel. Ennek bővülésével az állami befolyás relatív értelemben csökken.

3) Piaci szabályozású kormányzási rendszer (Market Driven Governance System - MDGS)

A nem állami, piaci szabályozású kormányzási rendszer elsősorban ott alakul ki, ahol elégtelen a nemzeti és a nemzetközi szabályozás. Jellemzője, hogy a termelési és értékesítési lánc minden, vagy meghatározó számú tagja részt vesz benne, elfogadja annak közösen kialakított szabályait. (Bernstein - Cashore 2007) Minden szereplő önkéntesen csatlakozik a rendszerhez, majd követő magatartást folytat. Ezt megkönnyíti, hogy a vonatkozó szabályok alakításába beleszólása lehet, azokat nem egy külső szereplő - pl. állam - kényszeríti rá a résztvevő nem állami szereplőkre, hanem a szabályozás alanyai maguk alakítják azokat. Maga a szabályozás kezdeményezése sem az államtól származik. Az érintett nem állami szereplök kölcsönhatásai következtében, azok során indul el a müködési keret kialakítása. Elsődleges cél a piac müködésének a társadalom elvárásainak a lehető legnagyobb mértékben megfelelő módon történő biztosítása. Ruggie rámutat az MDGS egyik legfontosabb tulajdonságára, hogy a rendszer nem egyszerűen a termelési és értékesítési lánc tagjai érdek alapú lépéseinek összessége, hanem a kölcsönhatások alapján közösen kialakított szabályrendszerhez igazított lépések együttese. Utóbbi eredménye több mint az önérdekü lépések eredője. (Ruggie 2004) A globalizáció következtében a határokon átnyúló gazdasági kapcsolatok mind több transznacionális gazdasági szereplöt kötnek össze ilyen típusú szabályozási rendszerek keretein belül. Ezáltal maguk a rendszerek is transznacionálissá válnak. A transznacionális jellegből is adódóan az államok befolyásolási és szabályozási képessége korlátozott. Az MDGS legitimációját nem külső autoritás biztosítja, hanem az abban résztvevők önkéntes követő magatartása, amit egyéni érdekeiken túl - amint 
fentebb megfogalmaztuk - az is motivál, hogy hatással bírnak a rendszer müködési szabályainak alakítására. 


\section{FEJEZET}

\section{A NEM ÁLLAMI SZEREPLŐK ADOTTSÁGAINAK VÁLTOZÁSA}

A nemzetközi rendszer strukturális átalakulása, valamint az információs és kommunikációs forradalom a transznacionális hálózatok alakulásának köszönhetően erősíti a nem állami szereplöket. De nemcsak a nemzetközi környezet változott meg, amelyben az egyes aktorok - így a nem állami szereplők is - érvényesíteni próbálják érdekeiket, és nemcsak a befolyás érvényesítésének eszközei, illetve azok alkalmazásának arányai módosultak az elmúlt évtizedekben. A nem állami szereplők saját képességei is jelentős mértékben fejlődtek.

\subsection{Képességek változása}

Egyik, és talán a legfontosabb - ami a globalizáció felgyorsulásához is alapvetően hozzájárult - a kommunikációs képességek óriási fejlődése. Törő (2000) helyesen mutat rá arra, hogy a kommunikáció és a koordináció költségeinek drasztikus csökkenése óriási mértékben megkönnyítette a nem állami szereplők számára a politikai határokon átnyúló, transznacionális müködést. Keohane és Nye (1977) a hálózatok fejlődésének három elemét jelöli meg legfőbb okokként: a hálózati kapcsolatok számának és sürüségének növekedését, az intézmények fejlődési sebességének növekedését és a hálózatokban résztvevők nemzetköziesedését. A hálózatok résztvevői ugyanis anélkül tudnak együttmüködni, hogy hosszadalmas és költséges procedúrák során felépített állandó intézményi struktúrát, hierarchiát kellene létrehozniuk. A „szervezet” bővülése folyamatos lehet, fizikai korlátoktól mentesen kizárólag az adott közös érdeklődési kör vagy cél mentén szerveződik.

A másik tényező a nem állami szereplők rendelkezésére álló források növekedése, amely egyfelöl a müködéshez való pénzügyi hozzájárulások emelkedéséből, másfelöl a szervezetek illetve hálózatok résztvevői számának növekedéséből adódó emberi erőforrás bővülésből tevődik össze. Állandó kritika tárgya a nem állami szereplők tevékenységének finanszírozása. A finanszírozási forrástól függően ugyanis felvetődik a függetlenség kérdése. Finanszírozásuk mennyiben ellenőrizhető, és a finanszírozás forrása hogyan hat vissza a függetlenség és a reprezentativitás kérdéseire? Érdemes 
különbséget tenni a partikuláris érdektörekvéseiket érvényesíteni kívánó szereplők, valamint a közérdeket képviselö érdekszerveződések között. Ez nem releváns kérdés a legtöbb gazdasági szereplö, vagy éppen a terrorista szervezetek esetében. Probléma ugyanakkor a különböző érdekképviseletek esetében, amelyek külső finanszírozásra szorulnak, ami felveti a külső befolyásolás kérdését. Mennyiben tekinthető önálló transznacionális szereplőnek egy nagyrészt államilag finanszírozott nem állami szereplő, vagy az Európai Bizottság anyagi támogatását élvező, az Európai Unió szintjén folyó érdekképviseletre szakosodott szubnemzeti szereplő? A finanszírozás növekedésével a nemzetközi, illetve transznacionális nem állami szereplők köre folyamatosan bővül. Egyrészről megfigyelhető az a tendencia, hogy a kérdések nemzetköziesedését kis késéssel követve a szubnacionáis szereplők megjelennek a nemzetközi arénában, másrészről pedig az újonnan megjelenő nemzetek feletti problémák, illetve lehetőségek életre hívnak új nemzetközi vagy transznacionális nem állami szereplőket. E szereplők köre szinte kimeríthetetlenül széles: a transznacionális vállalatoktól kezdve a nemzetközi érdekképviseleti szervezeteken át egészen a nemzetközi terrorista szervezetekig.

A harmadik tényező a szakértelem, az adott témában összegyüjtött tudás. Mivel a nem állami szereplők nagy része egy-egy területre specializálódik, illetve egy-egy probléma napirendre tűzésére, megoldására jön létre, érthető, hogy az adott kérdésben akár még az állami szerveknél is alaposabb, részletesebb információkkal, és ennek köszönhetően nagyobb reputációval rendelkezik. Nem véletlen például, hogy amikor a nemzetközi környezetvédelmi NGO-k tematizálni kezdték a globális felmelegedés kérdését, és kritizálni az Egyesült Államokat hatalmas olajfogyasztása miatt, Washington elzárkózása a probléma érdemi kezelésétől, és ennek látványos megnyilvánulásaként a Kiotói Egyezmény ratifikálásának elmaradása lehetőséget teremtett a kérdéssel foglalkozó nem állami szereplőknek, hogy egy olyan állammal szemben mint az Egyesült Államok megjelenítsék érdekeiket, és rontsák az ország megítélését.

Ezen szereplők esetében kiemelkedő jelentősége van a kommunikációs eszközök alkalmazásának. A média szerepének és hatásának exponenciális növekedése új lehetőségeket teremt. A nemzetközi közvélemény kialakulása és folyamatos formálása képességének felismerése a nem állami szereplők számára fontos fejlemény, és ennek hasznosítása óriási esély. Amint arra Halliday (2001) már korábban felhívta a figyelmet, a média befolyása a társadalomra, illetve a politikai és kormányzati dötéshozatalra kettős. Egyrészt a nemzeti média hatással van a hazai közvélemény és a politikai témák 
formálására. Az állam külpolitikájának alakításakor a kialakult hazai véleményeket, illetve egy-egy téma iránt megnyilvánuló hangulatot figyelembe veszi, figyelembe veheti. Sok esetben a kormány mozgástere nemzetközi kérdésekben leszükül a média által gerjesztett belpolitikai vélemények miatt. Más esetekben természetesen ennek ellenkezője is lehetséges, a kormány megerősítést is kaphat egy nemzetközi kérdés képviseletéhez, vagy szélsőséges esetben szükségét érezheti egy külpolitikai lépés megtételének a jelentős hazai nyomás miatt. Ennek klasszikus példájaként szokták említeni Nagy-Britannia EU-politikáját, és az Egyesült Államok nemzetközi katonai szerepvállalását. Másrészt a média hatást gyakorol az állami szereplök nemzetközi vonatkozású döntéseire az úgynevezett „CNN-hatás”-on keresztül is. Ennek jellemzően az 1970-es évektől lehetünk tanúi. Sokan a BBC-t teszik felelőssé, illetve éltetik az iráni sah 1979-es bukásáért, és a CNN-t az amerikai döntés meghozataláért az 1995-ös boszniai beavatkozásról. Kevesebb szó esik róla, de potenciális hatásában semmivel sem kisebb jelentőséggel bír az Al-Jazeera televízió 2003-as megalakulása. Az AlJazeera regionális transznacionális nem állami szereplőként az arab világ egészére kiterjedő társadalom- és politika-formáló képességgel bír, amit részben épp a két fenti médiával szembeni meghatározottsága erősít. Ez - amint arra a későbbiekben még kitérek - azért is figyelemre méltó, mert a fejlődő világban a nem állami szereplők száma és fejlettsége lényegesen elmarad a fejlett országokban tapasztalható szinttől.

A nem állami szereplők megjelenése a médiában nehezen korlátozható. Az egyes események hírértéke magas, és a nem állami szereplők megfelelő partnerek a média hírigényének kielégítésében. Kétségtelen, hogy a nemzetközi jelenléttel bíró média befolyása az elmúlt évtizedekben érzékelhetően megnőtt, ami felveti egyben azt a kérdést is, hogy az mennyire tekinthetö önmagában cselekedni képes nem állami szereplőnek, avagy csak a más nem állami szereplők véleményének felerősítőjének. A média sok esetben állami szereplőnk tekinthető, de a legtöbb esetben nem állami szereplő. Felmerül a kérdés, hogy mennyire függetlenek a nem állami tévécsatornák az állami szereplőktől - gondoljunk csak a vonatkozó állami szabályozásokra, a reklámbevételekre, stb. Bizonyosan lehet példát találni mindkét elmélet igazolására és cáfolatára is. Tény, hogy a média sok esetben az állami és a nem állami lét határán mozog, ugyanakkor az is bizonyos, hogy a döntéshozatali folyamatokat mindkét esetben érdemben képes befolyásolni nem állami vélemények becsatornázásával. A hagyományos média (sajtó, rádió és televízió) továbbra is fontos szerepet játszik a különböző nemzeti és nemzetközi politikák alakításában. Ezzel párhuzamosan a 
kommunikációs technológia fejlődése és költségeinek csökkenése olyan kiterjedt nemzetközi hálózatok kialakulását segítette elö, amik már a hagyományos média szelektíven tematizált hatásán túlmutatva nemzetközi szinten is mérhető megjelenést tesznek lehetővé bármely területen tevékenykedő nem állami szereplők számára. Erről korábban írtam a 4.2. Hálózatok évszázada alfejezetben.

A szakpolitikák, és gyakran a korábban belpolitikainak tekintett témák külpolitizálódása felértékeli a nemzetközi szakértelem és információ-birtoklás jelentőségét. „A nagyfokú bizonytalansággal jellemezhető globális témák megjelenése (környezetvédelem, emberi jogok, pénzügyi instabilitás, bünözés) az egyes nem állami szereplök által birtokolt információkat nagyon értékes árucikké tette, és a tudományos vagy más szakértői közösségeket az előtérbe helyezte.” (Josselin - Wallace 2001, p. 9.)

Az államok nem monopolizálják tovább a nemzetközi kapcsolatok minden területét lefedő tudást, mint a vesztfáliai rendszerben. Csak bizonyos területeken őrzik meg domináns helyzetüket, más területeken befolyásuk csökken, és partneri vagy versenytársi helyzetbe kerülnek a nem állami szereplőkkel.

A nem állami szereplők befolyása ugyanakkor nem univerzális. Szemben az államokéval, az szinte minden esetben egy adott területre koncentrálódik. Érdekérvényesítési törekvéseik során az adott területeken már nemcsak közvetlenül az államokkal szemben lépnek fel, hanem mind nagyobb mértékben használják ki a nemzetközi fórumok nyújtotta lehetőségeket. Az államok igyekeznek kihagyni a nem állami szereplőket a döntéshozatalból azokon a területeken, amelyeken számukra az nem jelent hozzáadott értéket. Az esetek többségében még képesek dönteni arról, hogy együttmüködnek-e azokkal, bár a nemzetközi szervezetek szintjén már nem képesek érdemben korlátozni a nem állami szereplök befolyását. A nemzetközi szervezetek többsége valamilyen formában bevonja azokat a munkájába: konzultatív státusz vagy más részvételi lehetőség formájában.

\subsection{A befolyás növekedése egyes területeken}

A szakirodalom a nem állami szereplők tevékenységének, illetve tevékenységük hatékonyságának elemzésekor leggyakrabban egy-egy területre, azon belül is konkrét esettanulmányokra koncentrál. A lista igen hosszú, és folyamatosan bővül: a nemzetközi egyezmények szövegezésében való részvétel (ENSZ) a gazdasági szereplők érdekeinek figyelembe vétele a szabályozásban (TRIPs), a tüntetők képessége államközi 
konferenciák megakadályozására (WTO), a terrorista szervezetek tevékenységének az államok biztonságára gyakorolt hatása, stb. (Arts 2003, Dale 2001, Korey 1998)

A következőkben három olyan területet veszek sorra - a teljesség igénye nélkül, természetesen -, amelyeken véleményem szerint a nem állami szereplők szerepe a leglátványosabb mértékben növekszik, és amelyek egyben elemzési keretet is adnak ahhoz, hogy egyúttal bemutassam az interakciók három legfőbb kategóriáját. A befolyás növekedése ugyanis a többi szereplőhöz való viszony szempontjából három fö irány mentén valósul meg: lehet kooperatív, kompetitív vagy konfrontatív. Első esetben a másik szereplővel együttmüködve, egymás tevékenységét segítve, kiegészítve, a másik hatáskörét nem megkérdőjelezve vállal feladatot az adott nem állami szereplő. Második esetben ugyanazt a feladatot kívánja ellátni, ugyanazt a hatáskört kívánja megszerezni, de még mindig nem törekszik a másik szereplő hatáskörének átvételére, abszolút hatalmának csökkentésére. Harmadik esetben ellenérdekelt felek közötti kölcsönhatásról beszélünk, amikor az adott nem állami szereplő más - állami vagy nem állami - szereplő funkcióját, jogosultságait, adott entitások vagy terület felett gyakorolt jogait szerzi meg érdekütközés során.

Sokan sokféle területet azonosítottak be, és vizsgáltak részleteiben. Alább néhány fontos megállapítást teszek, utalok más szerzők korábbi munkáira, majd három kiválasztott példán keresztül bemutatom a nem állami szereplők aktivitásának és befolyásának növekedését. Strange (1996) például, aki megkérdőjelezi a nemzetközi kapcsolatok és a nemzetközi politikai gazdaságtan alapfeltevését az állam központi szerepéről, a területek között vizsgálja a maffia, a kartellek, a telekommunikációs vállalatok, a biztosító cégek és a globális könyvvizsgáló cégek szerepét. A RisseKappen (1995) szerkesztésében megjelent tanulmányok az MNC-k, a biztonságpolitikai szervezetek, a transznacionális szociális mozgalmak és a környezetvédelemmel foglalkozó nem állami szereplők befolyását mutatják be. Az ENSZ szerint a legfőbb területek, ahol a nem állami szereplők hozzáadott értéket biztosítanak: a nemek közötti egyenlőség biztosítása, a klímaváltozás megakadályozása, az adósságok elengedése, a gyalogsági aknák felszámolása és az AIDS elleni küzdelem.

A nem állami szereplők befolyásának egyik első látványos területe volt a környezetvédelem, ami az 1960-as évektől kezdődően került a figyelem középpontjába. Az a felismerés, hogy a környezeti problémák jelentős része nem ismer államhatárokat, szükségessé tette a hatékonyabb nemzetközi együttmüködést. Ugyanakkor a környezetvédelmi problémák előtérbe helyezése nagyon sok esetben a gazdasági 
versenyképesség csökkenéséhez, és áttételesen a szociális biztonság valamint jólét csökkenéséhez vezethet. Éppen ezért a kormányok nem szívesen vállalnak magukra és vállalataikra, lakosaikra nézve potenciálisan negatív hatású kötelezettségeket. Ezt a kormányok által akaratlagosan fel nem vállalt szerepet töltik be a nem állami szereplők, amelyek közül a Greenpeace nevü szervezet neve hangzik el leggyakrabban. Mint korábban említettem, a civil szféra pozitív szerepének elismerésében óriási jelentősége volt annak, hogy a Greenpeace 1992-ben tevőlegesen részt vehetett a Rio de Janeiro-i Föld csúcson, és bizonyos államok a témára való tekintettel egy NGO-ra ruházták az addig kizárólagosan állami szerepnek tartott nemzetközi jogalkotói hatáskörüket - ami azonban nem foglalta magában a döntéshozói jogkört, hiszen a végleges döntés meghozatala, a nemzetközi kötelezettség vállalása továbbra is az államok jogköre maradt. A környezetvédelem a nem állami szereplők befolyásának olyan példája, ahol a tematizáláson csak nagyon ritkán tudnak túllépni az államok érdemi befolyásolásának szintjére, így befolyásuk megreked ezen a relatíve alacsony szinten.

A következő pontokban olyan területeket mutatok be, ahol a nem állami szereplők befolyása érzékelhetően növekszik. Nem minden területen azonos módon és mértékben, de minden esetben a múlt század második felében tapasztalt alacsony intenzitású befolyásolási képesség egy új minőségi szakaszba lépett valamilyen szempontból. Míg korábban a nem állami szereplők az állami kereteken belül próbálták érvényesíteni érdekeiket, majd később a transznacionális kapcsolatok erősödésével nemzetközi szinten is igyekeztek befolyásolni az államok vagy a nemzetközi szervezetek tevékenységét, egyik esetben sem kérdőjelezték meg az államok létét. Befolyásolási tevékenységük tárgya volt maga az állam, esetenként az államokkal közösen léptek fel az adott kérdés megválaszolásában. A 21. században azonban egyre több esetben figyelhetjük meg, hogy a nem állami szereplők tevékenysége növekvő eséllyel az államok jólétét, szuverenitását, esetenként létét kérdőjelezi meg, illetve veszélyezteti. Tevékenységüket már az államok ellenében, nem ritkán az államokat helyettesítve határozzák meg. Ez egy olyan új típusú viszonyrendszert eredményez, ami érdemben befolyásolhatja a nemzetközi rendszer működését, mivel a kooperatív cselekvési stratégiával szemben a kompetitív stratégia kap növekvő szerepet, és jól érzékelhetően erősödik a konfrontatív megközelítés is. Alább a következő területeket emeljük ki:

1. emberi jogok - kooperatív

2. gazdasági- és pénzügyi kapcsolatok - kompetitív

3. erőszak monopóliuma - konfrontatív 


\subsubsection{Emberi jogok}

Az emberi jogok védelme az előzőekben említettekhez képest is talán az egyik legmarkánsabb területe a civil szféra részvételének a transznacionális kapcsolatokban. Dominánsan a nem állami szereplők befolyása növekedésének kooperatív modelljét mutatja. $^{41}$ A nemzetközi- és még inkább a transznacionális kapcsolatokat jogi megközelítésben Grotius óta egyfajta társadalmi kapcsolatrendszernek tekinthetjük (Lord 2004), ami teret enged az elemzés azon aspektusának, hogy hogyan képesek alakítani a nem állami szereplők az államok magatartását. Minél inkább a társadalom szövetét érintő kérdésről van szó, mint amilyen az emberi jogok érvényesülése, annál életszerübb ez a megközelítés. Legföképp az NGO-k vesznek részt ebben a tevékenységben. Alston (2005) helyesen mutat rá arra, hogy érdemi változás megy végbe ezen a területen is, mivel az NGO-k mellett más nem állami szereplök vonják magukra az emberi jogok kérdésével foglalkozó szakértők figyelmét: a transznacionális vállalatok, egyházak, szakszervezetek, emberi jogi csoportok és bizonyos nemzetközi szervezetek növekvő szerepet játszanak az emberi jogok specifikus típusainak érvényre juttatásában.

Az emberi jogok kérdésével foglalkozó nem állami szereplők a téma napirendre kerülésével párhuzamosan a második világháború után váltak a nemzetközi élet mind fontosabb szereplőivé. Első kiemelkedő és jól dokumentált eredményük maguknak az emberi jogoknak az ENSZ Alapokmányában való megjelenítéséért történt lobbizásuk 1945-ben, valamint az Emberi Jogok Egyetemes Nyilatkozatának megalkotásában való tevőleges szerepük volt. Maga az ENSZ Alapokmány az NGO-kat (nem kormányzati szervezet) nevesíti, mivel különbséget kellett tenni a kormányközi ügynökségekkel való együttmüködés és a nemzetközi nem kormányzati szervezetekkel való együttmüködés között. Az NGO-nak - mint korábban elemeztük - ezzel együtt sincs általánosan elfogadott definíciója, és más-más körülmények között eltérő lehet az értelmezése. 1946-ban az ENSZ ECOSOC konzultatív státuszt adott bizonyos nem állami szereplőknek. Ezt tekinthetjük az első intézményes lépésnek, amikortól már nem csak a tematizálásban, az emberi jogok megsértőinek beazonosításában és számonkérésében, a lobbizásban, hanem a jogalkotás folyamatában, bizonyos mértékig az emberi jogok nemzetközi védelmét biztosítani hivatott intézmények kialakításában is szerepet kaptak.

\footnotetext{
${ }^{41}$ Természetesen minden területen, így az emberi jogok esetében is találunk példát a másik két stratégiai megközelítésre. Ezen a területen például az emberi jogok tiszteletben tartása kikényszeríthetőségének nemzetközi szabályozása esetén találkozhatunk kompetitív vagy konfrontatív magatartással.
} 
Két évvel később újabb jelentős sikert könyvelhettek el az emberi jogokért küzdő nem állami szereplők, hiszen a jogok védelmét megalapozó intézményi fejlődést, az Emberi Jogok Egyetemes Nyilatkozatát sikerült elfogadtatniuk. (Arts 2004) Ahogyan Korey (1998) az NGO-kra vonatkoztatva megfogalmazza, tevékenységük egyik kiemelkedő eredménye, hogy olyan jelentős, a részes államokra nézve kötelező erejű konvenció kidolgozásában tudtak részt vállalni, mint a Polgári és Politikai Jogok Nemzetközi Egyezségokmánya és a Gazdasági, Szociális és Kulturális Jogok Nemzetközi Egyezségokmánya 1966-ban.

Az emberi jogok védelme érdekében folytatott küzdelem óriási lépést jelentett az 1970es 1980-as években - növelve ezáltal a nem állami szereplők tevékenységének elfogadottságát. Több országban a külpolitika szerves részévé vált ez a célkitüzés. Ennek egyik - talán legfontosabb, metateoretikus - oka, hogy elmozdulás történt az emberi jogok és a humanitárius jog viszonyában. Az 1970-es évekig a kettő élesen elkülönült a függetlenségi mozgalmak által meghatározott nemzetközi jogi térben. A nyolcvanas évekre az önmeghatározás formája jellemzően a fegyveres konfliktusról a politikai mozgalmak irányába tolódott el, a humanitárius jog és az emberi jogok értelmezése közeledett egymáshoz, több teret engedve olyan kérdéseknek mint a munkához való jog, a környezetvédelem vagy az emberi jogok új generációja. (Alston 2005) A hidegháború ideje alatt azonban ez a folyamat nem tudott kiteljesedni, mivel a két szembenálló tömb más-más jogok univerzális elismertetéséért küzdött. A keleti blokk országai minden nemzetközi fórumon a gazdasági és kollektív jogokat helyezték előtérbe, míg a nyugati blokk országai a polgári, politikai és egyéni jogok elfogadtatásáért küzdöttek. A hidegháború évtizedeiben az emberi jogokkal foglalkozó nemzetközi nem kormányzati szervezetek száma és aktivitása is folyamatosan nőtt. Csak 1983 és 1993 között megduplázódott a számuk. (Cakmak 2004) A hidegháború végét követően a nyugati értékrend győzelme ezen a területen is érzékeltette hatását. Az egyén jogai, az emberi jogok kerültek előtérbe a nemzetközi fórumokon. Ennek egyik markáns megnyilvánulása az 1993-ban Bécsben megrendezett Második Emberi Jogi Világkonferencia, amelyen több mint 1500 nem kormányzati szervezet képviseltette magát. (Steiner - Alston 1996) Több NGO képviselő vett részt a konferencián (3600), mint a 171 résztvevő országból érkező kormányzati képviselő (2100). (Martens 2000) Az emberi jogok területén tevékenykedő nem állami szereplők közül legismertebb az Amnesty International, amely ,az emberi jogok elismertetéséért küzd. Kutatásokat végez és akciókat szervez, s segítségükkel igyekszik megelőzni és megakadályozni a 
fizikai és szellemi integritáshoz, a lelkiismeret és szólás szabadságához, valamint a diszkrimináció-mentes élethez való jogok súlyos megsértéseit. Kormányoktól, egyházaktól, ideológiáktól és gazdasági érdekektől független szervezet. Kiterjedt tag- és támogatói hálózata van. ${ }^{42}$ Felmérések szerint öt kontinensen több mint 150 országban 1,8 millió taggal vagy támogatóval bír. Az Amnesty International-nak több pénze és több féle forrása van, mint az ENSZ Emberi Jogi Központjának.

Az NGO-k tevékenysége az állami szereplök munkájának támogatásában, egyes országokban a kérdés napirenden tartásában illetve a vállalt kötelezettségek számonkérésében, vagy éppen a kötelezettségvállalásra irányuló nyomásgyakorlásban testesül meg. Perkins (2005) az emberkereskedelem elleni küzdelem példáján mutatja be azt a három stratégiát, amivel a nem állami szereplők érdemi befolyást képesek gyakorolni, nevezetesen: a) a közvélemény figyelmének felkeltése, a tudatos tenni akarás előmozdítása; b) a kormányzati és nem kormányzati szereplők közötti együttmüködés segítése; valamint c) a témával foglalkozó NGO-k képességeinek fejlesztése. Amint arról az előző alfejezetben szó volt, a képességek változása - ebben az esetben növekedése - jelentős mértékben befolyásolja a nem állami szereplők érdekérvényesítési lehetőségét. A nem állami szereplők úgy is sikeresen tudnak fellépni az adott kérdésben, ha az államokat illetve nemzetközi szervezeteket abba az irányba tudják befolyásolni, hogy jogilag kötelező megállapodásokat, nemzetközi szerződéseket kössenek. Ebben az esetben is hozzájárulnak az emberi jogok érvényesítéséhez, mert a kötelező erejü szerződések számonkérése, az abban foglaltak kikényszerítése már könnyebb feladat. Az államokkal való együttmüködés jellemzően konstruktív hozzáálláson, közös célok megfogalmazásán alapul. Fontos ugyanakkor különbséget tenni az egy témával foglalkozó nem állami szereplők és a különböző témákkal foglalkozó, de valamilyen szempont alapján hálózatba szerveződő szereplők között. Előbbiek specifikus tudásuk, az adott témában kivívott tudományos vagy morális státusuk alapján tudnak befolyásoló tényezőként fellépni. Szakosodásukból adódóan azonban csak a szüken értelmezett érintettekre képesek befolyást gyakorolni. A hálózatok ezzel szemben nem annyira tagjaik külön-külön meglévő érdekérvényesítési képességére vagy szakmai tudására, mint inkább a tagok összességének erejére építenek. A hálózat kiterjedtsége és diverzitása lehetővé teszi, hogy a társadalom

\footnotetext{
${ }^{42} \mathrm{http} / / /$ www.amnesty.hu/content.php?oldal1=1, letöltve 2012. január 16.
} 
jelentős részét képviseljék, valamint a döntéshozók relatíve nagy számát elérjék. (Lord 2004)

A nem állami szereplők tevékenysége azért is jelentős, mert az emberi jogok kérdése az államközi kapcsolatok egyik problémás területe. Azok imént említett számonkérése, netán kikényszerítése a másik állam belügyeibe való beavatkozás határmezsgyéjén mozog, ezért azt csak különös körültekintéssel tematizálják az egyes kormányok. ${ }^{43} \mathrm{~A}$ nem állami szereplők ugyanakkor pontosan azzal a tematizálási hatalommal (,discursive power”, Arts 2004, p. 26.) rendelkeznek, amely lehetővé teszi, hogy az emberi jogok kérdését a belügyek kategóriájából átemeljék a világtársadalom ügyeinek kategóriájába. A figyelemfelhívó kampányok, az emberi jogi atrocitásokat elkövetők „megnevezése és megszégyenítése” a kommunikáció globalizálódásával és a nemzetközi média mozgósító erejének növekedésével egyre hatékonyabban tudják betölteni az államok által hagyott ürt. Mára szinte minimálisra zsugorodott azon földrajzi területek nagysága, ahol a szuverenitást gyakorló állam teljes mértékben ki tudja zárni a külső kommunikációs csatornákat, és ezáltal függetleníteni tudja magát ezektől a nyomás gyakorló eszközöktől. Ezen felül azon országok száma is folyamatosan csökken, amelyek nem engednek külföldi nem állami szereplöket tevékenykedni a területükön. Márpedig a fent említett, közvetlen befolyásolásra korlátozott tevékenységeken túl, amelyeknek önmagukban a célzott ország cselekvését alakító, döntéseinek kimenetelét módosító hatása van, a nem állami szereplők egyre több esetben aktív végrehajtóivá válnak az emberi jogok védelmét célzó lépéseknek a célország területén. Elvégeznek olyan feladatokat, amelyeket a nemzetközi közösség más tagjai nem tudnak, vagy nem akarnak megtenni. Az érintett személyek biztonságának garantálóivá, segélyek célba juttatóivá és elosztóivá, a segély-jogosultság meghatározóivá válnak. Sok esetben más államok vagy nemzetközi szervezetek nevében eljárva de facto korlátozzák a fogadó állam saját állampolgárai feletti szuverenitását. Tevékenységük a nemzetközi közösség hallgatólagos vagy tevőleges támogatásától függ. Befolyásuk relatív növekedése a fogadó állammal szemben tehát nem önmagától való, mások cselekedeteitől függ.

\footnotetext{
43 Jó példája ennek a 2008-as olimpiai játékokon való részvétel esetleges bojkottja körül kialakult polémia a tibeti emberi jogi helyzet miatt, ami ugyan csak áttételes hatással lett volna az érintett országok kétoldalú kapcsolataira, mégis komoly problémát okozott az egyes kormányoknak. A nem állami szereplők ugyanakkor az emberi jogok kérdésének folyamatos napirenden tartásával, rendszeres jelentések készítésével bármely országról véleményt formálhatnak, amelyen keresztül egyszerre befolyásolhatják az adott ország belső közvéleményét és nemzetközi megítélését.
} 
Az ENSZ az a nemzetközi szervezet, amely az emberi jogok kérdéseiben a legintézményesítettebb formában vonja be a nem állami szereplöket a jogalkotás folyamatába. A viták során kifejthetik véleményüket, értékelhetik a meglévő javaslatokat, vagy új javaslattal állhatnak elő. Mind több bizottság vonja be azokat munkájába: pl. a Gazdasági, Szociális és Kulturális Jogok Bizottsága vagy a Gyermekek Jogainak Bizottsága.

Az ENSZ-hez hasonlóan regionális szervezetek is együttmüködnek bizonyos nem állami szereplőkkel. Az Európa Tanács eljárásrendjébe ugyancsak bekerült az együttmüködés szabályozása, ami azért különösen fontos, mert az ET tekinthető talán a leghatékonyabb intézménynek az emberi jogok védelme területén.

Külön vizsgálatra érdemes az Európai Unió együttműködése a nem állami szereplőkkel az emberi jogok területén. Nagyon jelentős pénzügyi támogatást nyújt az emberi jogok érvényesítése és a demokrácia terjesztése érdekében tevékenykedő szervezeteknek. A különböző NGO-k az Unió legfontosabb partnerei közé tartoznak a fejlesztéspolitikában, a humanitárius tevékenység helyszínen történő megvalósításában. Az EU bevonja a nem állami szereplőket saját jogalkotási folyamatába, valamint támogatja pozíciójuk erősítését a nemzetközi szervezetekben és harmadik országokban is.

Folyamatában vizsgálva az emberi jogok érvényesítésének kérdését, egyértelmüen megállapítható, hogy a korábban a nemzeti szuverenitás kizárólagos fennhatósága alá tartozó téma előbb a nemzetközi szervezetek napirendjén jelent meg, majd egyre nagyobb mértékben kerül a nem állami szereplők befolyása alá. Az első fázis az államok önkéntes lépése: saját szuverenitásuk részleges átruházása az általuk létrehozott és saját szavazatuk révén irányított nemzetközi szervezetekre. A második fázis azonban már sokkal inkább kényszer: a nem állami szereplők „,beavatkozása belügyeikbe”. Természetesen utóbbit az államok korlátozhatják, de kérdés, hogy korlátozási képességük technikai (trasznacionális kommunikáció), morális (globális közvélemény) és jogi (nemzetközi egyezmények) értelemben valóban létezik-e, vagy egyre inkább csak a korlátozás illúziója marad. Keck és Sikkink elemzése alátámasztja, hogy „az emberi jogok nemzetközi védelmének doktrinája a szuverenitás hagyományos értelmezésének erős kritikája, és az emberi jogokat érintő jelenlegi jogi és külpolitikai gyakorlat megmutatja, hogyan változott a szuverenitás érvényességi körének megítélése.” (Keck - Sikkink 1998, p. 79) 
A nem állami szereplők tevékenységét ezen a területen nehéz kimerítően felsorolni, illetve hiánytalanul kategorizálni. Arts, Cook, Korey és Risse kategorizálását alapul véve és kiegészítve az alábbi kilenc kategóriát különböztetjük meg (Arts 2003, Cook 1996, Korey 1998, Risse 2000):

- Kampányok: a nemzetközi közvélemény és az államok figyelmének felkeltése és ráirányítása az emberi jogok megsértésére

- Adatgyüjtés: a nemzetközi közvélemény és a kormányok részére hiteles információ szolgáltatása az emberi jogi helyzetről és jogsértésekről

- Normaalkotás: nemzetközileg elfogadott emberi jogi normák meghatározása, illetve abban való közreműködés

- Tematizálás: a kérdés napirenden tartása és a politikai döntéshozatali folyamatokba való becsatornázása nemzeti vagy nemzetközi szinten

- Nyomásgyakorlás: a nemzetközi közvélemény nyomásának biztosítása és fenntartása a kormányok tevékenységének befolyásolása érdekében

- Jogalkotás: az emberi jogok védelmét és számonkérhetőségét biztosító jogszabályok megalkotásában, megszövegezésében történő szakértői részvétel

- Segélyek célba juttatása: az emberi jogok megsértését elszenvedők részére más nemzetközi vagy transznacionális szereplők által biztosított segélyek eljuttatása

- Terepmunka: az emberi jogok érvényesülését segítő programok kidolgozása és megvalósítása a helyszínen

- Monitoring: az államok és más nem állami szereplök emberi jogi normáknak való megfelelésének figyelemmel követése és számonkérése.

Az eddig leírtak és a fenti felsorolás is azt a képet erősíti, hogy a nem állami szereplők kizárólag pozitív szerepet játszanak az emberi jogok területén. Ezt a képet feltétlenül árnyalni kell. A vonatkozó irodalom kevés szót ejt arról, hogy a nem állami szereplők az emberi jogok megsértői is bizonyos esetekben. Itt utalok vissza a definíció problematikája során tett általános érvényű megállapításra, amely szerint a nem állami szereplö besorolás nem jelent minőségi besorolást: tevékenységük lehet pozitív, avagy negatív. Utóbbira klasszikus példa a fegyveres felkelők csoportjai, a nemzeti felszabadítási mozgalmak, a terrorista szervezetek, és bizonyos esetekben a TNC-k is. Az emberi jogok megsértése miatt vizsgált nem állami szereplőkről kritikus képet fest Alston (2005) valamint Andreopoulus és mások (2006). Esettanulmányok mutatják azt is, hogy nem tisztázott a nem állami szereplők felelőssége az emberi jogok megsértése 
esetén. Az emberi jogi egyezmények aláírói államok, a kötelezettségek vállalói is tehát az államok. A nem állami szereplökre - és a különböző nemzetközi szervezetekre, illetve ügynökségekre - az emberi jogok érvényesülését biztosító nemzetközi kötelezettségek csak közvetett módon, az államokon keresztül, az államok akaratától függően vonatkoznak.

A jogalkotási folyamatban részt vevő NGO-k növekvő száma és befolyása egyszersmind felveti e szervezetek legitimációjának és elszámoltathatóságának kérdését is az emberi jogok területén. Jelenleg nincsenek meg sem a nem állami szereplök teljesítményének méréséhez szükséges feltételek, sem azok a mutatók, amelyek segítségével értelmezni lehet e szereplők által képviselt érintettek körét. A globális társadalom, és az azt jelentősen befolyásoló globális kommunikációs szereplők hatására a nem állami szereplők mind több fórumra kapnak meghívást vagy részvételi lehetőséget. Ugyanakkor nem alakult ki az a mechanizmus, amelynek segítségével számon kérhetők, szankcionálhatók lennének. Mivel nem tisztázott a képviseltek köre, nincs olyan sem, aki meg tudná vonni a képviselet jogát. Mivel legtöbb esetben ad hoc alapon történik a kiválasztás, nincsen szabályozás vagy akár csak útmutatás, amin változtatni lehet. (Lord 2004)

Végül fontos visszautalni arra a visszásságra is, hogy a nem kormányzati szereplők egyre nagyobb részvétele ellenére (legyen szó egy probléma tematizálásáról vagy konkrét egyezmény szövegezéséről) a végeredményként megszülető kötelező vagy nem kötelező erejü nemzetközi egyezmények továbbra is csak az abban részes államokra vonatkoznak. A nem állami szereplők valójában kockázatvállalás nélkül vesznek részt a folyamatban, mivel semmilyen értelemben sem vonhatóak felelősségre. Továbbra is az állami szereplők felelőssége annak meghatározása, hogy mely érdekek képviseletét megjelenítő nem állami szereplőket engednek a tárgyalóasztalhoz. Az államok, mint a nemzetközi kapcsolatok korábban kizárólagosnak tekintett szereplői azonban nem engedhetik meg maguknak, hogy ne vonják be azokat a jogalkotás folyamatába az emberi jogok területén, amely korábban belügynek számított. Szuverenitásuk részben megkérdőjeleződik azáltal, hogy nem hagyhatják figyelmen kívül a civil társadalom érdekeit megjelenítő nem kormányzati szervezeteket - ha azok igazolhatóan és legalább részben igazolható módon reprezentatívan képviselik a civil társadalmat. A nem állami szereplők aktivitása ezen a területen mind mértékét, mind minőségét tekintve jelentősen megnőtt az elmúlt évtizedekben. Amint fentebb ismertettem, folyamatosan bővül tevékenységük köre, és befolyásukat már nemcsak közvetlenül az államok irányába 
gyakorolják, hanem nemzetközi szervezetekkel együttmüködve, vagy más nem állami szereplök mozgósításán keresztül multiplikálva azt. Ez hatványozottan növeli érdekérvényesítő képességüket a nemzetközi, illetve transznacionális erőtérben.

\subsubsection{Globális gazdasági folyamatok}

A gazdasági folyamatok, illetve azok szabályozása az állami és a nem állami szereplők viszonyának speciális szegmensét képezik. A nem állami szereplők ezen a területen egyre nagyobb mértékben jelennek meg kompetitív szerepben az államokkal szemben, sőt bizonyos esetekben a konfrontatív viszony is megfigyelhető. Ez azért érdemel kiemelt figyelmet, mert a hatalom összetevői között a gazdasági hatalom növekvő jelentőségre tesz szert a 21. században.

Korábban Nye osztályozását követve láttuk, hogy a gazdasági hatalom hogyan viszonyul a katonai hatalomhoz vagy a vonzás hatalmához. Gelb (2010) még tovább megy, amikor sorrendben legfontosabbnak a gazdasági erőt nevezi, és csak a második helyen említi a katonai képességek megőrzésének szükségességét. Véleménye szerint a 21. században a GDP lesz a hívó szó és a vezérmotívum a nemzetközi kapcsolatokban. A nem állami szereplők esetében természetesen nem értelmezhető a GDP fogalma, de gyakori összehasonlítási alap például az államok GDP-je és a vállalatok forgalma. „A növekvő vállalati hatalom, a javak és tulajdon koncentrációja, a globalizáció, a politikai aktivitás fokozódása és a nemzetközi hálózatok fejlődése a hatalom és képességek elmozdulását eredményezik a nem állami szereplök javára.” (Andreopoulus et al. 2006, p. 333) A transznacionális vállalatok jelentős gazdasági erőt koncentrálnak, és az államokkal szemben sok esetben egyenrangú félként lépnek fel. Ismert példa, hogy a tizenöt országban jelen lévő Wal-Mart amerikai vállalat forgalmát az államok GDPjével összevetve 25. lenne a világ rangsorban. Huszonöt amerikai vállalat kerülne be az országok összesített rangsorába - megelőzve legalább egy országot. Magyarországot például hét amerikai vállalat előzte volna meg 2010-ben ebben a rangsorban. (Trivett 2011) Több esetben előfordul, hogy egy adott ország területén egy saját GDP-jénél összességében nagyobb forgalommal bíró vállalat tevékenykedik, vagyis gazdasági értelemben az állam egy nálánál nagyobb gazdasági erővel bíró nem állami szereplővel folytat érdekérvényesítési küzdelmet. Fontos természetesen itt visszautalni arra, hogy a birtokolt hatalom nem minden esetben váltható át a befolyás érvényesítésén keresztül a másik magatartásának alakítási képességévé. 
Szentes szerint ,[a] gazdasági viszonyokat az alábbi változatok szerint különböztetjük meg:

1. a gazdasági (illetve gazdaságilag hasznosítható természeti) erőforrások és fejlesztési eszközök, illetve kapacitások feletti tulajdon és birtoklás (nemzetköziesedő) viszonyai,

2. a (nemzetközi) gazdasági vonatkozású döntéshozatal, végrehajtás és ellenőrzés „vertikális” irányú viszonyai, vagyis a (nemzetközi) gazdasági folyamatokon belüli aláés fölérendeltségi viszonyok,

3. a szakosodás és (nemzetközi) munkamegosztás ,horizontális” viszonyai, valamint 4. a (nemzetközi) jövedelemelosztás és -újraelosztás túlnyomórészt az előbbiek által meghatározott viszonyai.” (Szentes 2005, p. 30)

A gazdasági folyamatok befolyásolási képessége szempontjából egy nagyon fontos fejlődési folyamatnak lehetünk tanúi a 20. század utolsó harmadától kezdődően. Szentes szerint „a világgazdaság történetének - ha nem is minden vonatkozásban, de sok tekintetben - így egy újabb, ötödik korszaka kezdődött az 1973-74-es válságtól számítva." (Szentes 2005, p. 27) Ezt 1990-től a felgyorsult globalizáció kora követi. A piacok fontosságának növekedésével a piaci szereplök jelentősége is megnövekedett. A globalizáció során a piaci szereplők között mind nagyobb számban jelentek meg nem állami szereplők, és ezzel párhuzamosan az állami szereplők súlya relatív értelemben csökkent. (Della Porta - Tarrow 2004) A világgazdaság globalizációjának folyamata szinte törvényszerüen kikényszerítette, hogy a gazdasági szereplök az állami határokat figyelmen kívül hagyva tevékenységüket transznacionális szintre emeljék. Ezen a területen a „nem állami szereplők” megközelítés helyett kifejezőbb a „nem egy államhoz kötődő" szereplők meghatározás.

A világgazdaság ezen korszakát jellemző problémák, mint a stagfláció, ${ }^{44}$ az olaj- és adósságválságok, a súlyosbodó környezetszennyezési és ökológiai viszonyok, vagy az aranydeviza rendszer, mint nemzetközi monetáris struktúra felbomlása új folyamatoknak nyitottak teret. Sok OECD ország maga ösztönözte vállalatait, hogy a transznacionális müködési keretek adta lehetőségeket kihasználva külföldre vigyék tevékenységük kisebb vagy nagyobb részét. A „pénzügyi forradalom” névvel is illetett 1970-es években a kommunikációs és információs technológia új eredményei megnövelték a fejlett országok és azok vállalatainak előnyét, kiszélesítették az addigi

\footnotetext{
${ }^{44}$ Stagflációnak nevezik a 1960-as években elöször jelentkezett infláció és munkanélküliség együttes növekedésének jelenségét.
} 
tranzakciós kereteket földrajzi és időbeli értelemben. Az 1980-as években azután az adósságválságok számos más országot kényszerítettek arra, hogy elfogadják és alkalmazzák a neoliberális gazdaságpolitikai elveket, azaz megnyissák piacaikat, privatizációt hajtsanak végre, és beengedjék a külföldi nem állami szereplőket.

Ezt a periódust vizsgálva a legtöbb elemzés az MNC-k és TNC-k szerepére koncentrált, és elsősorban a kereskedelmi korlátozások és a befektetési lehetőségek szabályozása szempontjából vizsgálta az államok és a nem állami szereplők közötti viszonyt. Meg kell különböztetnünk a multinacionális és a transznacionális vállalatokat, ${ }^{45}$ mert azok szerepe az állami szereplők magatartásának formálásában alapvetően eltérő. A világon jelenleg több mint egy millió MNC és TNC müködik. Az 1970-es években - a nemzetközi gazdasági kapcsolatok alakítása szempontjából - az államok legfőbb félelme az volt, hogy a multinacionális vállalatok egyes kormányok kinyújtott karjaként viselkednek majd, elősegítve az adott ország érdekeinek érvényesülését. Ma sokkal inkább azt tekintik kihívásnak a kormányok, hogy hogyan tudnak megfelelő intézményi, gazdasági, politikai és társadalmi feltételeket teremteni ahhoz, hogy a transznacionális vállalatok hazai bázisává válhassanak, vagy ellensúlyozzák a transznacionális vállalat letelepedése okozta gazdasági és pénzügyi torzulásokat.

Az államok mozgásterét - bizonyos értelemben szuverenitását - szűkíti az adóbevételek csökkenése, a foglalkoztatás változásából adódó negatív költségvetési változások, vagy az államok megítélésének romlása következtében megnövekvő adósságteher. A transznacionális vállalatok az első két esetben rendelkeznek bizonyos mértékü hatalommal az államokkal szemben. Az általuk fizetett adó az államok felettük gyakorolt szuverenitásának egyértelmü jele. Csakhogy a globalizáció következtében a vállalatok mind több lehetőséggel rendelkeznek arra, hogy kiválasszák, mely államban kívánnak adót fizetni, illetve egy bizonyos méret felett kellően erős tárgyalási pozícióval rendelkeznek az adófizetés - vagy mentesség - feltételeinek meghatározásához. Az országoknak ebben az esetben egyre inkább csak a „szabályozás illúziója” (Mathews 1997, p. 50) marad, mivel nemzeti szabályaik megalkotásakor figyelembe kell venniük a világgazdaságban kialakult feltételeket annak érdekében,

\footnotetext{
45 Multinacionális vállalat: olyan vegyes tulajdonú vállalat, amelynek részvényesei különböző állampolgárságú tulajdonosok, a vállalat müködésében viszont ez a tulajdonosi elkülönülés és az ahhoz kapcsolódó illetékességi elhatárolódás közvetlenül nem érvényesül, vagyis amelynek irányítása és üzletpolitikája az „egynemzetiségü” részvénytársaságokéhoz hasonlóan egységes és nyereségorientált. Transznacionális vállalat: Azok a vállalatok, részvénytársaságok, illetve korporációk, amelyeknek nemcsak a müködése terjed ki - leányvállalataik és bedolgozó-szolgáltató partnereik révén - egyszerre több nemzetgazdaságra, hanem tőketulajdonuk is „,öbbnemzetiségü” (multinacionális), vagyis egynél több ország állampolgáraihoz, illetve jogi személyiségeihez tartozik. (Szentes 2005)
} 
hogy ne veszítsék el vonzerejüket, és ezen keresztül a tőkeberuházásokat valamint az azzal járó munkahelyeket.

Hasonló érdekérvényesítési képességre tettek szert a gazdasági nem állami szereplők a foglalkoztatás kérdésében játszott szerepük révén. Az államok költségvetési egyenlege szempontjából fontos, hogy a foglalkoztatás szintje minél magasabb legyen annak érdekében, hogy az adók és járulékok növekedésével és a szociális kiadások csökkenésével a költségvetés egyenlege javuljon. Az államok számára két út áll nyitva: folyamatos alkalmazkodással az üzleti élet szereplői számára kedvező környezetet teremtenek, vagy kompenzálják azokat, akik a nem állami szereplök döntéseinek legsúlyosabb kárvallottjai. (Glenn 2009) Mindkét út bizonyos értelemben kényszerpályát jelent. Glenn tanulmánya rámutat arra, hogy a fejlett országok jellemzően a szociális háló erősítésével válaszolnak, míg a fejlődőek kisebb-nagyobb strukturális reformokat igyekeznek végrehajtani. Akár így, akár úgy, az államok döntési szabadsága csökken.

A fentebb leírt esetekben a gazdasági szereplők ugyanakkor nem tudtak, vagy csak nagyon korlátozott mértékben, cselekedeteikkel olyan befolyást gyakorolni a gazdasági folyamatokra, illetve más gazdasági szereplökre, amelyek az államokra nézve érdemi hatást gyakoroltak volna. Egyrészt e vállalatok alapvető stratégiájának, tevékenységüknek minél több államban történő szétterítésének egyik eredménye épp az lett, hogy nem koncentrálódott kellő befolyásolási képesség egyetlen állammal szemben sem. Másrészt azt is megállapíthatjuk, hogy még azokban az országokban is, ahol egyegy nagy befolyással rendelkező nem állami szereplő képes az állammal szemben érvényesíteni érdekeit, ez a befolyás nem terjed túl az adott szereplő és az állam kapcsolatán. Nem hat más vállalatokra, illetve nem állami szereplőkre, vagy azoknak az államhoz viszonyított helyzetére, ahogyan nem hat az állam más funkcióinak ellátására vonatkozó képességére sem. Megjelenésük elsősorban a gazdasági erőforrások tulajdoni viszonyaiban hoz változást. Az alapvető hatalmi viszonyok nem változnak meg, ezek a nem állami szereplők csak az őket közvetlenül érintő kérdésekben képesek befolyásolni az államot.

A gazdasági folyamatokban a nem állami szereplők államokra gyakorolt befolyásának másik fontos területe az államok közötti tárgyalásokba történő bekapcsolódás. Mind gyakrabban kapnak szerepet konzultánsként, tanácsadóként. Esetenként helyet kapnak a tárgyalóasztalnál is. Míg a gazdasági szereplők képviselőinek szinte közvetlen bevonása egyes tárgyalásokba egyértelmű sikerként vált ismertté, számos példa jól mutatja a 
probléma nehézségeit: Mikor tekinthetők legitim érdek-képviselőnek? Az esetek többségében csak korlátozott számú nem állami szereplöt lehet bevonni az egyeztetési folyamatokba. Felvetődik tehát a kérdés, hogy a döntési folyamat hatékonyságának megőrzésével egy időben hogyan biztosítható a megfelelő nem állami képviselet. Még egy szinttel lejjebb kezdve az elemzést, az a kérdés merül fel, hogy a jelentkező szervezetek közül melyek tekinthetők reprezentatívnak, vagyis milyen elvek alapján ismerünk el egy nem állami szereplőt az adott érdekek képviselőjeként.

A nem állami szereplök részvétele a GATT uruguayi fordulóján, majd az OECD közvetlen külföldi tőkeberuházások szabályozási tevékenységében - amit a nemzetközi gazdasági viszonyok és a munkamegosztási viszonyok változása kényszerített ki nemcsak új befolyási területet jelentett, de a befolyásolási képesség új minőségét is, mivel a gazdasági viszonyok Szentes által meghatározott változatai közül a tulajdonviszonyokon túl a döntéshozatali és végrehajtási viszonyokra a korábbinál nagyobb hatást gyakoroltak. (Walter 2001) Utóbbi külön érdekessége, hogy a tárgyalásokon részt vevő országokon kívül a nem állami szereplök mind az egyezmény mellett, mind az ellen felsorakoztak. A gazdasági szereplők és a gazdasági érdekérvényesítésben jelentős szerepet játszó lobbi szervezetek álltak szemben a különböző nem gazdasági érdekeket képviselő NGO-kkal. Az elsősorban környezet- és fogyasztóvédelemmel foglalkozó NGO-k képessége arra, hogy a részt vevő államok belső ratifikációs folyamatának sikerét megkérdőjelezzék, illetve esetenként biztosan megakadályozzák, nagymértékben, de semmi esetre sem kizárólagosan, hozzájárult az egyeztetések eredménytelenségéhez. A liberalizáció folyamata bizonyosan a jövőben is az állami szereplők valamint a támogató és ellenző nem állami szereplők háromszögében fog zajlani, és az erőviszonyok változásától jelentősen függeni fog. A különböző nem állami szereplők megkerülhetetlensége várhatóan valamilyen mértékü és formájú bevonásukat fogja biztosítani, ami definíció szerint növelni fogja a szabályozás befolyásolásának képességét. Ez egyben azt is jelenti, hogy a TNC-k és az államok kétoldalú kölcsönhatásán túllépve a liberalizáció szabályozásának befolyásolásával az államok mozgásterét bizonyos mértékben korlátozni tudják gazdasági nem állami szereplők, és közvetett módon hatni képesek más nem állami szereplők helyzetét is befolyásolni. Ezzel együtt hangsúlyoznunk kell, hogy bár újabb területről beszélünk, és a nem állami szereplők már más nem állami szereplőkre is hatást gyakorolnak, a befolyásolási képesség növekedése ebben az esetben is csak az adott területre vonatkozik. 
A fenti példákon túlmutató egészen új korszak kezdetét jelentheti az államok mozgásterének közvetett korlátozása a nem állami szereplők irányában fennálló adósságtörlesztési kötelezettségük, illetve tőkevonzó képességük befolyásolása révén. A felgyorsult globalizáció korára jellemző gazdasági berendezkedésben a tőkemozgások befolyásolási képessége a gazdasági hatalom egyik legfontosabb összetevőjévé vált. Bizonyos értelemben mások tőkemozgásra vonatkozó döntései manipulálásának képessége nagyobb befolyást biztosít egy-egy szereplővel szemben, mint a tőke birtoklása maga. A 2008-ban kirobbant gazdasági- és pénzügyi válság is rávilágított arra, hogy a nyitott, globális pénzügyi piacokon a pénzügyi befektetők befolyása jelentősen megnőtt. A válság idején a befektetők kockázatkerülőbbek. A befektetések elmaradása, vagy a tőke kivonása rávilágít arra, hogy mekkora súllyal esik latba a tőkevonzó, illetve -megtartó képesség. Glenn felhívja a figyelmet arra, hogy a globalizáció következtében megnövekedett mobilitás egyben az elvándorlás képességét is fokozza, vagyis mind több esetben jelent hatalmat a kivonulással való fenyegetés, a „lábbal történő szavazás”. (Glenn 2009, p. 28)

Izland példája megmutatta, hogy egy ország gazdasága - extrapolálva: léte - függhet a pénzügyi nem állami szereplők döntéseitől. A piaci szereplők bizalmának megingása a bankszektor egyes szereplői, majd egésze irányába az állam részéről a piaci kereskedés felfüggesztését, illetve a bankok részleges felvásárlását tette szükségessé. A megtett kényszerintézkedések ellenére a korona árfolyama felére esett, az ország gazdasági teljesítménye jelentősen romlott.

Az Egyesült Államok esetében 2011-ben a Standard \& Poor’s az adminisztráció és a kongresszus között létrejött költségvetési megállapodást elégtelennek ítélve „AAA”-ról - első ízben - „AA+”-ra minősítette le a világ legnagyobb gazdasági hatalmát. A leértékelés a hitelminősítő azon véleményét tükrözte, hogy „az amerikai döntéshozatal és politikai intézmények hatékonysága, stabilitása és kiszámíthatósága meggyengült a pénzügyi és gazdasági kihívások idején.” (Appelbaum - Dash 2011) Bár az amerikai államkötvények a legbiztonságosabb befektetésnek voltak tekinthetők, a leértékelés hírére jelentős mértékben megingott az árfolyamuk. Az Egyesült Államok évi 250 milliárd dollárnyi kamatfizetési kötelezettsége mellett az államkötvény hozamok és a piaci hitelkamatok kismértékű növekedése is több tíz milliárd dolláros kiadásnövekedést jelentett volna, ami az állami kiadások lefaragását, vagyis az állam mozgásterének, végső soron befolyásolási képességének csökkenését jelenti. A fenti példa ugyan még azt mutatta, hogy egy hitelminősítő döntése nem okozott tartós 
változást a piaci szereplők magatartásában, de kettő vagy mindhárom intézet egyirányú lépése már érzékelhető befolyást jelenthetett volna.

Magyarország példája azt mutatta, hogy az ország adósságállományának első leminősítésére (Moody’s, 2011. november 24.) a piacok hirtelen bizalomvesztéssel reagáltak. A forint euróval szembeni árfolyama 2 százalékkal leértékelődött - átlépve a 316 HUF/EUR szintet (Forrás: MNB). A tíz éves lejáratú államkötvény hozamok 9,56 százalékra emelkedtek. Az árfolyam azonban egy nap után visszatért 310 HUF/EUR szint alá, sőt kis ingadozásokkal 300 HUF/EUR körül stabilizálódott egészen a következő leértékelésig. A kötvényhozamok szintén visszatértek a korábbi szint közelébe, de rögtön lassú emelkedésnek indultak. A második hitelminősítő, a Standard \& Poor's december végi döntése után már sem a forint árfolyama, sem a kötvényhozamok nem tértek vissza a korábbi szintre, sőt folyamatos növekedést produkáltak. Hasonlóan a korábbi esethez a forint közel 2 százalékot értékelődött le az euróval szemben, és sokáig nem mozdult felfelé. Az államkötvény hozamok megközelítették a 10 százalékot. A Fitch leminősítése - harmadikként - az általános megítélés szerint már nem váltott ki jelentős hatást, mivel egyrészt a piacok számítottak rá, másrészt a magyar kormány bejelentése az IMF-fel zajló tárgyalásokról való egyeztetések megkezdéséről pozitív irányba lökte a forintot - 316 HUF/EUR szintről 313 HUF/EUR-ra. Ugyancsak jelentős hatást váltott ki az eurózóna egészére a Standard \& Poor's kilenc euró övezeti ország leminősítésére vonatkozó 2012. január 13-i bejelentése.

A globalizált pénzügyi piacok és tőzsde müködési mechanizmusai miatt a hitelminősítő intézetek befolyása az államokkal szemben jelentős mértékben megnőtt. Az egyes országok besorolása az állampapír- és hitelpiacok áttételes hatásán keresztül olyan befolyást biztosít a hitelminősítő intézetek részére, amely megegyezik, illetve esetenként meg is haladja az államok képességét. A Standard \& Poor's, a Moody's és a Fitch a nemzetközi pénzpiacok olyan szereplői, akik állásfoglalásukkal közvetlenül mondanak ítéletet az államok felett hitelminősítési besorolásuk változtatásával. Lépéseik a többi piaci szereplő viselkedését befolyásolják, ami közvetve hat az államok hitelfelvételi és tőkevonzó képességére. A globális pénzpiacoknak köszönhetően egy ország besorolásának módosulása az államkötvények hozamában bekövetkező változáson keresztül az állam költségvetési mozgásterét olyan mértékben bővítheti vagy szükítheti, hogy az lényeges változásokat eredményezhet az államilag biztosított funkciók ellátásában. 
A hitelminősítő intézetek államokkal szembeni befolyásának jelentős mértékü növekedését felnagyítva mutatta meg a globális gazdasági és pénzügyi válság - ám azt általános érvényünek tekinthetjük. Mosley (2005) helyesen mutat rá arra, hogy az államok képessége relatív pozíciójuk erősítésére - legyen az a globalizációval szembeni specializáció, vagy a többi állammal való versengés - egyre inkább eltörpül a globális piacokat befolyásoló külső tényezők, az időszakos „mánia” vagy „pánik” mellett. Mindkettő nem állami szereplő tevékenységéhez kötődik: a pénzügyi piaci mánia kialakulása leggyakrabban a nem állami szereplők csorda effektus alapján követett magatartásának eredménye, míg a válság kirobbanásában legalább akkora szerepe volt a jelzálog alapú kötvények megbízhatósága túlértékelésének mint magának a pénzügyi konstrukció létrehozásának. Ugyanakkor a válság következményeinek kezelése az államok feladata maradt. A hitelminősítők, mint nem állami szereplők döntései a gazdasági szereplőket olyan pénzügypiaci lépések megtételére késztethetik, amelyek az állami szereplők szuverén döntési képességét korlátozzák, vagy azokat szükséges korrekciós lépések megtételére kényszerítik. Ezáltal az adott kormány esetenként rákényszerülhet arra, hogy valamely belső politikáján változtasson, szélsőséges esetben lemondjon valamely funkciójának ellátásáról - fizetési kötelezettségének teljesítése, közszolgáltatások ellátása, bérek vagy nyugdíjak folyósítása, stb. Ez a hatás már áttételeken keresztül ugyan, de - az állam más funkcióit érinti, vagyis a nem állami szereplőt olyan befolyásolási képességhez juttatja, ami túlmutat az általa kifejtett tevékenység határain. Ezek alapján megállapíthatjuk, hogy a nem állami szereplök legyen szó TNC-kről vagy pénzügyi szereplőkről - képesek sokszereplős globalizált rendszerekben az államokkal szemben közvetlenül, vagy a többi szereplő magatartásának befolyásolásán keresztül közvetetten olyan hatást gyakorolni, amelyet az államok nem tudnak ellensúlyozni.

\subsubsection{Az erōszak monopóliuma}

Harmadikként tekintsük át a hagyományosan az államok monopóliumának tekintett erőszak alkalmazásának jogát és képességét. „Nemzetközi erőszak-monopólium nem létezik. A nemzetközi rendszerekben az állam eröszak-monopóliumának a kialakulásával megszünik az anarchia, míg a nemzetközi rendszernek anarchikus felépítése van.” (Kiss J. 2003, p. 14) A nem állami szereplők képességének változásával ezen a területen is elmozdulás figyelhető meg. A nem állami szereplők korábban 
kizárólagosan elszenvedői voltak az államok cselekedeteinek. A nem állami szereplők által a fegyveres erő alkalmazása, vagy az azzal való fenyegetés, mások jogainak erővel történő korlátozása az államok jogával szembeni konfrontatív fellépést jelent. Az erőszak alkalmazásának jogáért való küzdelem konfrontatív, zéró összegü versengés. Az erőszak monopóliuma birtoklásának fogalmát, illetve elvesztésének folyamatát a biztonság koncepciójának változása tükrében kell megvizsgálnunk. Ezt követően tudjuk megállapítani, hogy az egyes aktorok hogyan viszonyulnak ehhez.

Általánosan elfogadott megállapításnak tekinthetjük, hogy a 21. században a biztonság már nem egyenlő a külső biztonsággal, és nem szükíthető le a katonai biztonságra. Olyan multidiszciplináris fogalommá vált, ami kiterjed a katonai biztonságon és szövetségi rendszereken túl egy ország belső (gazdasági, migrációs, stb.) stabilitására, társadalmi helyzetére (etnikai, vallási, kulturális, stb.), ugyanakkor a rá leselkedő terrorista vagy szeparatista veszélyek kezelésére vagy épp az adott földrajzi térséget érő környezeti kihívásokra. A realista elmélet a biztonság fogalmát is az állam léte szempontjából vizsgálja. Még ha tudomást is vesz nem állami szereplők (elsősorban terrorista szervezetek, illetve békemozgalmak) létezéséről, azokat vagy államok proxiszervezeteiként kezeli, és ezáltal visszavezeti a kérdést államok közötti konfrontációra, vagy államokra leselkedő veszélyforrásként értelmezve azokat az államok által teendő elsősorban katonai lépésekben gondolkodik. A liberális megközelítés már sokkal több figyelmet szentel a nemzetközi szervezeteknek és az NGO-knak. Figyelembe veszi azt is, hogy a biztonság fogalma a hatalom fogalmához hasonlóan többszintüvé vált. A biztonságpolitikában a hagyományosan meghatározónak tartott államok és nemzetközi szervezetek mellett megjelentek, illetve megerősödtek olyan nem állami szereplők, mint a magán biztonsági cégek, magánhadseregek, védelmi ipari vállalatok és a hozzájuk kötődő lobbi szervezetek, a békemozgalmak, a terrorista- és szeparatista szervezetek, egyes biztonságpolitikára szakosodott kutató intézetek, think-tankek, állami funkciókat átvállaló gazdasági társaságok, de bizonyos esetekben vallási közösségek is.

A liberális elmélet problémája azonban, hogy a nem állami szereplők tevékenységét alapvetően pozitívan értelmezi, és rózsaszín szemüvegen keresztül vizsgálja a nemzetközi biztonsághoz való hozzájárulásukat. Ezáltal az erőszak monopóliumának megszerzésére törekvő nem állami szereplők kérdését nem vizsgálja kellő kritikával. Az új középkor elmélet vizsgálja a nem állami szereplők legszélesebb körét a biztonság és az erőszak monopóliuma szempontjából. Rámutat arra, hogy az egyes szereplők céljai és eszközei milyen mértékben eltérőek lehetnek. Ez magában hordozza annak a 
szükségességét is, hogy a kölcsönhatások minőségét és mennyiségét is új megvilágításba helyezzük. Clarke (2000) államokra vonatkozó megállapításának általánosításával azt mondhatjuk, hogy a biztonság fogalmának vizsgálatakor a nemzetközi szereplőknek újra kell értékelniük azt, ahogyan magukról és az őket körülvevő nemzetközi rendszerről gondolkodnak.

Az erőszak állami monopóliumának sikertelen gyakorlása, a lakosság feletti hatékonytalan ellenőrzés idézi elő elsődlegesen a nem állami szereplők megjelenését ezen a területen. Függetlenül attól, hogy létrehozásukkor a különböző szervezetek milyen célokat követtek, ezek az erőszak alkalmazására épülő nem állami szereplők vagy Thompson kifejezésével élve ,virtuális rezsimek” (Thompson 2002, p. 507) a jelenleg fennálló állam-központú nemzetközi rendszer ellenében valósítják meg céljaikat. A Hamasz és a Hezbollah esetében kezdetben szociális indíttatású aktorokról beszélhetünk, a FARC már létrejöttekor is az állami ellenörzés ellen küzdő félkatonai szerezet volt, míg az Al-Káida globális terror szervezet létrehozását tüzte ki célul.

Az erőszak monopóliumának megtörésére, illetve megszerzésére törekvő nem állami szereplők megjelenésének és megerősödésének kiváltó oka lehet a szociális ellátórendszerek hiánya, vagy hiányos müködése. Ez leggyakrabban a szegény államok és a bukott államok esetében figyelhető meg - elsősorban helyi szinten, ami azután fokozatosan bővülhet és emelkedhet regionális vagy akár állami szintre. Olyan nem állami szereplők, mint a Hamasz a palesztin területeken, a Hezbollah Dél-Libanonban, a Maoisták Nepálban illetve India bizonyos területein azzal alapozták meg létüket és támogatottságukat évtizedekkel ezelőtt, hogy alapvető szociális és egészségügyi ellátást, oktatást és esetenként védelmet nyújtottak az arra rászoruló lakosságnak. Látható, hogy mindezen szervezetek létjogosultságának közös vonása, hogy az adott kormányok akaratlagos vagy tehetetlenségéből adódó tétlenségéből eredeztethető egyenlőtlenségek kiküszöbölésére, hiányosságok pótlására alapozzák bázisukat, majd ebből a tevékenységből később politikai tőkét kovácsoltak. Az, hogy ez a fejlődés később milyen irányba fordult, törvényes politizálássá vagy erőszakos kormányellenességgé vált, már az adott nem állami szereplők céljától és az érintett állam szuverenitásának megőrzésére irányuló képességétől függött.

Ugyanakkor általánosságban elmondható, hogy a nem állami szereplők egy speciális csoportját alkotó terrorista illetve szervezett bünözői csoportok céljai valamely „felsőbb ideológia” szolgálatában állnak, és azok megvalósítása érdekében ugyanazt az állami müködést másolják, amely ellen fel kívánnak lépni. Rendelkeznek „lakossággal”, 
tevékenységi „területtel” (virtuálissal vagy fizikaival), valamiféle „kormányzattal” és valamiféle „gazdasági erővel” akárcsak az államok. De ezek értelmezése és jelentősége eltér a klasszikus vesztfáliai állam esetében meghatározottól. Ezek a nem állami szereplők a korábban elemzettekhez hasonlóan a transznacionális térbe kilépve tettek szert jelentős relatív hatalomra. Hálózatok kialakításával, és egyre gyakrabban a média multiplikatív hatását meglovagolva igyekeznek elérni céljaikat. Tevékenységük irányulhat az állam tevékenységének megkérdőjelezésére, az állam hatalmának gyengítésére vagy az állami kontroll teljes megszüntetésére. Mindegyik esetben komoly veszélyt jelentenek a nemzetközi biztonságra. A velük szemben történő fellépés éppen transznacionális és virtuális jellegükből adódóan ugyanakkor több esetben visszahull az őket támogató vagy jelenlétüket felszámolni nem tudó illetve nem akaró államokra.

Megállapíthatjuk, hogy az állami erőszak monopólium megtörésére, illetve megszerzésére a terrorista, illetve szervezett bünözői csoportok törekednek elsődlegesen. Növekvő gazdasági erejük, és a rendelkezésükre álló eszközök folyamatos fejlődésének köszönhetően mind nagyobb mértékben képesek átvenni ezt az állami funkciót. A közlekedési és kommunikációs technika és infrastruktúra fejlődésével, a virtuális távolságok megszünésével a migráció folyamatosan erősödik, és kialakul egy transznacionális társadalmi tér, amelyben gyengül, avagy teljesen megszünik az egyén és a terület közötti kapocs. Ez a folyamat tovább erősíti a transznacionális nem állami szereplők befolyását az egyénekre az államokkal szemben. A gazdasági indíttatású migráció, ami megvalósítja Smith láthatatlan kéz elméletét a munkaerő tekintetében, megszünteti az egyén és a terület közötti kapcsolatot. (Guest 2011) Ugyanakkor az egyén és a terület közötti kapcsolat hiánya gyengíti az erőszak állami monopóliumát, és ezzel párhuzamosan erősíti egyes nem állami szereplők befolyását. 2050-re az előrejelzések szerint a migránsok száma eléri a 405 milliót. A legnagyobb befogadók az EU, az USA és Kína lehetnek. (IOM 2010)

$\mathrm{Az}$ államokkal szemben az erőszak gyakorlásának céljával létrejött nem állami szereplőktől meg kell különböztetni az államok által kezdeményezett hatalommegosztást. Az állami erőszak monopólium nem állami szereplők kezébe adásának példája a hadsereg tevékenységének szándékos kiszervezése, vagyis az államok részéről a nem állami szereplők kapacitásainak tudatos bevonása. Történelmi visszatekintésben megállapítható, hogy a napóleoni háborúk voltak az első a társadalom egészét érintő összeütközések. (Clausewitz 1976) Korábban vállalkozások, gyakran kereskedelmi vállalkozások, illetve személyek, szervezetek biztosították a szükséges haderőt 
haszonszerzés céljából. Ezek a konfliktusok az állam részéről csak hozzájárulást, együttmüködést igényeltek, finanszírozást nem. Az adózás szintjének emelkedésével, többek között a jövedelemadó bevezetésével vált lehetségessé, és mind nagyobb mértékben elvárássá az állam által biztosított hadsereg. Ez Európában a 18. század második felére tehető, vagyis a modern nemzetállam időszakára.

A 20. század második felében ugyanakkor már a - Martin Shaw szavaival élve - ,postmilitary societies” időszakát éljük, amikor a hadsereg és tevékenysége ismét nem játszik központi szerepet a társadalom egészének életében. (Shaw 1991) Ennek jellegzetes mutatója a kötelező sorkatonai szolgálat megszünése előbb a nyugati, majd a keleti társadalmakban is. A professzionális „,zsoldos” hadseregek egyre több ország esetében nagyobb részt a tüzoltósághoz vagy a katasztrófavédelemhez hasonló közfeladatokat és csak kisebb részt klasszikus harcászati feladatokat látnak el. A biztonság fogalma a hidegháborút követően átértékelődött, és a terrorizmus relatív megerősödése következtében sem kapta vissza korábbi megkerülhetetlen jellegét. Ebből következik, hogy az állam minden katonai beavatkozást igénylő esetben egyre nagyobb mértékben veszi figyelembe a belpolitikai, a hatékonysági és a költségvetési megfontolásokat. Bizonyos esetekben az államok önszántukból szerveznek ki bizonyos feladatokat. Az erőszak monopóliuma megszűnésének és az erőszak alkalmazás képességének nem állami szereplők kezébe adásának ékes példái a magán biztonsági cégek, amelyeknek az államok részben vagy egészben kiszerződik ezt a tevékenységet. Ezek száma folyamatosan nő: Oroszországban több mint tízezer, de említhetjük Dél-Afrikát, ahol a személyi testőrök száma meghaladja az állami rendőrség személyi állományát. (Josselin - Wallace 2001, p. 199) Azokban az országokban, ahol az állam nem képes ellátni a biztonság szavatolása feladatát, növekvő számban jelennek meg ilyen magán cégek. Egyes szerzők egyenesen azt vetítik előre, hogy a magán biztonsági cégek teljes mértékben átveszik ezt az állami feladatot. (Van Creveld 1991, p. 138) Mások a KeletIndiai Társaság történelmi példájából és a nagyvállalatok gazdasági erejéből kiindulva azt prognosztizálják, hogy a vállalatok saját biztonságuk érdekében létrehozott biztonsági szolgáltatásai az államok konkurenseivé válhatnak. (Barnet - Kavanagh 1994, p. 14)

Az adott költségvetési sor és a „nem állami” személyi veszteségek jobban védhetőek belpolitikailag, a konfliktusok gyakran rövidebb idő alatt oldódnak meg és kisebb költséggel járnak. Éves szinten a kiszerződött katonai tevékenységek meghaladják a 100 milliárd dollár összeget. A vonatkozó tevékenység a logisztikai szolgáltatástól, az őrzés- 
védelmen át a kiképzésig terjed. (Alston 2005) A legtöbb elemzés és értékelés tárgyává talán az Executive Outcomes és a Blackwater cégek tevékenysége vált. Előbbi délafrikai különleges alakulatokból létrejött, Dél-Afrikában bejegyzett vállalkozás, amely elsősorban afrikai országokban végzett katonai tevékenységet 1998-ig. A hivatalos állami megbízásoknak eleget tevő magánhadsereg 1.000 katonával, Boeing 727-es szállítógéppel, MIG-23-as vadászgépekkel, Mi-8-as és Mi-17-es helikopterekkel felszerelkezve végezte tevékenységét. Összehasonlításképpen a magyar hadsereg külföldön szolgálatot teljesítő békefenntartóinak létszámát a vonatkozó jogszabály 1.000 föben maximalizálja. A magyar hadsereg a MIG-23-as vadászgépeket 1996-ban vonta ki a használatból, míg a fenti helikopter típusok az értekezés megírásakor még hadrendben vannak. Az Executive Outcomes Sierra Leone-ban és Angolában végzett tevékenységével híresült el. Angolai szerepvállalása a költséghatékonyság iskolapéldájává vált: míg az ENSZ békefenntartók két éven keresztül összesen 730 millió dollár költséggel tartották fenn a békét, az angolai kormány közel 680 millió dollár költséggel sem tudta tárgyalóasztalhoz ültetni az felkelöket, az Executive Outcomes két, mindösszesen tizenegy napos katonai akcióval 60 millió dollár költséggel tárgyalóasztalhoz kényszerítette a feleket. (Job 1992) Az összehasonlítás természetesen nem egyszerüsíthető le arányszámokra, hiszen a három tevékenység párhuzamosan folyt, a nagyságrend mégis elgondolkodtató. A példa a számoktól függetlenül is jól alátámasztja, hogy hogyan vállalhatnak át nem állami szereplők olyan feladatokat - ebben az esetben katonaiakat - amelyeket az államok maguk, illetve nemzetközi szervezetek keretein belül nem képesek vagy politikai megfontolásból nem hajlandóak hatékonyan avagy egyáltalán felvállalni.

A Blackwater esete annak a jelenségnek a példája, amikor az államok távoli területeken folyó, potenciálisan jelentős áldozattal járó katonai beavatkozások egyes feladatait, esetenként egészét nem állami szereplőkkel végeztetik el szerződéses kötelem alapján, elkerülve ezzel a hazai társadalmi feszültségeket. A cég szerepe a terrorizmus elleni küzdelemben és elsősorban az iraki háborúban került a figyelem középpontjába, ahol egyszerre jelentett kapacitás kiegészítést, és a hadviselő felekre vonatkozó jogszabályok rugalmas értelmezésének lehetőségét. Becslések szerint Irakban 15.000 és 20.000 fö közé tehető a szerződéssel foglalkoztatott, a biztonsági szektorban tevékenykedő személyek száma. Alkalmazásuk tudatosan aknázta ki - más katonai konfliktusokban jelenleg is - az állami és a nem állami szereplők jogai, kötelezettségei, szuverenitása és felelősségre vonhatósága szabályozásának hiányosságait. A nem állami szereplőkkel 
kapcsolatos romantikus felfogást, és annak megkérdőjeleződését jól mutatja a közvélemény, illetve a média felismerése, hogy tevékenységük egyre inkább hasonlít egy profit-orientált magánhadseregére (Barstow 2004) - holott ezek a cégek a kezdetektől fogva nyíltan profit-orientált magán hadseregek.

A hagyományosan állami fennhatóság alá tartozó katonai vagy rendőri tevékenység gyakorlásának joga a lakosság feletti szuverenitás de facto korlátozása, vagyis az adott nem állami szereplő fogadó állammal szembeni befolyásának érvényre juttatása a két fél közötti bármely jogi kötelem megléte nélkül. A lakossággal szembeni hatalom gyakorlását teszi lehetővé, ami jogszerü vagy - sajnos egyre több esetben - jogszerütlen is lehet. A magán biztonsági cégek tevékenységével kapcsolatos botrányoktól függetlenül ez az eljárás megoldást kínált a hidegháborút követően a hadsereggel szemben megfogalmazódott morális fenntartásokra. Ennek a megközelítésnek a biztonság koncepciójának globalizációja miatt egyre nagyobb szerepe lehet a 21 . században. (Coker 2001) Csakhogy ez a megoldás egy jelentős problémát hordoz magában: a szerződött nem állami szereplők jogi felelőssége tisztázatlan, és számon kérhetőségük korlátozott. (Alston 2005)

A katonai erő alkalmazásának képességével és esetenként jogával bíró nem állami szereplök számának és erejének növekedésével még nem következett be az erőviszonyoknak az a típusú megváltozása, amilyenre a gazdasági szférában sor került az elmúlt évtizedekben. Az erőszak alkalmazásának képességével bíró egyes nem állami szereplők elérték azt a szintet ahol az államok helyett vagy akár ellenében hatékonyan fel tudnak lépni. Ez azonban relatív alacsony számukból adódóan jelenleg nem általánosítható. 


\section{FEJEZET \\ A NEM ÁLLAMI SZEREPLŐK SZÁMÁNAK ÉS SZAKIRODALOMBAN VALÓ MEGJELENÉSÉNEK VÁLTOZÁSA}

A nem állami szereplők befolyásának változása több tényező együttállásából adódhat. Egyrészt a szereplők számának növekedéséből, és ezen keresztül az interakciók számának emelkedéséből; másrészt az érdekérvényesítési képesség hatékonyságának növekedéséből; és harmadrészt a rendszerszintủ változások következtében módosuló erőviszonyokból. Miután fentebb megvizsgáltam a rendszer szintủ változásokat és a képességek alakulását, ebben a fejezetben a szereplők számára koncentrálok.

Bár nem törvényszerüen, de feltételezhetően az interakciók számának növekedése következtében a többi szereplő magatartása jelentősebb mértékben módosul. Az elért hatás együtt mozog a kölcsönhatások számával, vagyis a nem állami szereplök számának alakulásával. Kvantitatív elemzésük ${ }^{46}$ kapcsán több fontos kitételt kell figyelembe venni. Mindenekelött a definíció kapcsán már említett korlátot, nevezetesen, hogy negatív meghatározásuk „nem” állami szereplőként megnehezíti számbavételüket is. Az alábbiakban is speciálisan meghatározott csoportjukon keresztül mutatok rá a számszerü növekedés sajátosságaira. Ugyancsak a definícióból levezethető, hogy a nem állami szereplök tevékenységükön keresztül, aktív fellépésük révén válnak a transznacionális kapcsolatok szereplöivé. Vagyis a statisztikai számbavétel a tevékenység alapján igazolható, és nem hagyományos regisztráció alapján, és csak akkor lehetséges, ha a tevékenység ismertté válik az elemzést végzők számára.

A nem állami szereplök kvantitatív elemzése eltér a hagyományos megközelítéstöl. A témával foglalkozó szerzők többsége, ahogy Arts (2003), Josseline és Wallace (2001), Le Gloannec (2007) vagy Risse-Kappen (1995), szociológiai vagy politológiai háttérrel rendelkezik, és elsősorban ilyen megközelítésből elemzi - gyakran esettanulmányok formájában - a nem állami szereplők tevékenységét. Nye (2011) a nemzetközi nem kormányzati szervezetekre vonatkozóan számszerüsíti a változást, és közel 150-szeres növekedést mutat ki a 20. század folyamán: 176-ról 26.000-re nőtt a számuk. A hatodik fejezetben bemutatott kvalitatív elemzést a következökben részletezett kvantitatív

\footnotetext{
${ }^{46}$ A lehetséges kvantitatív elemzés paramétereiről lásd részletesebben Bloodgood (2011) tanulmányát.
} 
megközelítéssel egészítem ki. Így kapunk komplex képet a nem állami szereplők befolyásának változásáról.

A nem állami szereplők dominánsan cselekvés-orientált számba vétele egyrészt nehezíti a pontos kvantitatív elemzést, másrészt ugyanakkor közvetett módon pontosabb képet ad arról, hogy a nem állami szereplők befolyása hogyan alakul, hiszen a befolyás alapvetően - ha nem is kizárólagosan - cselekvésen keresztül érvényesíthető. Elsőként a nem állami szereplök számára vonatkozó adatokat elemzem, majd megvizsgálom, hogy a szakirodalomban történő említésük, a vonatkozó elemzések száma hogyan változott az elmúlt évtizedekben. Célom nem az abszolút számok összehasonlítása, hanem számuk változásának, és végső soron ebből következtetve befolyásuk változásának bemutatása. Míg számuk változása pontosabb trend-meghatározást tesz lehetővé, a vonatkozó említések számából levonható közvetett következtetés véleményem szerint jobban tükrözi az aktivitás változását, mivel jellemzően elemzések csak érdemi hatást kiváltott események kapcsán születnek, vagyis épp olyan esetekben, ahol a nem állami szereplök képesek voltak érdemben befolyásolni a transznacionális folyamatokat vagy más szereplőket.

A legnagyobb adatbázis a Yearbook of International Organizations, valamint az ENSZ nyilvántartásában található. Az évkönyv különböző kategóriákban, a szervezetek közvetlen megkeresésével állítja össze adatbázisát. Adatai öt éves csúszással értelmezendők, mivel a kiadványba csak azok kerülnek bele, amelyek öt egymást követő évben kitöltötték a rájuk vonatkozó információkat, valamint azok kerülnek törlésre, akikről legalább öt éve nem áll rendelkezésre aktív információ. Az évkönyv adatait elemezve egyértelmü növekvő trend rajzolódik ki a 6. ábrán: megállapítható, hogy a nemzetközi nem kormányzati szervezetek (INGO) száma 1968-2004 között négyszeresére emelkedett. Az inaktívak számának figyelembe vételével az aktívak száma háromszorosára nőtt. 
6. ábra: Nemzetközi nem kormányzati szervezetek száma

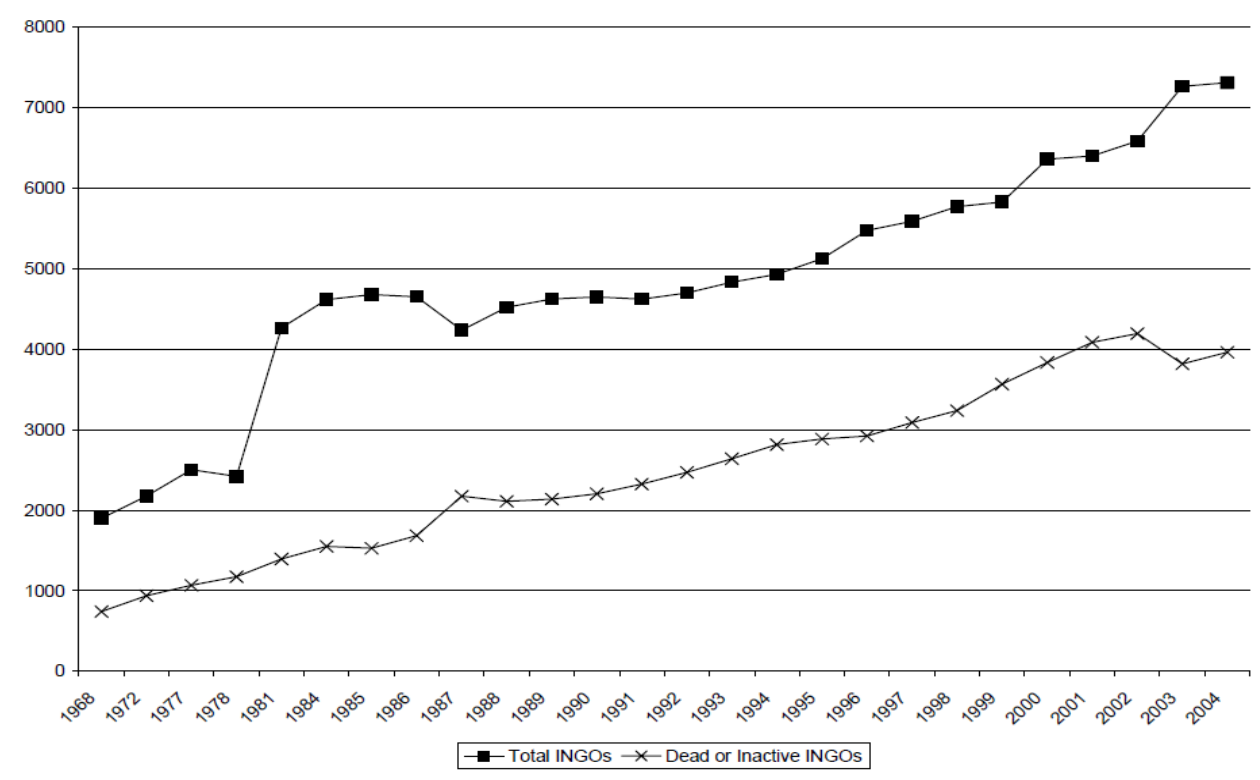

Forrás: Reinalda 2011, p. 24

Az ENSZ Gazdasági és Szociális Tanácsa (ECOSOC) konzultatív státust biztosít az NGO-k számára. Nyilvántartásuk szerint 1946-ban 41, 1992-ben 700, míg 2012-ben 3400 NGO rendelkezett ezzel a státussal, és folytatott aktív tevékenységet a nemzetközi szervezet szintjén. ${ }^{47}$ A 6 . ábrán látható adatsor jól mutatja, hogy az 1980-as évek elején történt ugrásszerü növekedés, majd egy évtizednyi stagnálás után a hidegháború végét követően az 1990-es évektől tapasztalható folyamatos és egyenletes növekedés. Utóbbi egyértelmüen a nyugati tömbhöz csatlakozott volt szocialista országok civil társadalmának aktivizálódásának eredménye, de a folyamat érzékelhetően Ázsia és Afrika több országában is dinamizálódik.

A nem állami szereplök számának növekedésén túl a szakirodalomban található említések számának változása alkalmas annak szemléltetésére, hogy a tevékenységük által kiváltott hatás hogyan módosul, és pontosabb képet nyújt az egyes alkategóriák aktivitásának és megítélésének változásáról is. Az elemzéshez két könyvtári adatbázis vizsgálatát végeztem el. A United States Library of Congress az egyik legnagyobb és legátfogóbb adatbázissal rendelkezik, világviszonylatban reprezentatív mintának tekinthető, így jól alkalmazható általános képet ad. A Johns Hopkins University könyvtárának merítése szükebb, koncentráltabb szelekció a nemzetközi kapcsolatok szakirodalmára vonatkozóan. A 2013 januárjában elvégzett kutatás során négy

\footnotetext{
${ }^{47}$ http://csonet.org/index.php?menu=30 Letöltve: 2013 . január 27.
} 
kategóriára, egy főkategóriára és három alkategóriára, vonatkozóan végeztem felmérést az 1951-től 2012-ig terjedő időszakra, illetve készítettem extrapolálást 2020-ig. Évtizedes bontásban összesítettem azokat a publikációkat (könyv, tanulmány, cikk, elektronikus könyv, online cikk, stb.), amelyek címében valamely kifejezés megtalálható az alábbiak közül: „nem állami szereplők”, „(nemzetközi) nem kormányzati szervezetek”, „transznacionális vállalatok” és „transznacionális érdekképviseleti hálózatok”. Ezt a 7. ábra szemlélteti.

7. ábra: Nem állami szereplők említésének száma a szakirodalomban I.

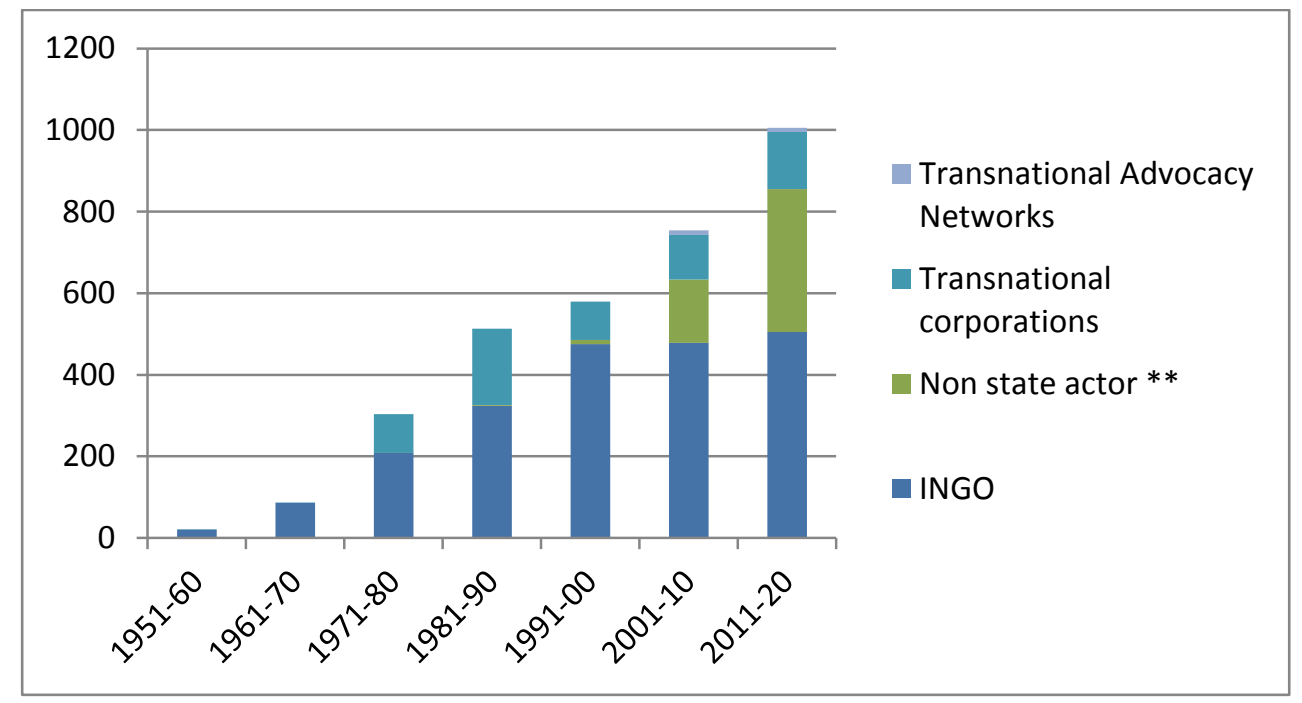

** non state actors, non-state actors és nonstate actors kifejezések együtt

Megjegyzés: a 2011-2020 időszakra vonatkozó adat a felmérés 2011-2012-es adatainak extrapolálása

Forrás: Library of Congress Catalogue

A grafikon értelmezésekor fontos kiemelni, hogy a disszertáció elején tárgyalt definíciós probléma, valamint a szakirodalomban a szerzők által használt eltérő megközelítések miatt az egyes kategóriák részben átfedhetik egymást, valamint nem teljes mértékben feleltethetőek meg a jelen disszertációban használt fogalmaknak. Ez elsősorban a két újabb fogalom - a nem állami szereplök és a transznacionális érdekképviseleti hálózatok - esetében lényeges kitétel, mivel az NGO/INGO és a TNC fogalma az elmúlt évtizedek során kellő mértékben letisztult. Előbbiek esetében azonban elöfordul, hogy a fogalom egyéni definíciói között eltérések vannak, de ez a vizsgálat szempontjából nem jelent problémát, mivel nem befolyásolja a szemlélet változás tényét. A nem állami szereplők kifejezés például az 1980-as évektől jelenik meg, ugyanakkor nem váltja ki, hanem gyüjtőfogalomként párhuzamosan létezik a korábban használtakkal. A kutatás során nem vizsgáltam minden fogalmat, amely az 
általam használt definíció részét képezi, hanem szakértői kiválasztással meghatároztam azokat a fogalmakat, amelyek legszemléletesebben mutatják a változásokat. A „nem állami szereplök” mellett a „(nemzetközi) nem kormányzati szervezetek”, „transznacionális vállalatok” és a „transznacionális érdekképviseleti hálózatok” kifejezésekre terjedt ki a vizsgálat.

Az említések számának összessége egyértelmü és jelentős mértékű növekedést mutat. Az első vizsgált évtizedben (1951-60) mért 22-ről az utolsó időszakban (2011-20) becsült 1005-re nőtt, vagyis közel 50-szeresére emelkedett. Ez alátámasztja azt a feltételezést, hogy a különböző nem állami szereplök összességében a transznacionális kapcsolatok mind aktívabb résztvevőivé válnak. A növekedés üteme közel egyenletes, kivéve a gyorsabb növekedést mutató 1980-as évtized, valamint a disszertáció megírásának évtizede.

Az adatokat egy-egy részadat változása magyarázza. Az 1940-es évek végétől indult el látványosan az NGO-k, illetve az INGO-k tevékenysége. A vizsgált alkategóriák közül csak a nemzetközi nem kormányzati szereplökre történik utalás a szakirodalomban az első két periódusban. Jelenlétük mind a mai napig megmaradt, de az említések száma 1991-től stagnál. Az 1970-es években jelenik meg a transznacionális vállalat kifejezés a szakirodalomban. Az adott évtizedben végbement globális pénzügyi forradalmat követően a világkereskedelem liberalizációja ekkorra érte el azt a szintet, hogy a transznacionális vállalati aktivitás szignifikánssá vált, és az elemzések a téma mind több aspektusát kezdték vizsgálni. Az 1980-as évtized kiugró adatait a TNC-kre vonatkozó elemzések számának megugrása magyarázza. Ebben az évtizedben jelenik meg a nem állami szereplő fogalma, és a 2011-20 közötti periódusban várhatóan ugrásszerüen emelkedik az említések száma a szakirodalomban. Ez magyarázza az említések számának összességére vonatkozó másik kiugró adatot. A globalizáció és a hálózatosodás további fejlődésének eredményeként a 2000-es évek elejétől megjelent a transznacionális érdekképviseleti hálózat (TAN) fogalma a vonatkozó irodalomban. A globális kihívások formáinak bővülésével és számának növekedésével, valamint a hálózatos globális kommunikáció korábban ismertetett egyszerüsödésével a TAN lehet a következő kiemelkedő téma.

A nem állami szereplők, mint koncepcionális megközelítés létjogosultságát, sőt növekvő jelentőségét mutatja a fenti elemzés. Ennek továbbgondolását a washingtoni Johns Hopkins Egyetem könyvtári adatbázisának elemzésével végeztem el. A 8. számú ábra a hagyományosan elterjedt nem kormányzati szervezet kifejezés és a disszertáció 
vizsgálatának tárgyát képező nem állami szereplő kifejezés gyakoriságát mutatja. A nem állami szereplő kifejezés használata - amint azt a szakirodalom áttekintésekor láttuk - nem egyszerü terminológiai változást jelent. Sokkal szélesebb körét fedi le azoknak a szereplőknek, amelyek aktivitása az államok mellett vagy esetenként azok ellenében alakítja a transznacionális kapcsolatokat. Jelentős koncepcionális elmozdulást tükröz az állam központú modellhez képest. Ebből kifolyólag a kifejezés elterjedése a szakirodalomban közvetett módon azt is mutatja, hogy a nem állam központú megközelítés fokozatosan teret nyer. A fenti két fogalom - nem kormányzati szervezet és nem állami szereplő - használatát az alábbi grafikon mutatja:

8. ábra: Nem állami szereplők említésének száma a szakirodalomban II.

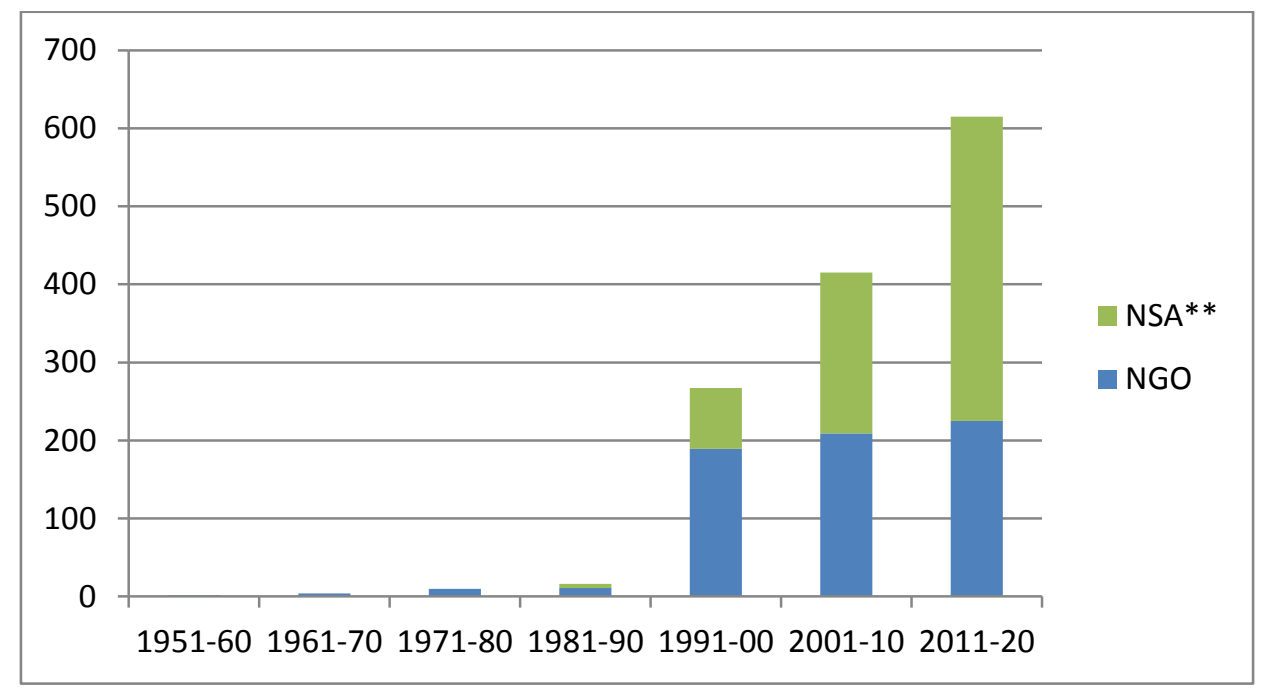

** non state actors, non-state actors és nonstate actors kifejezések együtt Megjegyzés: a 2011-2020 időszakra vonatkozó adat a felmérés 2011-2012-es adatainak extrapolálása

Forrás: Johns Hopkins Libraries Collection

A fentiekhez hasonlóan megállapítható, hogy az 1980-as évekig a nem kormányzati szervezetekkel foglalkozott a szakirodalom. A nem állami szereplők kifejezéssel jellemezhető tágabb megközelítés csak ettől az évtizedtől kezdődően tapasztalható, ám a 2000-es évek első évtizedében az említések számát tekintve még alatta marad, illetve megegyezik a nem kormányzati szervezetek kifejezés említésével. 1991-től az NGO kifejezés említésének száma stagnál, míg a NSA fogalomé exponenciálisan növekszik. A bipoláris nemzetközi rendszer felbomlásával a tudatosan elfojtott lokális konfliktusok egy része a felszínre került. Az államok közötti szembenállás helyett az egy államon belüli, különböző érdekcsoportok közötti konfrontáció vált meghatározó problémává, ami definíció szerint ráirányította a figyelmet a nem állami szereplökre, mint a 
konfliktus résztvevőire. Később a transznacionális problémák iránti figyelem erősödése hasonlóan a transznacionális nem állami szereplök lehetséges hozzájárulását tette az elemzés tárgyává.

2011-től annak lehetünk tanúi, hogy az NSA-k említése jelentősen meghaladja az NGOkról szóló írások számát. A nem állami szereplőkről készült publikációk számának növekedése alátámasztja, hogy aktivitásuk növekszik, és megerösíti, hogy egyre gyakrabban kerülnek az elemzők számára értékelhető interakcióba más szereplőkkel, illetve képesek érdemi befolyást gyakorolni a transznacionális folyamatokra.

A kvantitatív elemzés nem ad választ arra a kérdésre, hogy a fellépés hatékony volt-e, és arra sem, hogy az érdekérvényesítés eredményesen végződött-e, vagyis a kölcsönhatás másik szereplője változtatott-e a magatartásán. Ahogy értelemszerüen azt sem tárja fel az elemzés, hogy a cselekvést jó vagy rossz szándék vezérelte-e, vagyis célja pozitív volt-e vagy negatív. Ezekkel a minőségi kérdésekkel a korábbi fejezetben ismertetett kvalitatív elemzés foglalkozott. Mivel arra keresem a választ, hogy nőtt-e a nem állami szereplők befolyása, a kvantitatív elemzés alapján azt állapítom meg, hogy azok aktivitása és az interakciók száma növekedett, és a nem állam-központú megközelítés használata is egyre nagyobb mértékben terjed. Ez közvetett módon azt támasztja alá, hogy a nem állami szereplők mozgástere növekszik, és megerősíti feltételezésünket, hogy ezen keresztül befolyásolási képességük is erősödik. 


\section{FEJEZET \\ KONKLÚZIÓ}

A disszertációban arra a kérdésre kerestem a választ, hogy a nem állami szereplők jelenléte és megnövekedett aktivitása jelenti-e egyben befolyásuk erösödését a nemzetközi kapcsolatok alakításában, a globális kihívások megválaszolásában, illetve a transznacionális problémák megoldásában. A nem állami szereplök transznacionális kapcsolatokban játszott szerepét befolyásoló tényezőket vizsgáltam. Elsődlegesen a rendszer sajátosságait elemeztem deduktív módon, majd a nem állami szereplőkre vonatkozóan kvalitatív és kvantitatív vizsgálatokat végeztem.

Az elméleti keretek meghatározása során megállapítottam, hogy a nem állami szereplők tevékenységének vizsgálatakor a nemzetközi kapcsolatok helyett a transznacionális kapcsolatokat kell alapul venni, amelyek jelentősége napjainkban folyamatosan növekszik. Az elemzés ezért a transznacionális kapcsolatok elméletéből indult ki, amely a rendszer mozgatórugójának tekintett hatalom vizsgálatakor Keohane és Nye megközelítését veszi alapul. A rendszer szintjén a szereplők közötti interakciókra vonatkozó elemzést végeztem. A 21. században megkerülhetetlenné vált a befolyás érvényesítése különböző szintjeinek vizsgálata: a katonai képességek mellett egyre meghatározóbb szerepet játszik a gazdasági erő, és a nemzetközi, illetve transznacionális szereplők számának emelkedésével növekszik a vonzás hatalmának jelentősége is. A transznacionális konfliktusok előtérbe kerülése miatt a befolyásolás csatornáinak hatékonysága változik. Megnövekedett a soft power eszközökkel kezelhető kérdések száma és jelentősége, és ennek következtében azok a szereplők, amelyek korábban a katonai képességek híján háttérbe szorultak, relatív értelemben nagyobb befolyásolási képességre tesznek szert.

A szereplők képességeik változása szempontjából történő elemzésénél Matthews „új középkor" elméletéből indultam ki, amely szerint a felmerülő új típusú nemzetközi problémákat már nem az államok fogják tudni leghatékonyabban megoldani, hanem a különböző államok alatti és feletti szereplők befolyása lesz meghatározó. Minden nemzetközi és transznacionális szereplő befolyásolási képessége ugyanazon elemekből tevődik össze: katonai hatalom, gazdasági hatalom és a vonzás hatalma. Az állami és a nem állami szereplők is ezekkel rendelkeznek, csak eltérő mértékben. Az államok jóval 
nagyobb katonai hatalommal bírnak, a nem állami szereplők többsége pedig hagyományosan nagyobb mértékben a vonzás hatalmával. Megállapítottam, hogy az 1970-es évek NGO-kra vonatkozó romantikus megközelítésével szemben ma már a vonzás hatalmának birtoklása nem magától értetődő, így nem minden szereplő megítélése pozitív. A jelenlegi tendencia azt mutatja, hogy a nem állami szereplők fokozatosan gyarapítják gazdasági hatalmukat is. Az elmúlt évtizedekben a nem állami szereplők szintjén két látványos változás ment végbe. Egyrészt abszolút értékben megnőtt a gazdasági és katonai képességük - előbbi jelentős mértékben, utóbbi csak bizonyos esetekben. Másrészt relatív értelemben megváltozott a hatalom összetevőinek az érdekérvényesítésben játszott szerepe. A vesztfáliai kudarcok, valamint a 21. században várhatóan meghatározóvá váló új kihívások a korábbiaktól eltérő képességeket helyeznek elötérbe. A felmerülő konfliktusok feloldásában nagyobb mértékben érvényesül a gazdasági hatalom és a vonzás hatalma, mint a katonai hatalom. Így azok a szereplők, amelyek korábban katonai képességek hiányában hátrányban voltak, relatív értelemben nagyobb befolyásolási képességre tettek szert anélkül, hogy saját képességeik változtak volna. A hálózatosodás ugyancsak a nem állami szereplöknek kedvez. A képességek abszolút változása valamint a gazdasági és vonzás hatalmának relatív felértékelődése - mint azokat a disszertációban részletesen ismertettem -együtt a nem állami szereplők befolyásolási képességének növekedését eredményezte, összességében azonban a nem állami szereplők hatalma minden hatalmi típust figyelembe véve nem vált dominánssá.

$\mathrm{Az}$ államok bizonyos területeken önként, bizonyos esetekben kényszerből átadják helyüket a nem állami szereplőknek, amelyek az állami szint alatt, felett vagy helyett jelennek meg. A rendszer szereplői közötti kapcsolatok vizsgálatakor Risse-Kappen elemzési keretét fogadtam el, kiegészítve azt a kormányzati funkciók átvételének vizsgálatakor Slaughter megközelítésével. Jelentős változásnak értékelem, hogy míg korábban a nem állami szereplők az államokkal szemben kooperatív stratégiát követtek (emberi jogok, környezetvédelem, szabályozás alakítása), egyre több olyan területen jelennek meg, ahol kompetitív vagy konfrontatív magatartást folytatnak (gazdasági érdekek, erőszak monopóliumának megszerzéséért folytatott küzdelem). E kölcsönhatások létrejötte annak tudható be, hogy egyes témák nagyobb szerepet kapnak a korábbiakhoz képest, és a nem állami szereplők relatív képességeinek megnövekedése lehetővé teszi számukra az aktív fellépést. Képességeik abszolút vagy relatív növekedése tudatában a nem állami szereplők felvállalnak olyan lépéseket is, amelyek 
kompetitív vagy konfrontatív helyzetbe kényszerítik a hagyományosan meghatározónak tekintett államokat. Ez az elmozdulás alapvetően befolyásolja a transznacionális kapcsolatok jövőjét.

\section{A) Az államok dominanciája nem szünik meg}

Az 'A' hipotézis azt feltételezte, hogy a 21. században a nem állami szereplők számának és befolyásának növekedésével a nemzetközi rendszer állami dominanciája megszünik, az államok közötti kapcsolatok helyett a transznacionális kapcsolatok válnak meghatározóvá.

A nemzetközi politikai és gazdasági rendszer 21. századi sajátosságainak elemzése azt mutatta meg, hogy a globalizáció hatásai, a globális kihívások és az azokra adandó állami válaszok nehézségei új lehetőséget jelentenek a nem állami szereplők számára. A nemzetközi kapcsolatok új értelmezést kapnak, és a transznacionális kapcsolatok jelentősége növekszik. A disszertációban külön kitértem a nemzetközi és a transznacionális kapcsolatok közötti különbségre. Megvizsgáltam, hogy a külpolitika „belpolitizálódása” és a belpolitika külpolitikai vonatkozásainak felerősödése a különböző szereplők között milyen új kapcsolatok kialakulását eredményezi.

Elemzésem cáfolta az 'A' hipotézist. Az államok dominanciája a nemzetközi rendszer egésze szintjén nem szünt meg, egyes területeken azonban csökkent. Ez a befolyás csökkenés eltérő mértékű, mindenesetre egyik vizsgált területen sem beszélhetünk a nem állami szereplők kizárólagos befolyásáról. A nem állami szereplők aktivitása elsősorban a transznacionális kapcsolatok körébe tartozó területeken válhat meghatározóvá - kihasználva a hálózatosodást és a kommunikációs költségek csökkenését. A gazdasági hatalom és a vonzás hatalma jelentőségének relatív növekedése tovább erősíti ezt a tendenciát. Ezeken a területeken a nem állami szereplők befolyása folyamatosan nő. A transznacionális kapcsolatok köre és a transznacionális hálózatok kiterjedtsége jelentős mértékben és folyamatosan bővül, ugyanakkor az államközi kapcsolatok továbbra is a nemzetközi kapcsolatok szerves részét képezik.

\section{B) Az „új középkorban” a hatalom több kézben oszlik meg}

A 'B' hipotézis szerint a politikai tér átrendeződése és a hatalom jellemzőinek átalakulása egy „új középkor” kialakulását eredményezi, ahol a hatalom több kézben oszlik meg. Az elemzés rávilágított, hogy állami funkciók bővülése, a be nem töltött állami funkciók által létrehozott vákuum, valamint a vákuum betöltésére képes és kész 
nem állami szereplők megjelenése, illetve megerősödése nemzeti szinten és a transznacionális kapcsolatokban is átrendeződést eredményezett.

A globális problémák megjelenése, valamint a határokon átnyúló kihívások számának növekedése egyre nagyobb teret enged a transznacionális nem állami szereplök fellépésének. A belpolitika „külpolitizálódása”, és a lokális problémák megjelenése a világtársadalom szintjén az adott kérdéssel foglalkozó szakértői csoportok kapcsolati hálójának kialakulásához, illetve megerősödéséhez vezet. A be nem töltött állami funkciók - függetlenül attól, hogy azt az állami szereplő nem kívánja vagy nem képes elvégezni - teret engednek a nem állami szereplők fellépésének. Az egyes szakterületeken felhalmozott speciális tudás birtoklása a globális kommunikáció adta lehetőségek kihasználásán keresztül felértékeli a szakosodott nem állami szereplőket azokon a területeken, ahol a véleményformálásban, illetve az érdekérvényesítésben a hírnév, a szakmai elismertség meghatározó tulajdonságok. Sok esetben - pl. a környezetvédelem területén - a nem állami szereplők fellépése konfrontatív stratégia mentén történik. Az emberi jogok területén és kimondottan a segélyezési politikában a nem állami szereplők gyakran azokat a feladatokat látják el, amelyeket az államok a szuverenitás alapelvére, a belügyekbe való beavatkozástól való tartózkodásra hivatkozva nem kívánnak ellátni. Ezekben az esetekben kooperatív stratégiáról beszélünk.

A szereplők számának növekedése, és a hatalom több kézben történő megjelenése a gazdaság területén a leglátványosabb, ahol a kompetitív vagy a konfrontatív megközelítés dominál. A 20. század végétől a globalizált piacok és elsősorban a pénzpiacok müködési mechanizmusainak következtében a nem állami szereplők a közvetlen államokkal szemben folytatott befolyásolási, érdekérvényesítési tevékenységükön túlmenően közvetett hatást képesek gyakorolni az államokra más nem állami szereplőkön keresztül, amelyek megsokszorozzák az eredeti hatást. Korábban a kölcsönhatás csak az abban részes szereplőkre hatott, és a nem állami szereplők (pl. gazdasági társaságok) célja a rájuk közvetlenül vonatkozó állami szabályozás és velük szemben tanúsított állami fellépés alakítása volt. Ma már egyes pénzügyi nem állami szereplők (pl. hitelminősítő intézetek) lépései olyan mértékben képesek befolyásolni más nem állami szereplők gazdasági döntéseit, hogy az államoknak csak a szabályozás vagy döntés illúziója marad. Ez a hatás már - áttételeken keresztül ugyan, de - az állam más funkcióit is érintheti, vagyis a nem állami szereplőt olyan befolyásolási képességhez juttatja, ami túlmutat az általa kifejtett tevékenység határain. 
A katonai hatalom területén - részben a technológiához való hozzáférés könnyebbé válása, részben a katonai képességek finanszírozásához szükséges gazdasági erő fentebb részletezett növekedése miatt - szintén megfigyelhető bizonyos fokú elmozdulás. Az erőszak alkalmazásának képességével bíró egyes nem állami szereplők elérték azt a szintet ahol az államok helyett vagy akár ellenében hatékonyan fel tudnak lépni. Ez azonban - relatív alacsony számukból adódóan - jelenleg még nem érte el azt a kritikus tömeget, amely megkérdőjelezné az államok dominanciáját. A katonai erő alkalmazásának képességével és esetenként jogával bíró nem állami szereplők számának és erejének növekedése egyértelmü, de nem következett be az erőviszonyoknak az a típusú megváltozása, amilyenre a gazdasági szférában sor került az elmúlt évtizedekben. Ezek alapján megállapítható, hogy a nem állami szereplők legyen szó TNC-kről, pénzügyi vagy katonai szereplőkről - képesek sokszereplős globalizált rendszerekben az államokkal szemben közvetlenül, vagy a többi szereplő magatartásának befolyásolásán keresztül közvetett módon olyan hatást gyakorolni, amelyet az államok egyáltalán nem vagy csak részben tudnak ellensúlyozni.

Külön fejezetben vizsgáltam a nem állami szereplök más nemzetközi aktorokkal való érintkezésének formáit és az interakciók különböző szintjeit. Megállapítottam, hogy más stratégiát kíván meg az államokkal szembeni érdekérvényesítés, a nemzetközi szervezetekkel szembeni befolyás érvényesítése, valamint a nem állami szereplők egymás közti viszonyainak alakítása. Minden esetben igaznak bizonyult, hogy áttételeken keresztül ugyan, de a nem állami szereplők befolyása más nem állami szereplőkre az államok alatti vagy feletti szinten (NGO-k, TNC-k, nemzetközi szervezetek, stb) áttételesen hat az államokra, és ez a hatás a nem állami szereplők befolyását erősíti.

A 'B' hipotézist az elemzés alapján bizonyítottnak fogadom el. Az új típusú konfliktusokban a hatalom összetevői relatív súlyának megváltozása, valamint az egyes hatalmi tényezők birtoklása a nem állami szereplők pozícióját erősíti. Az állami és nem állami szereplők közötti erőviszony a transznacionális kapcsolatokban a hatalom birtoklásának kiegyenlítődése eredményeként minőségileg megváltozott. A nem állami szereplők pozíciója kedvezőbbé vált.

\section{C) Hatalmi transzfer megy végbe az államoktól a nem állami szereplők felé}

A 'C' hipotézis azt állította, hogy a nem állami szereplők számának és képességeinek növekedése miatt hatalmi transzfer megy végbe az államoktól a nem állami szereplők 
felé, amelyek ezáltal az államok konkurenseivé válnak. Ez adódhat az érdekérvényesítési, illetve befolyásolási képességek kedvező irányú változásából, illetve a befolyásolásra irányuló lépések számának növekedéséből. Amint azt fentebb összegeztem, az értekezés bizonyította, hogy a nem állami szereplők egyes területeken - pl. gazdasági szabályozás, erőszak monopóliuma - nem csak az államok egyetértésével, de azok akarata ellenében is képesek érdekeiknek érvényt szerezni, vagyis azok konkurensévé válni. Ez azonban csak egyes területeken figyelhető meg, míg más területeken inkább együttmüködésről beszélhetünk - pl. emberi jogok. A jövőben várhatón tovább növekszik azoknak a területeknek a jelentősége, ahol a nem állami szereplök befolyása növekedést mutat. A 'B' hipotézis bizonyítása azt is megmutatta, hogy a rendszer szintű változásokon túlmenően a nem állami szereplők adottságainak változása mennyiben teszi képessé azokat arra, hogy növeljék befolyásukat a nemzetközi kapcsolatok más szereplőire.

A fenti megállapításokat megerősítette az értekezés utolsó fejezetében ismertetett kvantitatív elemzés, amely a nem állami szereplők számának és aktivitásának növekedését bizonyította. A vizsgálat elvégzéséhez olyan leegyszerüsített, ugyanakkor reprezentatív módszert választottam, amely közvetett mérőszámokkal számszerüsítette szerepük, jelentőségük változását. A vizsgált évtizedekben a nem állami szereplők szakirodalomban történt említéseinek száma a kezdeti időszakban (1951-60) mért 22-ről az utolsó időszakban (2011-20) becsült 1005-re nőtt, vagyis közel 50-szeresére emelkedett. A vizsgálat kiindulópontja, hogy a nem állami szereplőkről született publikációk leggyakrabban valamely konkrét esemény kapcsán születnek, jól tükrözve azt, ha a nem állami szereplők érzékelhető, kimutatható hatást váltottak ki. A növekedés üteme közel egyenletes, kivéve a gyorsabb növekedést mutató 1980-as, valamint 2000es évtizedet. 2011-tôl annak lehetünk tanúi, hogy a nem állami szereplők említése jelentősen meghaladja az nem kormányzati szervezetekről szóló írások számát. A nem állami szereplőkröl készült publikációk számának növekedése alátámasztja, hogy aktivitásuk növekszik, és megerősíti, hogy egyre gyakrabban kerülnek az elemzők számára értékelhető kölcsönhatásba más szereplőkkel, illetve képesek mérhető hatást, érdemi befolyást gyakorolni a transznacionális folyamatokra.

A kvantitatív elemzés nem adott választ arra a kérdésre, hogy a fellépés hatékony volte, és arra sem, hogy az érdekérvényesítés eredményesen végződött-e, vagyis a kölcsönhatás másik szereplője változtatott-e a magatartásán. Azt sem tárja fel az elemzés, hogy a cselekvés célja pozitív vagy negatív irányú befolyásolás volt-e. 
Ezekkel a minőségi kérdésekkel a disszertáció kvalitatív elemzési része foglalkozott. Mivel arra kerestem a választ, hogy nőtt-e a nem állami szereplök befolyása, a kvantitatív elemzés alapján azt állapítom meg, hogy azok aktivitása és az interakciók száma növekedett, és a nem állam-központú megközelítés használata is egyre nagyobb mértékben terjed. Bár az elért hatás pontos mértékét nem lehet ezzel a módszerrel kimutatni, ez közvetett módon alátámasztja, hogy a nem állami szereplők mozgástere növekszik és ezen keresztül befolyásolási képességük erösödik. A számszerü eredmény alátámasztotta a közvetett elméleti következtetések alapján kialakult álláspontomat a hipotézis helyességére vonatkozóan. Ezek alapján a „C” hipotézist részben igaznak fogadom el. Elemzésem igazolta, hogy megvalósul a hatalmi transzfer az államoktól a nem állami szereplők felé. Ugyanakkor ez a változás csak bizonyos területeken teszi képessé a nem állami szereplőket arra, hogy az államok konkurenseivé váljanak, más területeken a korábbi erőviszonyok nem változnak meg ilyen mértékben.

A kutatás során arra kerestem a választ, hogy növekszik-e a nem állami szereplők befolyása a nemzetközi és elsősorban a transznacionális kapcsolatokban. Az általam megvizsgált részkérdések, bemutatott folyamatok és az ezekből levont következtetések mind ebbe az irányba mutattak, tehát a válasz igen. A disszertáció során mindvégig törekedtem a kiegyensúlyozott megközelítésre, és az eltérő véleményeket is figyelembe vettem. Ráirányítottam a figyelmet azokra a negatív szerepekre, kritikai észrevételekre, legitimációs kérdésekre is, amelyeket a szakirodalom felvet, és amelyeket kutatásaim alapján én magam is relevánsnak tartok. Az 1970-es évek románcának vége, amikor az elemzések egy idealizált feltételezésből indultak ki, és az NGO-k tevékenységét kizárólag pozitívnak tekintették. A kritikai észrevételek ismerete fontos kiegészítése a nem állami szereplők nemzetközi jelenlétéröl kialakult képnek. A disszertáció számos új kérdést is felvetett, amelyek további elemzésre érdemesek, de nem képezik jelen értekezés tárgyát, például: Mennyire reprezentatívak, illetve milyen alapsokaságra nézve reprezentatívak a nem állami szereplők? A reprezentativitás jelent-e egyben legitimációt is? Hogyan és ki által számoltathatóak el, illetve elszámoltathatóak-e egyáltalán? Ahogy a nem állami szereplők befolyása mind láthatóbbá válik, ezek a kérdések egyre fontosabbak lesznek. Megválaszolásuk új kutatások témája lehet.

A kutatás ráirányította a figyelmet a transznacionális kapcsolatok jelentőségének növekedésére. A 20. század során elindult, és a 21. században bizonyosan folytatódó trendek, valamint a változó kihívások a transznacionális kapcsolatok szereplőinek befolyását erősítik. A nem állami szereplők a korábbinál nagyobb számban jelennek 
meg ezen a szinten, és érdekeik érvényesítéséhez is több eszközzel, relatív értelemben nagyobb hatalommal rendelkeznek. A nem állami szereplők megnövekedő befolyása átalakítja a szereplők viszonyait - legyen szó akár állam és nem állami szereplő kölcsönhatásáról, akár nem állami szereplők közötti interakcióról. Megítélésem szerint a disszertáció azzal járult hozzá a nemzetközi kapcsolatok magyar szakirodalmának bővüléséhez, hogy összegezte a nem állami szereplők befolyására vonatkozó eredményeket, és a különböző nem állami szereplöket egységes megközelítésben vizsgálta. Meghaladta a kizárólag egyes szereplőkre vonatkozó esettanulmányokat - bár felhasználta azokat -, és a rendszer egészét, valamint a nem állami szereplők képességeit és számszerü változását a kutatás középpontjába állítva megmutatta, hogy a 21. század nemzetközi, illetve transznacionális kapcsolatainak elemzésekor milyen új megközelítést érdemes alkalmazni, és milyen szereplőkre kell a korábbinál nagyobb figyelmet fordítani. 


\section{IRODALOMJEGYZÉK}

Alston, Philip (2005, szerk.): Non-state actors and human rights. Oxford University Press, New York

Altman, Roger C. (2009): The Great Crash, 2008: A Geopolitical Setback for the West. Foreign Affairs, 88:1, pp. 2-14.

Andreopoulus, George - Arat, Zehra F. Kabasakal - Juviler, Peter (2006): Non-State Actors in the Human Rights Universe. Kumarian Press, Inc., Sterling

Applebaum, Binyamin - Dash, Eric (2011): S\&P downgrades debt rating of U.S. for the first time. The New York Times, 2011. augusztus 6. p. 1.

Armstrong, David (1997): Globalization and the social state. Review of International Studies, 24:4, pp. 461-478.

Arts, Bas (2003): Non-State Actors in Global Governance Three Faces of Power. MaxPlanck-Projektgruppe Recht der Gemeinschaftsgüter, Bonn

Bacevich, Andrew J. (2008): The Limits of Power. Metropolitan Books, Henry Holt and Company, New York

Barnet, Richard - Kavanagh, John (1994): Global Dreams. Simon \& Schuster, New York

Barstow, David (2004): Security Companies: Shadow Soldiers in Iraq. New York Times, 2004. április 19.

Bernstein, Steven - Cashore, Benjamin (2007): Can non-state global governance be legitimate? An analytical framework. Regulation \& Governance, 1:4, pp. 347-371.

Bíró, Gáspár (1998): Bevezetés a nemzetközi politikai viszonyok tanulmányozásába. Teleki László Alapítvány, Budapest

Blahó, András - Prandler, Árpád (2005): Nemzetközi szervezetek és intézmények. Aula Kiadó, Budapest 
Bloodgood, Elizabeth (2011): The Yearbook of International Organizations and Quantitative Non-State Actor Research. In: Reinalda, Bob (2011, szerk.): The Ashgate Research Companion to Non-State Actors. Ashgate, Radbound University, Nijmegen, pp. 19-35.

Bokorné, Szegő Hanna (1999): Nemzetközi jog. Aula Kiadó, Budapest

Cakmak, Cenap (2004): The role of non-governmental organizations (NGOs) in the norm creation process in the field of human rights. Turkish Journal of International Relations, 3:1, pp. 100-122.

Cerny, Philip G. (1995): Globalization and the changing logic of collective action. International Organizations, 49, pp. 595-625.

Charnovitz, Steve (2004): The WTO and cosmopolitics. Journal of International Economic Law, 7:3, pp. 675-682.

Chilton, Patricia (1995): Mechanics of change: Social Movements, Transnational Coalitions, and the Transformation Process in Eastern Europe. In: Risse-Kappen, Thomas (1995, szerk.): Bringing Transnational Relations Back In. Cambridge University Press, Cambridge, pp. 189-226.

Clarke, Michael (2000): French and British security: mirror image sin a globalized world. International Affairs, 76:4, pp. 725-739.

Clausewicz, Carl von (1976): On War. Princeton University Press, Princeton

Coker, Christopher (2001): Outsourcing War. In: Josselin, Daphné - Wallace, William (2001): Non-State Actors in World Politics. Palgrave, New York, 189-202.

Cook, Helena (1996): Amnesty International and the United Nations. In: Willetts, Peter (1996, szerk.): The consciousness of the world: the influence of non-governmental organisations in the UN system. Hurst \& Company, London, pp. 181-213.

Cox, Robert W. (1999): Civil Society at the turn of the Millennium: prospects for an alternative world order. Review of International Studies, 25:1, pp. 3-28. 
Czempiel, Ernst-Otto (1969, szerk.): Die anachronistische Souveranitat. Westdeutcher Verlag, Cologne-Opladen

Dahl, Robert A. (1961): Who Governs? Democracy and Power in an American City. Yale University Press, New Haven

Dakowska, Dorota - Tulmets, Elsa (2007): Transnational relations and foreign policies. In: Le Gloannec, Anne-Marie (2007, szerk.): Non-state Actors in International Relations. The case of Germany. Manchester University Press, Manchester and Palgrave, New York

Della Porta, Donatello - Tarrow, Sidney (2004, szerk.): Transnational Protest and Global Activism. Rowman and Littlefield, Lanham

De Wilde, Jaap (1991): Saved from Oblivion: Interdependence Theory in the First Half of the 20th Century. Aldershot, Dartmouth

Dinh, Nguyen Quoc - Daillier, Patrick - Pellet, Alain - Kovács, Péter (1997): Nemzetközi közjog. Osiris Kiadó, Budapest

Doyle, Michael W. (1983): Kant, Liberal Legacies, and Foreign Affairs. Part 1. Philosophy\&Public Affairs, 12:3, pp. 205-232.

Galló, Béla (1994): A „túlélés tudománya”? Gondolatok a nemzetközi viszonyok elméletéröl. Szociológiai Szemle, 94:1, pp. 91-114.

Gelb, Leslie H. (2009): Necessity, Choice and Common Sense. Foreign Affairs, 88:3, pp. 56-72.

Gelb, Leslie H. (2010): GDP Now Matters More Than Force. Foreign Affairs, 89:6, pp. $35-43$.

Gilpin, Robert (1981): War and Change in World Politics. Cambridge University Press, New York

Gilpin, Robert (2004): Nemzetközi politikai gazdaságtan. BUCIPE, Budapest 
Glenn, John (2009): Welfare Spending in an Era of Globalization: The North-South Divide. International Relations, SAGE Publications, Washington, D.C., 23:1, pp. $27-50$.

Goetz, Klaus H. - Mair, Peter - Smith, Gordon (2010, szerk.): European Politics. Pasts, presents, futures. Routledge, London - New York

Gömbös, Ervin (2011): Az ENSZ és az Európai Unió együttmüködése a lisszaboni szerződés tükrében. Külügyi Szemle, 10:1, pp. 135-154.

Guest, Robert (2011): Borderless Economics. Palgrave Macmillan, London

Haas, Peter (1990): Saving the Mediterranean. Columbia University Press, New York

Hannon, Paul (2011): The Ins and Outs of Future European Integration. Wall Street Journal, 2011. november 1.

He, Baogang - Murphy, Hannan (2007): Global social justice at the WTO? The role of NGOs in constructing global social contracts. International Affairs, 83:4, pp. 707727.

Held, David (1995): Democracy and the Global Order: From the Modern State to Cosmopolitan Governance. Polity, Cambridge

Holliday, Fred (2001): The Romance of Non-state Actors. In: Josselin, Daphné Wallace, William (2001): Non-State Actors in World Politics. Palgrave, New York

Horváth, Jenő (2007): A hidegháború vége. In: Rada, Csaba (2007, szerk.): Új világrend? Nemzetközi kapcsolatok a hidegháború utáni világban. Corvinus Külügyi és Kulturális Egyesület Ifjú Közgazdászok Közhasznú Egyesülete, Budapest

Huntington, Samuel P. (1973): Transnational Organizations in World Politics. World Politics, 25:3, pp. 333-368.

International Organization for Migration (2010): World Migration Report 2010 - The Future of Migration: Building Capacities for Change 
http://publications.iom.int/bookstore/free/WMR_2010_English.pdf

Letöltve: 2011.09.06.

Job, Brian (1992, szerk.): The Insecurity Dilemma. Lynne Rienner, Boulder

Josselin, Daphné - Wallace, William (2001): Non-State Actors in World Politics. Palgrave, New York

Jordán, Gyula (2007): Az új főszereplő: Kína. In: Rada, Csaba (2007, szerk.): Új világrend? Nemzetközi kapcsolatok a hidegháború utáni világban. Corvinus Külügyi és Kulturális Egyesület Ifjú Közgazdászok Közhasznú Egyesülete, Budapest

Kaiser, Karl (1969): Transnationale Politik. In: Czempiel, Ernst-Otto (1969, szerk.): Die anachronistische Souveranitat. Westdeutcher Verlag, Cologne-Opladen

Keck, M. E. és K. Sikkink (1998): Activists beyond borders: advocacy networks in international politics. Cornell University Press, New York

Kelly, Paul (2003): Power Pact. The Australian, 2003. július 26.

Keohane, Robert O. - Nye, J.S. Jr. (1972, szerk.): Transnational Relations in World Politics. Harvard University Press, Cambridge

Keohane, Robert O. - Nye, Joseph S. Jr. (1977): Power and Interdependence. World Politics in Transition. Little, Brown and Company, Boston-Toronto

Keohane, Robert O. (1989): International Institutions and State Power. Westview, Boulder

Keohane, Robert O. (1998): International Institutions: Can Interdependence Work? Foreign Policy, 110, pp. 82-94.

Keohane, Robert O. (2002): Ironies of Sovereignty: The European Union and the United States. Journal of Common Market Studies, 40:4, pp. 743-765.

Khanna, Parag (2009): The Next Big Thing: Neomedievalism. Foreign Policy, http:/www.foreignpolicy.com/articles/2009/04/15/the_next_big_thing_neomediev alism Letöltve: 2012. február 19. 
Kiss J., László (2002): A külpolitika vége? Avagy a kül- és biztonságpolitika új modellje. Külügy Szemle, 1:1, pp. 5-39.

Kiss J., László (2003, szerk.): Globalizálódás és külpolitika. Nemzetközi rendszer és elmélet az ezredfordulón. Teleki László Alapítvány, Budapest

Kiss J., László (2009): Változó utak a külpolitika elméletében és elemzésében. Osiris Kiadó, Budapest

Kissinger, Henry (2001): America at the Apex. Empire or Leader. The National Interest, http://nationalinterest.org/article/america-at-the-apex-1196 Leöltve 2012. február 19.

Kobrin, Stephen J. (1998): Back to the Future: Neomedievalism and the Postmodern Digital World Economy. Journal of International Affairs, 51:2, pp. 361-386.

Korey, William (1998): NGOs and the Universal Declaration of Human Rights. Palgrave, New York

Krasner, Stephen D. (1995): Power politics, institutions, and transnational relations. In: Risse-Kappen, Thomas (1995, szerk.): Bringing Transnational Relations Back In. Cambridge University Press, Cambridge

Le Gloannec, Anne-Marie (2007, szerk.): Non-state Actors in International Relations. The case of Germany. Manchester University Press, Manchester and Palgrave, New York

Lord, Janet E. (2004): Mirror, Mirror on the Wall: Voice Accountability and NGOs in Human Rights Standard Setting. Seton Hall Journal of Diplomacy and International Relations, 5, pp. 93-110.

Magone, José (2011): Contemporary European Politics. A comparative introduction. Routledge, London - New York

Mansbach, Richard W. - Vasquez, John A. (1981): In Search of Theory: A New Paradigm for Global politics. Columbia University Press, New York 
Martens, Kerstin (2000): NGO Participation in International Conferences: Assessing Theoretical Accounts. Transnational Assosiations, 3, pp. 115-127.

Mathews, Jessica T. (1997): Power shift. Foreign Affairs, 76:1, pp. 50-66.

Mearsheimer, John (2001): The Tragedy of Great Power Politics. W.W. Norton \& Company, New York

Mearsheimer, John (2011): Why Leaders Lie. Oxford University Press, Oxford

Minc, Alain (1993): Le nouveau Moyen Age. Gallimard, Paris

Moravcsik, Andrew (1997): Taking Preferences Seriously: A Liberal Theory of International Politics. International Organization, 51:4, pp. 513-553.

Morgenthau, Hans J. (2005): Politics among Nations. McGraw-Hill Companies, New York

Morgenthau, Hans J. (2009): Six principles of political realism. In: Art, Robert J. Jervis, Robert (2009, szerk.): International politics. Pearson, Longman

Mosley, Layna (2005): Globalisation and the State: Still Room to Move? New Political Economy, 10:3, pp. 355-363.

Náray, Péter (2003): Invest in Business Advocacy for WTO Negotiations. International Trade Forum 2., április-június

Nossel, Suzanne (2004): Smart Power. Foreign Affairs, 83:2, pp. 131-142.

Nye, Joseph S. Jr (1990): The Changing Nature of World Power. Political Science Quarterly, 105:2, pp. 177-192.

Nye, Joseph S. Jr. (2004a): Soft Power. The Means to Success in World Politics. Public Affairs, New York

Nye, Joseph S. Jr. (2004b): Soft Power and American Foreign Policy. Political Science Quarterly, 119:2, pp. 255-270. 
Nye, Joseph S. Jr. (2006a): Think Again: Soft Power. Foreign Policy, 2006. február 23. http://www.foreignpolicy.com/articles/2006/02/22/think_again_soft_power, Letöltve: 2012. február 12.

Nye, Joseph S. Jr. (2006b): Smart Power: In Search of the Balance between Hard and Soft Power. Democracy: A Journal of Ideas,

http://www.democracyjournal.org/2/6491.php?page=all Letöltve: 2012. február 19.

Nye, Joseph S. Jr. (2011): The Future of Power. Public Affairs, New York

O’Brien, Robert J. - Goetz, Anne Marie - Scholte, Jan Aart - Williams, Marc A. (2000): Contesting global governance: multilateral economic institutions and global social movements. Cambridge University Press, Cambridge

Osborne, David - Gaebler, Ted (1992): Reinventing Government. Penguin, Reading

Perkins, Wenchi Yu (2005): Vital Voices: Advocacy and Service Work of NGOs in the Fight Against Human Trafficking. UN Chronicle, 42:1, pp. 54-56.

Rawi, Abdelal - Adam, Segal (2007): Has Globalization Passed Its Peak? Foreign Affairs, 86:1, pp. 103-114.

Reinalda, Bob (2011, szerk.): The Ashgate Research Companion to Non-State Actors. Ashgate, Radbound University, Nijmegen

Reinicke, Wolfgang H. (1998): Global Public Policy: Governing Without Government? Brookings Institution, Washington, D.C.

Reinisch, August (2005): The Changing International Legal Framework for Dealing with Non-State Actors. In: Alston, Philip (2005, szerk.): Non-State Actors and Human Rights. Oxford University Press, New York, pp. 37-89.

Risse-Kappen, Thomas (1995, szerk.): Bringing Transnational Relations Back In. Cambridge University Press, Cambridge

Risse, Thomas (2000): The Power of Norms versus the Norms of Power: Transnational Civil Society and Human Rights. In: Ann M. Florini (2000, szerk.): The Third Force. The Rise of Transnational Civil Society. Japan Centre for International 
Exchange, Tokyo, Carnegie Endowment for International Peace, Washington, D.C. pp. 177-210.

Rochon, Thomas (1988): Mobilizing for Peace: The Anti-Nuclear Movement in Western Europe. Princeton University Press, Princeton

Rosenau, Pauline Vaillancourt (2000, szerk.): Public-Private Policy Partnerships. MIT Press, Cambridge

Rosenau, James (1980): The Study of Global Independence. Pinter, London

Rosenau, James (1990): Turbulence in World Politics. Princeton University Press, Princeton

Ruggie, John (2004): Reconstituting the Global Public Domain - Issues, Actors and Practices. European Journal of International Relations, 2004:10, pp. 499-531.

Schechter, Michael G. (1999, szerk.): The Revival of Civil Society. Macmillan, London

Shaw, Martin (1991): Post-military Society. Polity Press, Cambridge

Simon, Zoltán (2009): Érdekérvényesités a közpolitikai döntéshozatalban az Európai Unióban és Magyarországon. L’Harmattan Kiadó, Budapest

Slaughter, Anne-Marie (1997): The Real New World Order. Foreign Affairs, 76:5, pp. 183-197.

Slaughter, Anne-Marie (2009): America's Edge: Power in the Networked Century. Foreign Affairs, 88:1, pp. 94-113.

Steiner, Henry J. - Alston, Philip (1996): International Human Rights in Context: Law, Politics, Morals. Clarendon Press, Oxford

Strange, Susan (1996): The Retreat of the State: the Diffusion of Power in the World Economy. Cambridge University Press, New York

Szabó, Máté (2003): Civil Society and Security reform in Hungary. Central European Political Science Review, 4, pp. 6-34. 
Szentes, Tamás (2005): Világgazdaságtan I. Elméleti és módszertani alapok. Aula Kiadó, Budapest

Szörényi, András (2009): Smart power, avagy az év „felfedezése”. Külügyi Szemle, 8:3, pp. 147-158.

Thompson, Joseph E. (2002): Virtual Regime: A New Actor in the Geopolitical Arena. Political Science and Politics, 35:3, pp. 503-524.

Törő, Csaba (2000): Nem kormányzati szervezetek nemzetközi kapcsolatai - „Civil diplomácia”. In: Nyusztay, László dr. (2000, szerk.): Szakdiplomáciai tanulmányok. Budapesti Gazdasági Főiskola Külkereskedelmi Főiskolai Kar, Budapest

Trivett, Vincent (2011): 25 US Mega Corporations: Where They Rank If They Were $\begin{array}{llll}\text { Countries. } & \text { Businessinsider.com, június } 271 .\end{array}$ http://www.businessinsider.com/25-corporations-bigger-tan-countries-20116?op=1\#ixzz2HntiAnAh Letöltve: 2013. január 12.

UN report (2004): We the peoples: civil society, the United Nations and global governance. Report of the Panel of Eminent Persons on United Nations Civil Society Relations http://www.unccd.int/cso/docs/a58_817.pdf Letöltve: 2012. február 19.

UNGA (2004): Strengthening of the United Nations system. Fifty-eighth session, Agenda item 59. 2004. június 11.

Van Creveld, Martin (1991): On Future War. Brassey's, London

Vogel, David (2005): The Market for Virtue: the potential and limits of Corporate Social Responsibility. Brookings, Washington, D.C.

Walt, Stephen M. (2011): The Myth of American Exceptionalism. Foreign Policy, 2011. október 11 .

www.foreignpolicy.com/articles/2011/10/11/the_myth_of_american_exceptionalis m Letöltve: 2011. november 12. 
Walter, Andrew (2001): Unravelling the Faustian Bargain: Non-state Actors and the Multilateral Agreement on Investment. In: Josselin, Daphné - Wallace, William (2001): Non-State Actors in World Politics. Palgrave, New York

Waltz, Kenneth N. (1979): Theory of International Politics. McGraw-Hill Inc., New York

Waltz, Kenneth N. (2009): The Anarchic Structure of World Politics. In: Art, Robert J Jervis, Robert (2009): International Politics. Pearson, Longman

Webb, Kernaghan (2002): Voluntary Codes: Private governance, the public interest and innovation. Carleton University, Ottawa

Welling, J. J. (2007): Non-governmental Organisations, Prevention and Intervention in Internal Conflict: Through the Lens of Darfur. Indiana Journal of Global Legal Studies, 14:1, pp. 147-178.

Wilson, Ernest J. (2008): Hard Power, Soft Power, Smart Power. The Annals of the American Academy of Political and Social Science, 616, pp. 110-124.

Willetts, Peter (1982): Pressure Groups in the Global System. Pinter, London

Willetts, Peter (2006): What is a non governmental organisation? UNESCO Encyclopaedia of Life Support Systems, http://www.staff.city.ac.uk/p.willets/CSNTWKS/NGO-ART.htm, Letöltve: 2010. április 22.

\section{Internetes források}

Facebook user growth, http://www.tecca.com/news/2011/07/06/facebook-has-750-million-users-graph/ Letöltve: 2012. január 15.

Global map of social networking 2011, http://www.marketingonline.co.uk/wiki/File:GlobalSocialMediaUsage.png, Letöltve: 2012. január 15.

http://www.amnesty.hu/content.php?oldall=1

http://www.coe.int 
http://www.europa.eu

http://www.ec.europa.eu

http://www.loc.gov

http://www.un.org

http://www.wcd.coe.int 


\section{A TÉMAKÖRREL KAPCSOLATOS PUBLIKÁCIÓK}

Könyv - könyvrészlet:

1) Rónay, Miklós - Szörényi, András (2010, szerk.): Elnökségi munka az Európai Unióban. Gondolat Kiadó, Budapest, p. 270.

2) Szörényi, András (2013): A Tanács. In: Simon, Zoltán (2013, szerk.): Döntéshozatal és Jogalkotás az Európai Unióban. L’Harmattan kiadó, Budapest, pp. 284-314.

3) Korányi, Dávid - Szörényi, András (2013): Az Európai Tanács. In: Simon, Zoltán (2013, szerk.): Döntéshozatal és Jogalkotás az Európai Unióban. L'Harmattan kiadó, Budapest, pp. 207-223.

4) Szörényi, András (2010): Az Európai Unió görög elnöksége. In: Rónay, Miklós - Szörényi, András (2010, szerk.): Elnökségi munka az Európai Unióban. Gondolat Kiadó, Budapest, pp. 32-45.

5) Kozenkow, Judit - Szörényi, András (2010): Kihívásokkal szembesülő svéd elnökség. In: Rónay, Miklós - Szörényi, András (2010, szerk.): Elnökségi munka az Európai Unióban. Gondolat Kiadó, Budapest, pp. 217-230.

6) Szörényi, András (2009): A nem állami szereplők befolyásának növekedése és ennek hatása az Európai Unió döntéshozatali mechanizmusára. In: Palánkai, Tibor (2009): Tanulmányok az európai integráció témaköréböl. Savaria University Press, Szombathely. pp. 65-76.

Folyóiratcikk:

7) Kozenkow, Judit - Szörényi, András (2012): Do elections lead to successful transition in the Arab Spring countries? Center for Transatlantic Relations, SAIS, Johns Hopkins University. 2012/5 http://transatlantic.saisjhu.edu/publications/articles/Judit_Kozenkow_and_Andras_Szorenyi_Do_elec tions_lead_to_successful_transition_in_the_Arab_Spring_countries.pdf, JHUSAIS, Washington

8) Szörényi, András (2010): A társadalmi diplomácia (public diplomacy) újraértelmezése a 21. században. Külügyi Szemle, 2010/4. pp. 137-157. 
9) Szörényi, András (2010): Nemzeti Alapítvány a Demokráciáért / National Endowment for Democracy. Grotius, 2010, http://www.grotius.hu/publ/displ.asp?id=OGOCYU

10) Szörényi, András (2009): Smart power, avagy az év „felfedezése”. Külügyi Szemle, 2009/3. pp. 147-158.

11) Szörényi, András (2009): A nem állami szereplők befolyása a multilaterális diplomáciára. Föld-rész, 2009/2. Budapest, L’Harmattan kiadó pp. 54-64.

12) Szörényi, András (2009): A nem állami szereplők befolyásának növekedése a nemzetközi szervezetekre. Tudományos Közlemények, 2009. április, Budapest, ÁVF pp. 61-68.

13) Szörényi, András (2009): Kiindulópontok a nemzetközi kapcsolatok elméletében a nem állami szereplők természetének és szerepének értelmezéséhez. Grotius, 2009, http://www.grotius.hu/publ/displ.asp?id=DLNNSK

14) Szörényi, András (2006): La politique étrangère hongroise au début d'une nouvelle phase. Revue internationale et stratégique, 2006/1:61. Dalloz, Paris pp. 37-48. 